\title{
Fine particle flotation for Florida dolomitic phosphate pebbles
}

\author{
Zhengxing Gu \\ West Virginia University
}

Follow this and additional works at: https://researchrepository.wvu.edu/etd

\section{Recommended Citation}

Gu, Zhengxing, "Fine particle flotation for Florida dolomitic phosphate pebbles" (2002). Graduate Theses, Dissertations, and Problem Reports. 1251.

https://researchrepository.wvu.edu/etd/1251

This Thesis is protected by copyright and/or related rights. It has been brought to you by the The Research Repository @ WVU with permission from the rights-holder(s). You are free to use this Thesis in any way that is permitted by the copyright and related rights legislation that applies to your use. For other uses you must obtain permission from the rights-holder(s) directly, unless additional rights are indicated by a Creative Commons license in the record and/ or on the work itself. This Thesis has been accepted for inclusion in WVU Graduate Theses, Dissertations, and Problem Reports collection by an authorized administrator of The Research Repository @ WVU. For more information, please contact researchrepository@mail.wvu.edu. 


\title{
Fine Particle Flotation for Florida Dolomitic Phosphate Pebbles
}

\author{
Zhengxing Gu
}

Thesis submitted to

College of Engineering and Mineral Resources

at West Virginia University

in partial fulfillment of the requirements

for the degree of

\author{
Master of Science \\ in \\ Mining Engineering
}

Felicia F. Peng, Ph.D., Chair

Eung Ha Cho, Ph.D.

Li Luo, Ph.D.

Department of Mining Engineering

Morgantown, West Virginia

2002

Keywords: collector, dolomitic phosphate, liberation, grade, recovery, flotation rate 


\section{ABSTRACT \\ Fine Particle Flotation for Florida Dolomitic Phosphate Pebbles Zhengxing Gu}

A Florida dolomitic phosphate pebble sample was processed using a 1.2 liter stirrertank flotation cell and 2-in ID packed flotation column aiming at achieving a phosphate concentrate containing more than $30 \% \mathrm{P}_{2} \mathrm{O}_{5}$ and less than $1.0 \% \mathrm{MgO}$ contents at high $\mathrm{P}_{2} \mathrm{O}_{5}$ recovery.

The characteristics of fatty acid collector, FA-12 and a newly developed PA-31 collector were evaluated for frothability and dolomite flotation rate. The evaluation results show that both reagents have high frothability, but PA-31 has much stronger frothability than FA-12, and higher selectivity in separating dolomite from phosphate mineral.

The mineralogical study indicates that the phosphate pebble sample needs to be ground to minus $150 \mu \mathrm{m}(-100 \mathrm{mesh})$ for liberation of dolomite from phosphate. For the stirrer-tank cell, the composite phosphate concentrate has $31.66 \% \mathrm{P}_{2} \mathrm{O}_{5}$ and $0.79 \% \mathrm{MgO}$ at the overall $\mathrm{P}_{2} \mathrm{O}_{5}$ recovery of $92 \%$. For packed column flotation, the composite phosphate concentrate has $30 \% \mathrm{P}_{2} \mathrm{O}_{5}$ and $0.96 \% \mathrm{MgO}$ at the overall $\mathrm{P}_{2} \mathrm{O}_{5}$ recovery of $91 \%$. 


\section{ACKNOWLEDGEMENTS}

The author would like to express his deep appreciation to his academic advisor and thesis committee Chair, Dr. Felicia F. Peng for her persistent guidance and encouragement during the course of the research work. The valuable suggestions and comments by the thesis committee member, Dr. Eung Ha Cho and Dr. Yi Luo are greatly appreciated.

The author would also like to express his sincere thanks to his former advisor, Dr. David C. Yang for his support and guidance for starting up this research. Dr. Patrick Zhang, the research director of Florida Institute of Phosphate Research, is acknowledged for his assistance in phosphate sample acquisition and analysis. Without his special support, the present work could not be completed in timely fashion.

The financial support of this research provided by Coal and Energy Research Bureau, West Virginia, to the author in pursuing his Master of Science Degree in Engineering Department, College of Engineering and Mineral Resources, West Virginia University is greatly acknowledged.

The author wishes to give particular thanks to his family members in China for their constant encouragement and moral support, and to his wife, Xiaomei Wang and his daughter, Jie Gu for their constant love and understanding. 


\section{TABLE OF CONTENTS}

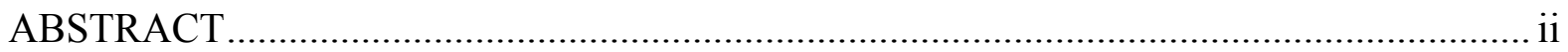

ACKNOWLEDGEMENTS ...................................................................................... ii

TABLE OF CONTENTS ..................................................................................... iv

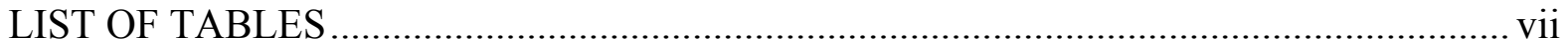

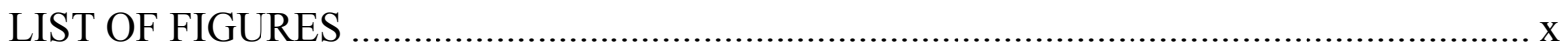

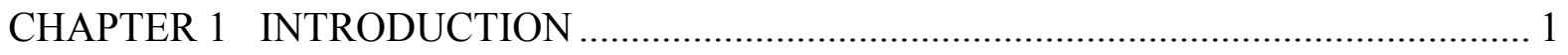

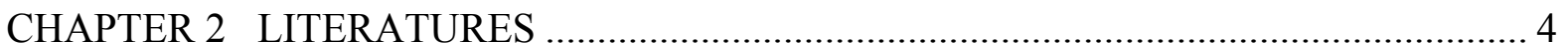

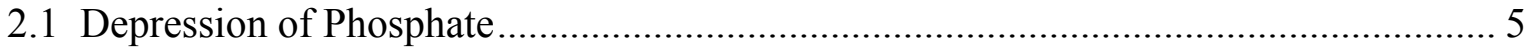

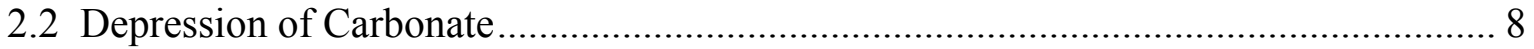

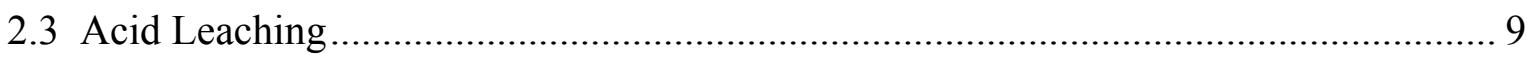

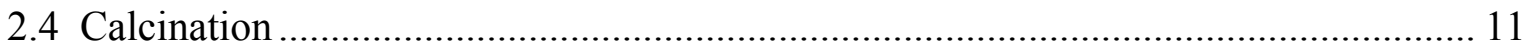

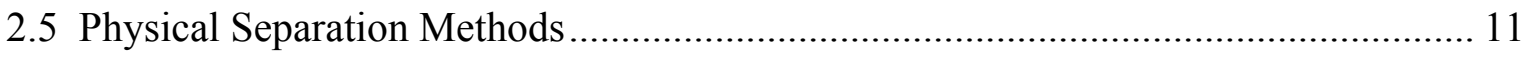

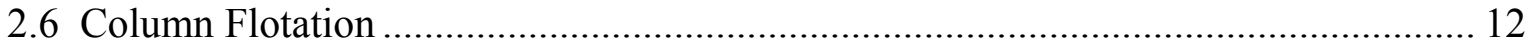

2.7 Other Development ................................................................................... 14

CHAPTER 3 EXPERIMENTS .............................................................................. 16

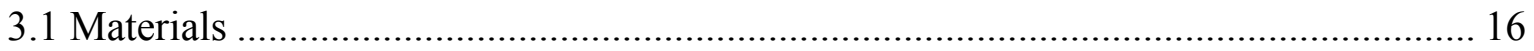

3.1.1 Source of Dolomitic Phosphate Pebble Sample................................................. 16

3.1.2 Characterization of Dolomitic Phosphate Pebble Sample .................................. 17 
3.1.3 Sample Preparation ..................................................................................... 22

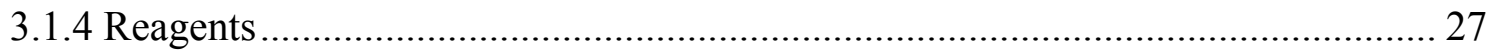

3.2 Apparatus and Procedures............................................................................ 28

3.2.1 Frothability Measurement of Fatty Acids ……….............................................. 28

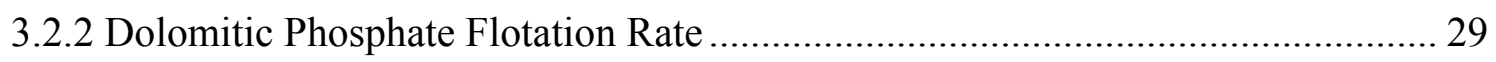

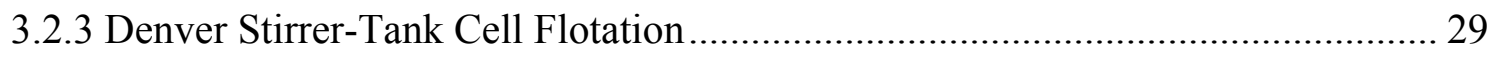

3.2.4 Packed Column Flotation..................................................................................... 30

3.3 Procedures and Instrument Used for Determination of Phosphate and Magnesium .... 34

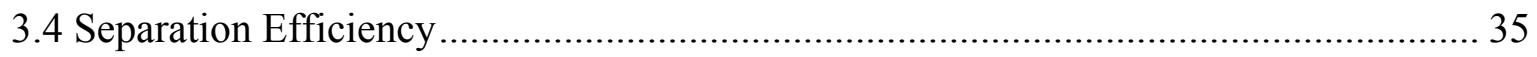

3.5 Experiment Design for Flotation Tests .................................................................... 36

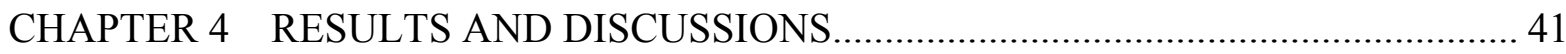

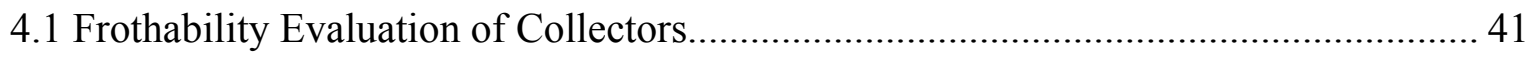

4.2 Flotation Rate of Dolomite Phosphate Flotation ………………................................ 48

4.3 Dolomitic Phosphate Flotation with Denver D-12 Machine and 1.2 Liter Cell ........... 55

4.3.1 Effect of $\mathrm{pH}$

4.3.2 Effect of Collector Dosages on Dolomite Flotation .............................................. 56

4.3.3 Correlation of $\mathrm{MgO}$ Grade and $\mathrm{P}_{2} \mathrm{O}_{5}$ Recovery in Sink Product

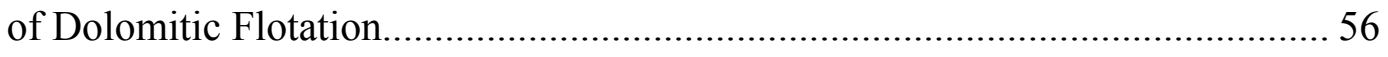

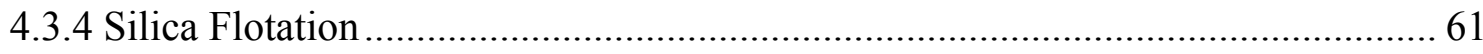

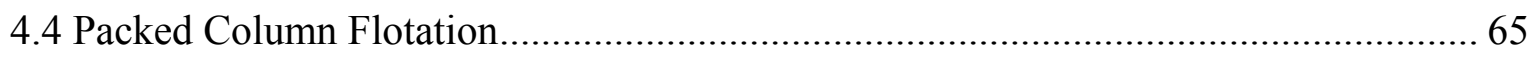

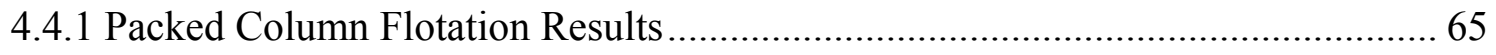

4.4.2 Silica Flotation of Dolomitic Phosphate Flotation Sink ……............................... 70

4.4.3 Comparison of Test Results with Denver D-12 Cell Data..................................... 71 


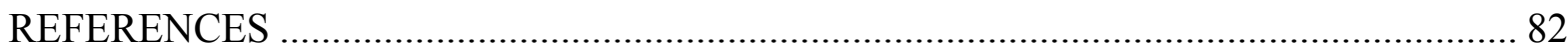

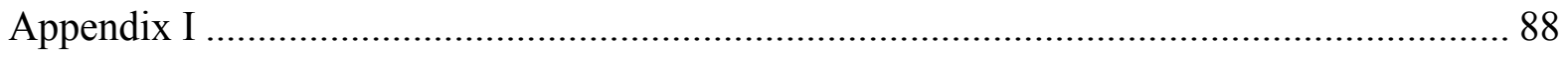

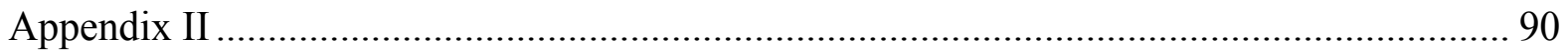

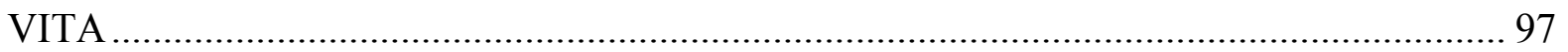




\section{LIST OF TABLES}

Page

Table 1-1 Summary of Processes Developed for Dolomitic Phosphate Beneficiation ........ 2

Table 3-1 Chemical Analysis of Dolomitic Phosphate Pebble Sample............................. 17

Table 3-2 Size Distribution and Chemical Assay of Each Size Fraction for

Dolomitic Phosphate Pebble Sample ................................................................. 18

Table 3-3 Size Distribution and Chemical Assay of Each Size Fraction for Dolomitic

Phosphate Pebble Sample after Rejecting Minus 0.1 mm Size Fraction........... 20

Table 3-4 Unit Cell Parameters, Refractive Index and Specific Gravity of Phosphate

Mineral in Dolomitic Phosphate Pebble Sample …………………………...... 21

Table 3-5 Mineral Composition of As-Received Dolomitic Phosphate Pebble Sample .... 21

Table 3-6 Percentage of Liberated Phosphate Mineral in Different Size Fractions ........... 23

Table 3-7 Size Distribution of Florida Dolomitic Pebble Sample after

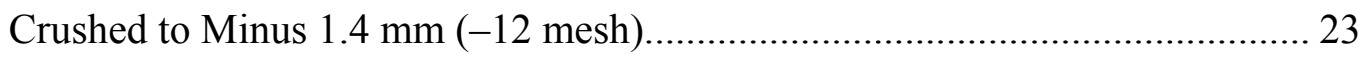

Table 3-8 Stainless Steel Rods as Grinding Media for the Milling Experiment ................. 25

Table 3-9 Size Distribution at Different Grinding Time for $300 \mathrm{~g}$ Dolomitic

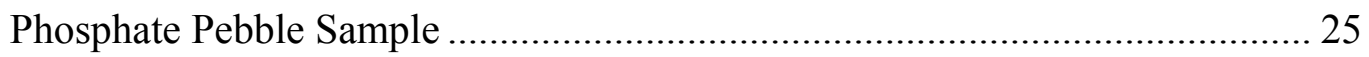

Table 3-10 Size Distribution at Different Grinding Time for $1000 \mathrm{~g}$ Dolomitic

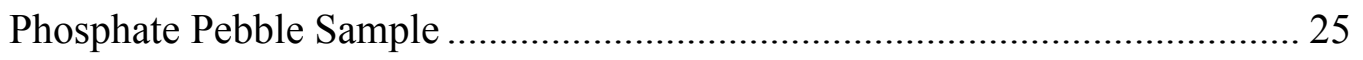

Table 3-11 Factors and Levels for the First Set of Test Runs .............................................. 39

Table 3-12 Experiment Design for the First Set of Test Runs............................................. 39

Table 3-13 Factors and Levels for the Second Set of Test Runs .......................................... 40 
Table 3-14 Experiment Design for the Second Set of Test Runs

Table 4-1 Ultimate Froth Height and Volume Constant as a Function of Froth

Concentration..... 46

Table 4-2 Size Distribution and Chemical Analysis of Flotation Feed........ 50

Table 4-3 Parameters of Dolomitic Phosphate Pebble Flotation Rate

Models for MgO Recovery 50

Table 4-4 pH Effect on Dolomitic Phosphate Flotation Using Denver

D-12 Machine and 1.2 Liter Cell 57

Table 4-5 Collector Dosage Effect on Dolomitic Phosphate Flotation

Using Denver D-12 Machine and 1.2 Liter Cell.....

Table 4-6 Size Distribution and Chemical Analysis of the Sink Product of

Dolomitic Phosphate Flotation

Table 4-7 Material Balance of Dolomitic Phosphate Flotation and

Amine Flotation Using Denver Stirrer Tank Cell 64

Table 4-8 Dolomitic Phosphate Flotation Results Based on Factorial

Design I, Step-one Experiment 67

Table 4-9 Main Effects of the Factors for Factorial Design I, Step-one Experiment........ 68

Table 4-10 Levels of the Factors Used in Factorial Design I, Step-two Experiment .......... 72

Table 4-11 Experiment Design for Factorial Design I, Step-two Experiment ................... 72

Table 4-12 Dolomitic Phosphate Flotation Results Using Packed Flotation Column

Based on Factorial Design I, Step-two Experiment 73

Table 4-13 Main Effects of the Factors Using $\mathrm{SI}_{\mathrm{p}}$ as Response for Factorial

Design I, Step-two Test. 74 
Table 4-14 Dolomitic Phosphate Flotation Results Using Packed Flotation Column Based on Factorial Design II......................................................................... 75

Table 4-15 Main Effects of the Factors Using $\mathrm{SI}_{\mathrm{p}}$ as Response

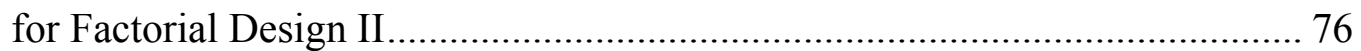

Table 4-16 Material Balance of Dolomitic Phosphate Flotation and Silica Flotation.......... 76 


\section{LIST OF FIGURES}

Page

Figure 3-1 Percent Passing as a Function of Grinding Time for $300 \mathrm{~g}$ Sample ................. 26

Figure 3-2 Percent Passing as a Function of Grinding Time for $1000 \mathrm{~g}$ Sample ............... 26

Figure 3-3 Procedures for Processing Florida Dolomitic Phosphate Pebble Sample ........... 31

Figure 3-4 Schematic Diagram of 2-in ID Packed Flotation Column System ................... 32

Figure 4-1 Froth Height as a Function of Aeration Rate at Various FA-12 Dosages.......... 42

Figure 4-2 Froth Height as a Function of Aeration Rate at Various PA-31 Dosages.......... 43

Figure 4-3 Initial Retention Time as a Function of Collector Concentration ..................... 47

Figure 4-4 MgO Recovery as a Function of Time at Various FA-12 Collector Dosages .... 52

Figure 4-5 MgO Recovery as a Function of Time at Various PA-31 Collector Dosages .... 52

Figure 4-6 Dolomite Flotation Rate Comparison with FA-12 and PA-31 Collector

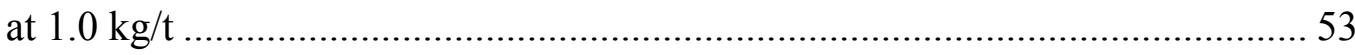

Figure 4-7 $\quad \mathrm{P}_{2} \mathrm{O}_{5}$ Recovery in Dolomite Float as a Function of Flotation Time

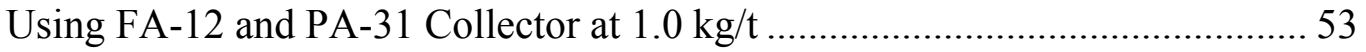

Figure 4-8 $\quad \mathrm{P}_{2} \mathrm{O}_{5}$ Recovery in Sink Product as a Function of Flotation Time ..................... 54

Figure 4-9 $\mathrm{MgO}$ and $\mathrm{P}_{2} \mathrm{O}_{5}$ Grade in the Sink Product as a Function of Flotation

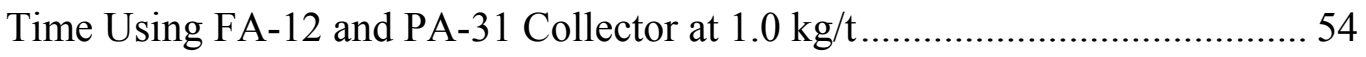

Figure 4-10 Effect of Flotation $\mathrm{pH}$ on the Recovery and Grade of $\mathrm{P}_{2} \mathrm{O}_{5}$ and $\mathrm{MgO}$ in Concentrate (Sink Product).......................................................... 58

Figure 4-11 Effect of Collector Dosages on Dolomite Flotation Performance .................. 60 
Figure 4-12 Relationship between $\mathrm{MgO}$ and $\mathrm{P}_{2} \mathrm{O}_{5}$ Grade and $\mathrm{P}_{2} \mathrm{O}_{5}$ Recovery in the Sink Product of Dolomitic Phosphate Flotation

Figure 4-13 Normal Probability Plot of Effect Estimates for Factorial

Design I, Step-one Experiment. 68

Figure 4-14 Relationship between $\mathrm{MgO}$ and $\mathrm{P}_{2} \mathrm{O}_{5}$ Grades and $\mathrm{P}_{2} \mathrm{O}_{5}$ Recovery in the Sink Product of Dolomitic Phosphate Flotation Using Denver Cell and Packed Column. 77 


\section{CHAPTER 1 INTRODUCTION}

Phosphate rock, as a primary source of phosphorous in fertilizers, represents a vital non-renewable resource. This commodity is neither substitutable nor recyclable in agricultural applications. Hence, total demand must be met through the mining, beneficiation and processing of naturally derived materials (Stowasser, 1980). Approximately, 150 million tons of phosphate concentrate is produced each year worldwide. Among this phosphate production, about $90 \%$ is used for manufacturing phosphate-bearing fertilizers, $4 \%$ for feed supplements, $4 \%$ for detergent and remaining part for other utilization.

Florida is rich in phosphate resources. Its annual phosphate production accounts for one third of the total output of the world. The easily-beneficiated and high-grade siliceous phosphate ore from the Bone Valley Formation is being depleted rapidly. It is estimated that the Florida phosphate reserve that could be economically processed with the available phosphate beneficiation technology could last only about 20 years at the current mining rate. As the phosphate mining operation is moving south and southeast of Florida, the phosphate matrix becomes leaner in phosphate grade and higher in dolomite mineral.

In order to mine and use the dolomitic phosphate resource in the near future to meet the demands on the phosphate products, studies have been carried out on recovering phosphate from Florida dolomitic phosphate ores since 1970s. Some encouraging results have been achieved. The most typical processes include International Mineral \& ChemicalAgrico Company (IMCA) cationic process, Tennessee Valley Authority (TVA) diphosphonic

acid process, University of Florida (UF) two-stage conditioning process, University of 
Alabama (UA) no conditioning process, US Bureau of Mine (USBM) scrubbing and flotation process, etc. In 1990s, Florida Institute of Phosphate Research (FIPR) organized an in-house research project to conduct a comprehensive evaluation on the typical flowsheets available for processing dolomitic phosphate rocks with the results summarized in Table 1-1 (El-Shall, 1996). The table shows that most processes could not produce an acceptable phosphate concentrate with more than $30 \% \mathrm{P}_{2} \mathrm{O}_{5}$ and less than $1 \% \mathrm{MgO}$ except IMCA cationic process. All other processes gave either very low $\mathrm{P}_{2} \mathrm{O}_{5}$ recovery and/or high $\mathrm{MgO}$ in concentrate. It can also be noted that the feed for most of those processes was deslimed at $106 \mu \mathrm{m}(150$ mesh) prior to flotation which should be one of the reasons leading to low $\mathrm{P}_{2} \mathrm{O}_{5}$ recovery of final phosphate concentrate.

Table 1-1 Summary of Processes Developed for Dolomitic Phosphate Beneficiation

\begin{tabular}{|c|c|c|c|c|}
\hline \multirow{2}{*}{$\begin{array}{c}\text { Feed Size } \\
\mu \mathrm{m} \text { (Tyler mesh) }\end{array}$} & \multirow{2}{*}{ Process } & \multicolumn{3}{|c|}{ Concentrate, \% } \\
\cline { 3 - 5 } & & $\mathrm{P}_{2} \mathrm{O}_{5}$ & $\mathrm{MgO}$ & $\begin{array}{c}\mathrm{P}_{2} \mathrm{O}_{5} \\
\text { recovery }\end{array}$ \\
\hline$-425+106(-35+150)$ & IMCA & 31.66 & 0.84 & 58.4 \\
\hline$-600+106(-28+150)$ & USBM & 31.73 & 1.22 & 27.4 \\
\hline$-425+106(-35+150)$ & UF & 28.97 & 0.97 & 27.7 \\
\hline$-300+45(-48+325)$ & TVA & 30.73 & 1.51 & 66.0 \\
\hline$-425+106(-35+150)$ & UA & 26.20 & 1.19 & 87.1 \\
\hline
\end{tabular}

In this study, the Florida dolomitic phosphate pebble sample was processed with the Denver 1.2-liter stirrer flotation cell and the 2-in ID packed flotation column aiming to produce an industrially acceptable phosphate concentrate. There will be no desliming operation in preparing flotation feed in order to achieve high overall $\mathrm{P}_{2} \mathrm{O}_{5}$ recovery.

The objectives of this work are: 1) to study the effect of grinding time on liberation of dolomite; 2) to compare the effectiveness of the conventional fatty acid collector FA-12 with 
that of a newly developed fatty acid collector PA-31 on dolomite flotation; 3) to optimize the operation conditions using a stirrer-tank cell; and 4) to determine the effects of operation conditions of packed flotation column, including, feed solid concentration, $\mathrm{pH}$, collector dosage, air flow rate, wash water and interface (froth height). 


\section{CHAPTER 2 LITERATURES}

Among the impurities in phosphate ores, carbonates such as dolomite, calcite, etc. are most detrimental components that will cause considerable problems in downstream operation. Higher carbonates in phosphate concentrate will result in high sulfuric consumption and high viscosity in phosphoric acid production, which will dramatically increase the operation cost of the process. Separation of dolomite from phosphate has long been recognized as the toughest subject due to various reasons. In dolomitic phosphate ores, the carbonates are disseminated into the phosphate mineral matrix in extremely fine particles, which will require fine grinding to liberate the dolomite. The most important phosphate mineral in industry scale is apatite with the chemical formula of $\mathrm{Ca}_{3}\left(\mathrm{PO}_{4}\right)_{2}$. During the formation of the phosphate ore, different varieties of apatite were formed by partial substitution of phosphate ions of $\mathrm{PO}_{4}{ }^{3-}$ with other component such as $\mathrm{Cl}^{-}, \mathrm{OH}^{-}, \mathrm{CO}^{3-}$, etc., corresponding to chlorapatite, hydrapatite, carbonated apatite, respectively. It can be seen that apatite $\left[\mathrm{Ca}_{3}\left(\mathrm{PO}_{4}\right)_{2}\right]$, dolomite $\left[(\mathrm{Ca}, \mathrm{Mg}) \mathrm{CO}_{3}\right]$ and calcite $\left[\mathrm{CaCO}_{3}\right]$ are all oxide-type minerals with common cation of calcium. Both of them are sparingly water-soluble. When these minerals are in water together with surfactants and modifiers, the complex reaction will take place, such as self-aggregation and precipitation of surfactants, dissolution of solids, hydrolysis/complexation/precipitation of different species. These will lead to difficulties in separating them by flotation process because of the similarities of the adsorption and desorption behaviors of the two types of minerals in the flotation process. Systematic research in carbonate phosphate ore beneficiation started in the early fifties. Since then, 
research efforts in this area have been extensive. The techniques investigated or proposed may be divided into six groups: 1) direct flotation of phosphate with the addition of sodium silicate to depress the carbonate gangue; 2) reverse flotation of the carbonate gangue with depressing the phosphate; 3) rapid change of flotation parameters; 4) physical methods (gravity, attrition, heavy media); 5) calcinations; and 6) acid leaching. Although the first column flotation plant in the world was erected for processing phosphate in 1980's, little progress has been made in application of flotation column in phosphate industry since then, and almost no work has been done in applying flotation column to beneficiating dolomitic phosphate ores.

\subsection{Depression of Phosphate}

The United States Bureau of Mines (USBM) has developed three processes for highdolomite phosphates. There are: 1) flotation of carbonates using a tall oil fatty acid while depressing phosphate using fluosilicic acid; 2) scrubbing-dolomite flotation process; and 3) $\mathrm{SO}_{2}$ Process (Rule et al., 1970, 1974, 1982, 1985). For the fluosilicic acid process using the reagent dosage of $0.7 \mathrm{~kg} / \mathrm{t}$ of fatty acid, $0.45 \mathrm{~kg} / \mathrm{t}$ of $\mathrm{H}_{3} \mathrm{SiFO}_{4}$, a concentrate with $25.5 \% \mathrm{P}_{2} \mathrm{O}_{5}$ and $0.84 \% \mathrm{MgO}$ was obtained at the $\mathrm{P}_{2} \mathrm{O}_{5}$ recovery of $89.5 \%$ from a feed of $20.8 \% \mathrm{P}_{2} \mathrm{O}_{5}$ and $1.1 \% \mathrm{MgO}$. The concentrate grade was, however, not satisfactory.

The efficiency of phosphate depression by fluosilicic acid was also studied by Celerici (1984). Carbonate flotation was carried out at $\mathrm{pH} 6.5$, with $500 \mathrm{~g} / \mathrm{t}$ of tall oil as collector and $300 \mathrm{~g} / \mathrm{t}$ of $\mathrm{H}_{2} \mathrm{SiF}_{6}$ as phosphate depressant. A reasonable grade of concentrate was obtained. However, the overall $\mathrm{P}_{2} \mathrm{O}_{5}$ recovery was less than $28 \%$. 
A study by Atalay and coworkers (1985) indicated that fluosilicic acid was not as efficient as diphosphonic acid or phosphoric acid for depressing a Turkish phosphate ore. The fluosilicic acid process gave a concentrate assayed less than $26 \% \mathrm{P}_{2} \mathrm{O}_{5}$, at $\mathrm{P}_{2} \mathrm{O}_{5}$ recovery below $57 \%$.

Ratobylskaya et al. (1975) found that orthophosphoric acid could increase the surficial solubility of apatite and render it unfit for fatty acid adsorption. Using $6 \mathrm{~kg} / \mathrm{t}$ phosphoric acid and $0.3 \mathrm{~kg} / \mathrm{t}$ fatty acid at $\mathrm{pH} 5$, these investigators were able to recover $75 \%$ of $\mathrm{P}_{2} \mathrm{O}_{5}$ and eliminate most of the carbonate gangue. Carbonate flotation was followed by direct phosphate flotation after increasing the $\mathrm{pH}$ to $7.6-8.0$ using $1.5 \mathrm{~kg} / \mathrm{t}$ caustic soda.

Phosphoric acid was used as an apatite depressant by USBM in separating dolomite from a southern Florida ore (Llewellyn, 1982). However the results were not encouraging. The concentrate containing $27.5 \% \mathrm{P}_{2} \mathrm{O}_{5}, 1.9 \% \mathrm{MgO}$, and $6.3 \%$ insoluble was reported.

International Fertilizer Development Center (IFDC) (Lawendy, et al., 1993) compared several flotation process results, including diphosphonic process, phosphoric acid process, fluosilic acid process, sodium triployphosphric acid process, aluminum sulfate and tartaric acid process, etc. It was found that the phosphoric acid depression process gave the best results. The grades of the concentrate were $32.2-36.6 \% \mathrm{P}_{2} \mathrm{O}_{5}, 1.0 \% \mathrm{MgO}$ at $70-75 \%$ overall $\mathrm{P}_{2} \mathrm{O}_{5}$ recovery from run-of-mine rocks containing $16.7-25 \% \mathrm{P}_{2} \mathrm{O}_{5}$ and $4.0-11.6 \%$ $\mathrm{MgO}$.

One of the most frequently mentioned Tennessee Valley Authority (TVA) processes is the diphosphonic acid depressing method (1985; Lehr and Hsieh, 1981). At reagent dosages of $2 \mathrm{~kg}$ of fatty acid, $0.4 \mathrm{~kg}$ of fuel oil, and $0.5 \mathrm{~kg}$ depressant per ton of feed, a concentrate with $0.7 \% \mathrm{MgO}$ was achieved. 
Studies conducted by International Mineral \& Chemical-Agrico Company (IMCA) (Gruber, Raulerson, and Farias, 1987) indicated that complete depression of phosphate could be achieved by adjusting pulp $\mathrm{pH}$ by sulfuric acid to 5.5 in seawater and 3.0 in fresh water.

Calcite in a Moroccan phosphate ore was successfully depressed using a 2:1 mixture (by weight) of aluminum sulfate and tartaric acid (Smani, Cases, and Blazy, 1975; Houot and Polgaire, 1980). A concentrate with $32.1 \% \mathrm{P}_{2} \mathrm{O}_{5}$ and $0.43 \% \mathrm{MgO}$ was obtained from a feed containing $23.24 \% \mathrm{P}_{2} \mathrm{O}_{5}$ and $3.29 \% \mathrm{MgO}$. Reagent dosages were $1300-1500 \mathrm{~g}$ oleic acid, 200-250 g aluminum sulfate, 400-500 g Na-K-tartarate, 650-750 g alcohol, and 500-600 g soda per ton of feed.

Rao et al. $(1985,1979)$ conducted an extensive study on an Indian carbonaceous phosphate ore. Comparison tests on hydrofluosilicic acid, starch and dipotassium hydrogen phosphate showed that $\mathrm{K}_{2} \mathrm{HPO}_{4}$ was superior to the others in depressing phosphate in the test sample. One of the important findings of this study was that $\mathrm{K}_{3} \mathrm{PO}_{4}$ depressed apatite flotation completely at $\mathrm{pH} 5$ to 8 , while calcite flotation was depressed only under alkaline conditions. These results suggest that selective floatation is possible by controlling the $\mathrm{pH}$ range of the flotation process, but the final concentrate contained only $24 \% \mathrm{P}_{2} \mathrm{O}_{5}$.

Studies by $\mathrm{Fu}$ and Somasundaran (Fu and Somasundaran, 1986; Xiao and Somasundaran, 1989) showed that calcite was depressed by alizarin red S (ARS) between $\mathrm{pH}$ 8 and 10, while apatite depression occurred at $\mathrm{pH}$ below 6 . Therefore, ARS could be used either as a carbonate depressant or apatite depressant by selecting the appropriate $\mathrm{pH}$ range of the flotation pulp. Some fundamental studies on ARS for phosphate beneficiation have also been conducted by Wu and Forsling (1993). 
Sulfuric acid was used as a depressant for phosphate and $\mathrm{pH}$ modifier, and a fatty acid type collector was used to dolomite at a $\mathrm{pH} 5.5$ for processing a Chinese high dolomite phosphate ore. A phosphate concentrate containing $36 \% \mathrm{P}_{2} \mathrm{O}_{5}$ and $0.95 \% \mathrm{MgO}$ was obtained from a feed of $30.5 \% \mathrm{P}_{2} \mathrm{O}_{5}$ and $4.5 \% \mathrm{MgO}$ at a $\mathrm{P}_{2} \mathrm{O}_{5}$ recovery more than $95 \%$ ( $\mathrm{Lu}$ and Sun, 1998).

Recently, a fine particle flotation process was developed to process Florida dolomitic phosphate pebble with a mixture of phosphoric acid as phosphate depressant and a fatty acid soap as dolomite collector (Gu and Gao, 1998; Gao, Zheng and Gu, 2001). A phosphate concentrate analyzing $31 \% \mathrm{P}_{2} \mathrm{O}_{5}$ and $0.8 \% \mathrm{MgO}$ could be produced at a $\mathrm{P}_{2} \mathrm{O}_{5}$ recovery more than $80 \%$ from a sample of $25.5 \% \mathrm{P}_{2} \mathrm{O}_{5}$ and $2.2 \% \mathrm{MgO}$. It is also reported that the sample was ground to minus 100 mesh for liberation and all the ground material was subjected to flotation without desliming.

A mixture of orthophosphoric acid and sulfuric acid was used to depress phosphate in processing an Indian low-grade calcareous phosphate rock by Prasad (2000). A concentrate containing $29.5 \% \mathrm{P}_{2} \mathrm{O}_{5}$ with $\mathrm{CaO} / \mathrm{P}_{2} \mathrm{O}_{5}$ ratio of 1.62 could be obtained from the feed of $13 \%$ $\mathrm{P}_{2} \mathrm{O}_{5}$ and $\mathrm{CaO} / \mathrm{P}_{2} \mathrm{O}_{5}$ ratio of 2.53 . The $\mathrm{P}_{2} \mathrm{O}_{5}$ recovery was $60 \%$.

\subsection{Depression of Carbonate}

Sodium silicate is widely used as a carbonate depressant in beneficiating some industrial minerals. The depressive effect of sodium silicate on carbonatic gangues in phosphate rock is also investigated (Fuerstenau, 1968; Rao, 1988; Ananthapadmanabhan and 
Somasundaran). Some encouraging results were obtained in both batch and continuous pilot tests conducted by USBM (Davis, Llewellyn, and Smith, 1984).

Rao et al. (1989) studied the effects of major flotation parameters on phosphate grade and recovery using sodium silicate as a calcite depressant. Maximum flotation of apatite

occurred at $\mathrm{pH} 8$, and phosphate recovery decreased at high $\mathrm{pH}$. Sodium silicate at a concentration below $0.0013 \mathrm{M}$ had no depressive effect on calcite. However, at $\mathrm{pH}$ values above 10 calcite depression was observed even in dilute silicate solution. A concentrate with $25.6 \% \mathrm{P}_{2} \mathrm{O}_{5}$ was achieved at $80 \% \mathrm{P}_{2} \mathrm{O}_{5}$ recovery.

In an effort to determine if apatite could be concentrated by flotation from high dolomitic phosphate ores using conventional fatty acid-fuel oil flotation, Llewellyn et al. (1982) found that sodium silicate depression on dolomite was not significant enough to obtain a concentrate with less than $1 \% \mathrm{MgO}$ even with three stages of cleaning and the addition of $1.36 \mathrm{~kg} /$ ton of sodium silicate. Numerous tests conducted by IMC in the past 20 years and a study by FIPR (Snow 1994) also indicated that sodium silicate is virtually powerless in depressing dolomite in the Florida dolomitic pebbles.

\subsection{Acid Leaching}

Carbonates in phosphate rock can be easily leached by any strong acid. Unfortunately, strong acids also attack the apatite while leaching carbonates. This is one of the major obstacles to utilizing acid leaching processes for removing carbonates, especially dolomite from phosphate ores. To avoid attacking phosphate, weak acids have been studied as leaching agents. However, these organic acids are usually too expensive to justify their 
utilization. Nonetheless, because of its low capital cost and effective removal of carbonates, acid leaching has been studied continually.

In the early seventies, USBM investigated several leaching agents for the removal of magnesium impurities from phosphate rock concentrates (Rule, et al., 1970). The $\mathrm{MgO}$ level was reduced to less than $0.1 \%$ with dilute sulfuric acid from a concentrate roasted at $500^{\circ} \mathrm{C}$. However, phosphate loss was substantial. Removal of $\mathrm{MgO}$ by ammonium sulfate leaching was achieved only from concentrates roasted at $900^{\circ} \mathrm{C}$. Phosphate loss was minimal when concentrates were leached with $\mathrm{SO}_{2}$ gas; and reduction of $\mathrm{MgO}$ level to $0.3 \%$ was achieved with uncalcined phosphate rock.

Leaching of magnesium from phosphate using sulfuric acid has been actively pursued by the Russian investigators (Kromf, et al. 1979; Belyakov, et al., 1981). In one study, the quality of wet-process phosphoric acid was improved by sulfuric acid pretreatment. A concentrate containing $37.2 \% \mathrm{P}_{2} \mathrm{O}_{5}, 50.7 \% \mathrm{CaO}$ and $0.76 \% \mathrm{MgO}$ was produced from a raw apatite assaying $37.8 \% \mathrm{P}_{2} \mathrm{O}_{5}, 53 \% \mathrm{CaO}$ and $2.6 \% \mathrm{MgO}$ (Valoven, 1979). Some intriguing concepts evolved from the study of the sulfuric acid leaching process (Laird and $\mathrm{Ng}, 1992$ ) are: a) expelling the carbon dioxide produced by leaching, b) accurate $\mathrm{pH}$ control by computer, and c) converting soluble magnesium into magnesium nitrate.

Weak organic acids such as acetic acid, citric acid and formic acid can also be used for leaching carbonates. Acetic acid seems to offer some advantages. A pilot study by AbuElshah et al. (1991) found that a $6.7 \%$ acetic acid solution could effectively remove more than $80 \% \mathrm{MgO}$ and obtain a concentrate of over $32 \% \mathrm{P}_{2} \mathrm{O}_{5}$ from a Jordan phosphate ore in a water to solid ratio of 4:1 slurry. Acetic acid was recovered from the acetate solution by the reaction of calcium acetate with sulfuric acid. 


\subsection{Calcination}

Calcination is a rather mature and technically sound pyro-metallurgical unit operation, and it is the only industrially used technology for complete removal of carbonates from phosphate rock, particularly rock that is high in calcareous gangues. Africa and the Western U.S. have been using calcination for many years.

Recently calcination was studied and recommended in Saudi Arabia where the water supply is limited and energy is inexpensive. A Saudi phosphate ore containing 40-50\% carbonate and $16-25 \% \mathrm{P}_{2} \mathrm{O}_{5}$ was treated by calcination at $850^{\circ} \mathrm{C}$ for about an hour, followed by quenching with $5 \% \mathrm{NH}_{4} \mathrm{NO}_{3}, 5 \% \mathrm{NH}_{4} \mathrm{Cl}$, or water. Under the best test conditions, a concentrate containing 38\% $\mathrm{P}_{2} \mathrm{O}_{5}$ was produced (Al-Fariss, 1993).

Two low grade Indian carbonaceous ores were successfully upgraded using a continuous-flow calcination process (Good, 1976). Phosphate recoveries ranged from 63 to $84.6 \%$ with concentrate grades of 31.3 to $38.5 \%$. The roasting temperature was $900^{\circ} \mathrm{C}$.

\subsection{Physical Separation Methods}

Although spirals, shaking tables and some other physical techniques have been used for eliminating part of carbonate gangue from phosphates, none of them alone could achieve an acceptable concentrate from high dolomitic phosphate ores (Baumann and Snow, 1980). IMCA leads the phosphate industry in commercializing physical technology for separating dolomite from apatite (Lawver and Snow, 1982; Wiegel and Hwang 1984). Using the heavy 
media separation technique, IMCA is able to obtain a concentrate with a $\mathrm{MgO}$ content around $1.2 \%$ from feeds with average value of $3 \% \mathrm{MgO}$. This relatively high dolomite concentrate is then blended with high $\mathrm{P}_{2} \mathrm{O}_{5}$ concentrates to obtain a blended product of less than $1 \% \mathrm{MgO}$.

Scrubbing prior to either dolomite or phosphate flotation has been tested on two of the Florida dolomitic phosphate pebble samples with some degree of success (Davis, Llewellyn, and Smith, 1984). The friable dolomite crystals were eliminated by scrubbing the $-300+106 \mu \mathrm{m}(-35+150 \mathrm{mesh})$ size fraction flotation feed. Discarding the primary, secondary, and scrubbing slimes removed $92 \%$ percent of the total $\mathrm{MgO}$ content from one of the samples. While investigating beneficiation methods for recovering phosphate minerals from two southern Florida deposits with high magnesium content, Llewellyn et al. (1982) was able to remove $92.7 \%$ of the total $\mathrm{MgO}$ content from one sample taken from Manatee county, and $85.4 \%$ from another sample from Hardee county by simply discarding minus $100 \mu \mathrm{m}$ fines after intensive attrition.

\subsection{Column Flotation}

The first all column flotation plant was installed in 1980's for processing western aluminum-bearing phosphate ore at Pocatello, ID (Finch and Dobby, 1991; Polinsky, Bierman and Perkins, 1989). The test results indicated that $50 \%$ of $\mathrm{Al}_{2} \mathrm{O}_{3}$ was rejected and $70 \%$ of $\mathrm{P}_{2} \mathrm{O}_{5}$ was recovered from the phosphate ore containing 2.3-2.7\% $\mathrm{Al}_{2} \mathrm{O}_{3}$ and $27.5 \%$ $\mathrm{P}_{2} \mathrm{O}_{5}$, applying fluosilic acid as depressant and fatty acid as collector. 
Some investigators have also conducted researches on applying flotation column for beneficiating siliceous phosphate ores. Hutwelker (1993) used a $9.5 \mathrm{~cm}$ diameter by $2.26 \mathrm{~m}$ tall column to process $-20+200$ mesh North Carolina phosphate ore at $45 \%$ solids and at throughputs of 19.1 and $31.7 \mathrm{t} / \mathrm{hr} / \mathrm{m}^{2}$. A phosphate concentrate containing 26 to $29 \% \mathrm{P}_{2} \mathrm{O}_{5}$ was produced at the $\mathrm{P}_{2} \mathrm{O}_{5}$ recovery of $95 \%$ from North Carolina phosphate feed.

El-Shall et al. (1996) applied a $14.6 \mathrm{~cm}$ diameter and $1.83 \mathrm{~m}$ height laboratory-size column for flotation of Florida siliceous phosphate ores of different size ranges. It was reported that it was capable of obtaining a $98 \%$ recovery with up to $31 \% \mathrm{P}_{2} \mathrm{O}_{5}$ concentrate from a feed of $19.7 \% \mathrm{P}_{2} \mathrm{O}_{5}$ and $39.8 \%$ acid insoluble.

Mahlangu et al. (1998) tried to recover phosphate from a 90-95\% minus $45 \mu \mathrm{m}$ phosphate slimes by applying a $5.08 \mathrm{~cm}$ ID and $5.5 \mathrm{~m}$ height flotation column. The test results indicated that a concentrate containing 22.87-31.21\% $\mathrm{P}_{2} \mathrm{O}_{5}$ could be achieved at the $\mathrm{P}_{2} \mathrm{O}_{5}$ recovery of $52.6-74.5 \%$ from an igneous phosphate ore containing $4.3 \% \mathrm{P}_{2} \mathrm{O}_{5}, 11.8 \%$ $\mathrm{MgO}$ and $9.0 \% \mathrm{Al}_{2} \mathrm{O}_{3}$.

In Florida phosphate production, one third phosphate is bound to the phosphate slimes which is currently discarded into huge tailings ponds in central Florida. The phosphatic slime contains very high dolomite which is the most problematic ingredient in wet phosphate acid process. Ityokumbul (1998) attempted to recover the phosphate value from this fine phosphatic slime using a contact flotation cell. Although great efforts were made on this subject, the final results were not encouraging. No satisfactorily selective separation was obtained.

Abdel-Khalek et al. (2000) studied the possibility of recovering fine phosphate $(<45 \mu \mathrm{m})$ from the slimes with column flotation using oleic acid as a phosphate collector and 
sodium silicate as depressant. It is reported that a phosphate concentrate containing $25.3 \%$ $\mathrm{P}_{2} \mathrm{O}_{5}$ and $14.64 \%$ insoluble could be produced at the $\mathrm{P}_{2} \mathrm{O}_{5}$ recovery of $51.52 \%$ from the feed of $18.26 \% \mathrm{P}_{2} \mathrm{O}_{5}$ and $24.03 \%$ insoluble.

El-Shall et al. (2000) investigated the effects of frother type, collector and $\mathrm{pH}$ on the efficiency of column flotation of Florida phosphate and found that the interaction between frothers and collector and consequently the flotation efficiency were independent on frother type.

\subsection{Other Development}

In the IMCA cationic process (Lawver and Snow 1980), a silica-free concentrate (either from a conventional "double float" process or one from a simple standard silica flotation step) is conditioned with a cationic collector at low $\mathrm{pH}$, and then apatite is floated by rougher, cleaner and recleaner phosphate flotations.

University of Alabama (UA) has developed a process called non-conditioning flotation (Hanna and Anazia, 1990), which is based on the fact that fatty acids adsorb more rapidly on carbonate surfaces than on those of phosphate. Thus, in a slightly acid circuit, carbonates could be floated immediately upon addition of the collector and frother. After collection of the carbonate froth the pulp was conditioned briefly and then floated without further addition of collector.

A two-stage conditioning process has been developed by University of Florida (UF) (Moudgil, et al., 1986). In this new process the mineral is conditioned first at an alkaline $\mathrm{pH}$ with a conventional fatty acid collector, then reconditioned in a second stage at an acidic $\mathrm{pH}$ 
with the same collector solution before flotation. Separation of dolomite from apatite is achieved without adding any depressant or other modifying agent. Selective flotation of dolomite by reconditioning at $\mathrm{pH} 4$ is attributed to the combined effect of higher oleate adsorption on dolomite and hydrolysis of adsorbed oleate molecules to oleic acid at lower $\mathrm{pH}$ values.

Houot and Polgaire (1980) developed a double reverse flotation scheme for high carbonate phosphate ores. In this process, an reverse cationic flotation is first conducted to eliminate silica. The sink of silica flotation is then subjected to an anionic flotation to reject the carbonate. The study found that particle size had a significant effect on silica flotation and concluded that reverse flotation was a competitive solution for the beneficiation of sized ores of less than about 35-32 mesh.

Abdel-Khalek (2001) found that dodecyl-N-carboxyethyl-N-hydroxy-ethylimidazoline could be used as a collector for the separation of dolomite from phosphate. A phosphate concentrate containing $0.5 \% \mathrm{MgO}$ and $32.2 \% \mathrm{P}_{2} \mathrm{O}_{5}$ was obtained from a mixture of natural phosphate and dolomite minerals with $10.2 \% \mathrm{MgO}$ and $24.1 \% \mathrm{P}_{2} \mathrm{O}_{5}$. 


\section{CHAPTER 3 EXPERIMENTS}

\subsection{Materials}

\subsubsection{Source of Dolomitic Phosphate Pebble Sample}

The dolomitic phosphate pebble (DDP) sample with high dolomite content for this study was collected from the pebble stockpile of IMCA, Lakeland, Pork County, Florida, through Florida Institute of Phosphate Research (FIPR). For phosphate production in Florida, the phosphate matrix is mined by high capacity dragline. The matrix mined is made into slurry using high pressure water jet and then pumped to the phosphate beneficiation plant for washing operation using spiral classifier. After washing, the matrix is split by screens and cyclones into three streams, usually $+1 \mathrm{~mm},-1+0.1 \mathrm{~mm}$ and $-0.1 \mathrm{~mm}$ size fractions. The minus $0.1 \mathrm{~mm}$ (minus 150 Tyler mesh) fines as phosphatic slimes, which is discarded into tailings ponds due to its high impurities and low $\mathrm{P}_{2} \mathrm{O}_{5}$ content. The size fraction of $-1+0.1$ $\mathrm{mm}$ is fed to conventional two stage "Crago" flotation process to recover phosphate concentrate by rejecting silica. The plus $1 \mathrm{~mm}$ coarse size fraction is known as phosphate pebble. This fraction is usually mixed with flotation concentrate to form a composite product for downstream production, if its $\mathrm{MgO}$ content is lower than a certain limit, such as $1.0 \sim 1.5 \%$. If the $\mathrm{MgO}$ content is higher than certain amount, it is considered as dolomitic phosphate pebble (DPP) and will be discarded as waste. In Florida, there is a three-one-third principle, namely one third of the phosphate mineral is bound with slimes, one third is 
recovered with the "Crago" flotation process and another one third is contained in phosphate pebble.

\subsubsection{Characterization of Dolomitic Phosphate Pebble Sample}

\subsubsection{Size Distribution and Chemical Analysis}

Chemical analysis of the DPP sample is given in Table 3-1. It can be seen that the DPP sample contains $26.7 \% \mathrm{P}_{2} \mathrm{O}_{5}, 2.1 \% \mathrm{MgO}$ and $8.8 \% \mathrm{SiO}_{2}$. The beneficiation process should be capable of rejecting both dolomite and silica for obtaining an acceptable phosphate concentrate containing over $30 \% \mathrm{P}_{2} \mathrm{O}_{5}$ and less than $1 \% \mathrm{MgO}$ at the $\mathrm{P}_{2} \mathrm{O}_{5}$ recovery as high as possible.

Table 3-1 Chemical Analysis of Dolomitic Phosphate Pebble Sample

\begin{tabular}{|c|c|c|c|c|c|c|}
\hline Component & $\mathrm{P}_{2} \mathrm{O}_{5}$ & $\mathrm{MgO}$ & $\mathrm{SiO}_{2}$ & $\mathrm{CaO}$ & $\mathrm{Fe}_{2} \mathrm{O}_{3}$ & $\mathrm{Al}_{2} \mathrm{O}_{3}$ \\
\hline$\%$ & 26.70 & 2.10 & 8.81 & 42.11 & 1.71 & 0.88 \\
\hline
\end{tabular}

The size distribution of the DDP sample and chemical analysis of each size fraction are presented in Table 3-2. The analysis results show that plus $4 \mathrm{~mm}$ coarse fraction contains $4.36 \% \mathrm{MgO}$ content, and minus $0.1 \mathrm{~mm}$ fine fraction contains greater than $8 \% \mathrm{MgO}$ content. These size fractions have much higher MgO compared with other size fractions. Particularly the $\mathrm{P}_{2} \mathrm{O}_{5}$ grade in minus $0.1 \mathrm{~mm}$ size fraction is much lower than in plus $0.1 \mathrm{~mm}$ size fraction. This is mainly because the carbonate minerals such as dolomite and limestone are 
Table 3-2 Size Distribution and Chemical Assay of Each Size Fraction for Dolomitic Phosphate Pebble Sample

\begin{tabular}{|c|c|c|c|c|c|c|c|c|c|c|c|}
\hline \multirow{2}{*}{$\begin{array}{l}\text { Size } \\
(\mathrm{mm})\end{array}$} & \multirow{2}{*}{$\begin{array}{l}\text { Wt. } \\
(\%)\end{array}$} & \multicolumn{5}{|c|}{ Grade, $\%$} & \multicolumn{5}{|c|}{ Recovery, \% } \\
\hline & & $\mathrm{P}_{2} \mathrm{O}_{5}$ & $\mathrm{MgO}$ & Insol.* & $\mathrm{Al}_{2} \mathrm{O}_{3}$ & $\mathrm{Fe}_{2} \mathrm{O}_{3}$ & $\mathrm{P}_{2} \mathrm{O}_{5}$ & $\mathrm{MgO}$ & Insol.* & $\mathrm{Al}_{2} \mathrm{O}_{3}$ & $\mathrm{Fe}_{2} \mathrm{O}_{3}$ \\
\hline+4 & 14.57 & 22.00 & 4.36 & 7.82 & 0.63 & 1.76 & 12.55 & 26.09 & 11.31 & 10.22 & 16.18 \\
\hline$-4+2$ & 34.77 & 26.92 & 1.90 & 7.94 & 0.80 & 1.72 & 36.66 & 27.13 & 27.40 & 30.97 & 37.73 \\
\hline$-2+1$ & 32.19 & 27.97 & 1.59 & 9.03 & 0.98 & 1.47 & 35.26 & 21.02 & 28.85 & 35.12 & 29.85 \\
\hline$-1+0.5$ & 10.60 & 26.67 & 1.37 & 13.61 & 0.95 & 1.41 & 11.07 & 5.96 & 14.32 & 11.21 & 9.43 \\
\hline$-0.5+0.1$ & 2.97 & 18.76 & 1.24 & 36.35 & 0.81 & 1.06 & 2.18 & 1.51 & 10.72 & 2.68 & 1.99 \\
\hline$-0.1+0.038$ & 3.29 & 13.20 & 8.14 & 17.71 & 1.26 & 1.14 & 1.70 & 11.00 & 5.78 & 4.62 & 2.37 \\
\hline-0.038 & 1.61 & 9.04 & 11.01 & 10.17 & 2.89 & 2.42 & 0.57 & 7.28 & 1.63 & 5.18 & 2.46 \\
\hline Head & 100.0 & 25.53 & 2.43 & 10.08 & 0.90 & 1.59 & 100.0 & 100.0 & 100.0 & 100.0 & 100.0 \\
\hline
\end{tabular}

Note: * Insol. stands for acid insoluble materials. 
more fragile than apatite and easily to be fractured. These data indicates that the minus 0.1 mm size fraction can be deslimed and discarded with very low $\mathrm{P}_{2} \mathrm{O}_{5}$ loss. Although the coarse size fractions also contains high $\mathrm{MgO}$ content, it is not economical to eliminate this fraction because it contains high $\mathrm{P}_{2} \mathrm{O}_{5}$ content. Table 3-3 shows the size distribution and chemical analysis after the rejection of minus $0.1 \mathrm{~mm}$ size fraction. This deslimed DDP sample is then used to prepare the flotation feed for this study.

\subsubsection{Mineral Composition}

X-ray diffraction analysis was carried out to identify the major mineral components of the sample and determine the relevant parameters. The unit cell parameters, refractive index and the specific gravity of phosphate mineral in the sample are shown in Table 3-4, and the mineral compositions of the sample are given in Table 3-5.

Table 3-4 shows that the refractive index of the phosphate mineral of the sample was 1.604 and unit cell parameters, $\mathrm{a}^{\mathrm{o}}$ and $\mathrm{b}^{\circ}$, were 9.33182 and 6.89994 , respectively. These data correspond to a carbonated fluorapatite, usually known as francolite with the chemical formula as $\mathrm{Ca}_{9.6299} \mathrm{Na}_{0.2666} \mathrm{Mg}_{0.1035}\left(\mathrm{PO}_{4}\right)_{5.000}\left(\mathrm{CO}_{3}\right)_{1.00} \mathrm{~F}_{2.40}$. Table 3-5 shows that the sample contained $74 \%$ francolite, $10 \%$ dolomite, $8 \%$ quartz and small amount of other minerals. The mineralogical studies also revealed that the theoretical $\mathrm{P}_{2} \mathrm{O}_{5}$ grade of the pure apatite mineral extracted from this sample was $36.07 \%$ and there was $0.45 \% \mathrm{MgO}$ existing in the lattice of apatite mineral which could not be separated using any of physical procedures without intensive liberation. 
Table 3-3 Size Distribution and Chemical Assay of Each Size Fraction for Dolomitic Phosphate Pebble Sample after Rejecting Minus $0.1 \mathrm{~mm}$ Size Fraction

\begin{tabular}{|c|c|c|c|c|c|c|c|c|c|c|c|}
\hline \multirow{2}{*}{$\begin{array}{l}\text { Size } \\
(\mathrm{mm})\end{array}$} & \multirow{2}{*}{$\begin{array}{l}\text { Wt. } \\
(\%)\end{array}$} & \multicolumn{5}{|c|}{ Grade, \% } & \multicolumn{5}{|c|}{ Recovery, \% } \\
\hline & & $\mathrm{P}_{2} \mathrm{O}_{5}$ & $\mathrm{MgO}$ & Insol.* & $\mathrm{Al}_{2} \mathrm{O}_{3}$ & $\mathrm{Fe}_{2} \mathrm{O}_{3}$ & $\mathrm{P}_{2} \mathrm{O}_{5}$ & $\mathrm{MgO}$ & Insol.* & $\mathrm{Al}_{2} \mathrm{O}_{3}$ & $\mathrm{Fe}_{2} \mathrm{O}_{3}$ \\
\hline+4 & 15.32 & 22.00 & 4.36 & 7.82 & 0.63 & 1.76 & 12.85 & 31.93 & 12.21 & 11.33 & 17.00 \\
\hline$-4+2$ & 36.56 & 26.92 & 1.90 & 7.94 & 0.80 & 1.72 & 37.51 & 33.20 & 29.59 & 34.33 & 39.64 \\
\hline$-2+1$ & 33.85 & 27.97 & 1.59 & 9.03 & 0.98 & 1.47 & 36.08 & 25.72 & 31.16 & 38.94 & 31.37 \\
\hline$-1+0.5$ & 11.15 & 26.67 & 1.37 & 13.61 & 0.95 & 1.41 & 11.33 & 7.30 & 15.46 & 12.43 & 9.91 \\
\hline$-0.5+0.1$ & 3.12 & 18.76 & 1.24 & 36.35 & 0.81 & 1.06 & 2.23 & 1.85 & 11.57 & 2.97 & 2.09 \\
\hline Head & 100.0 & 26.24 & 2.09 & 9.81 & 0.85 & 1.59 & 100.0 & 100.0 & 100.0 & 100.0 & 100.0 \\
\hline
\end{tabular}

Note: * Insol. stands for acid insoluble materials 
Table 3-4 Unit Cell Parameters, Refractive Index and Specific Gravity of Phosphate Mineral in Dolomitic Phosphate Pebble Sample

\begin{tabular}{|c|c|c|c|}
\hline \multicolumn{2}{|c|}{ Unit Cell Parameters } & \multirow{2}{*}{$\begin{array}{c}\text { Refractive } \\
\text { Index }\end{array}$} & $\begin{array}{c}\text { Specific Gravity } \\
\left(\text { grams } / \mathrm{cm}^{3}\right)\end{array}$ \\
\cline { 1 - 2 } $\mathrm{a}^{0}$ & $\mathrm{~b}^{0}$ & 1.604 & 3.11 \\
\hline 9.33182 & 6.89994 & 11 \\
\hline
\end{tabular}

Table 3-5 Mineral Composition of As-Received Dolomitic Phosphate Pebble Sample

\begin{tabular}{|c|c|}
\hline Mineral & Composition, $\%$ \\
\hline Francolite & 74 \\
\hline Dolomite & 10 \\
\hline Quartz & 8 \\
\hline Plagioclase & $1-2$ \\
\hline Microline & $1-2$ \\
\hline Iron oxide & 1 \\
\hline Acorite & Trace \\
\hline Taltalilite & Trace \\
\hline
\end{tabular}




\subsubsection{Mineral Liberation}

A small representative dolomitic phosphate pebble sample was taken and milled to minus $0.5 \mathrm{~mm}$ ( $-32 \mathrm{mesh})$. Microscopic observation was made on different size fractions of the milled sample to determine the percentage of liberated phosphate mineral in each size range. The results of the microscopic observation are presented in Table 3-6. It can be seen that the percentage of liberated phosphate particles increased as the particle size became finer, but there was no significant change after minus $150 \mu \mathrm{m}(-100 \mathrm{mesh})$. In order to achieve high quality phosphate concentrate, the sample should be ground to minus $150 \mu \mathrm{m}$ (100 mesh) for liberating phosphate from gangue minerals.

\subsubsection{Sample Preparation}

As shown in Table 3-3, the minus $150 \mu \mathrm{m}(-100$ mesh) size fraction of the DDP sample contained high $\mathrm{MgO}$ and low $\mathrm{P}_{2} \mathrm{O}_{5}$. For economical reason and in order to minimize the detrimental effects of the primary slimes on flotation process, the as-received sample was wet-sieved to remove $-150 \mu \mathrm{m}(100$ mesh $)$ fines. The minus $150 \mu \mathrm{m}$ fines were discarded and the plus $150 \mu \mathrm{m}$ was used to prepare flotation feed.

The size distribution and chemical analysis in Table 3-3 show that the deslimed phosphate pebble sample contained over $50 \%$ of the particles coarser than $2 \mathrm{~mm}$. The sample was crushed to minus $1.4 \mathrm{~mm}(-12 \mathrm{mesh})$ using a double roll crusher. The size distribution of the crushed sample is presented in Table 3-7. 
Table 3-6 Percentage of Liberated Phosphate Mineral in Different Size Fractions

\begin{tabular}{|c|c|}
\hline $\begin{array}{c}\text { Size } \\
\mu \mathrm{m}(\mathrm{mesh})\end{array}$ & $\begin{array}{c}\text { Liberated Phosphate } \\
(\%)\end{array}$ \\
\hline$-500+300(-32+48)$ & 80 \\
\hline$-300+250(-48+60)$ & 84 \\
\hline$-250+180(-60+80)$ & 86 \\
\hline$-180+150(-80+100)$ & 88 \\
\hline$-150+106(-100+150)$ & 94 \\
\hline$-106+75(-150+200)$ & 94 \\
\hline$-75+45(-200+325)$ & 94 \\
\hline$-45(-320)$ & 94 \\
\hline
\end{tabular}

Table 3-7 Size Distribution of Florida Dolomitic Pebble Sample after Crushed to Minus $1.4 \mathrm{~mm}$ (-12 mesh)

\begin{tabular}{|c|c|c|}
\hline $\begin{array}{c}\text { Size } \\
\mu \mathrm{m}(\mathrm{mesh})\end{array}$ & $\begin{array}{c}\mathrm{Wt} . \\
(\mathrm{g})\end{array}$ & $\begin{array}{c}\mathrm{Wt} . \\
(\%)\end{array}$ \\
\hline$-1400+850(-12+20)$ & 171.4 & 32.85 \\
\hline$-850+500(-20+32)$ & 98.2 & 18.82 \\
\hline$-500+250(-32+60)$ & 136.2 & 26.11 \\
\hline$-250+150(-60+100)$ & 40.3 & 7.72 \\
\hline$-150+75(-100+200)$ & 39.1 & 7.49 \\
\hline$-75+38(-200+400)$ & 14.7 & 2.82 \\
\hline$-38(-400)$ & 21.8 & 4.18 \\
\hline Total & 521.7 & 100.00 \\
\hline
\end{tabular}


A laboratory Sparser rod mill was employed to grind the sample to minus $150 \mu \mathrm{m}(-$ 100 mesh) for satisfactory liberation of phosphate from gangue minerals, particularly liberation of dolomite. The dimension of the rod mill is $200 \mathrm{~mm}$ ID and $250 \mathrm{~mm}$ length. The size, quantity, weight and percentage of the stainless steel rods used as grinding media are presented in Table 3-8.

A series of grinding tests were conducted to determine the grinding time to achieve sufficient liberation using $300 \mathrm{~g}$ and $1000 \mathrm{~g}$ sample size for each batch, respectively. The particle size distribution at different grinding time is presented in Tables 3-9 and 3-10, and plotted in Figures 3-1 and 3-2.

Comparisons of Figures 3-1 and 3-2 shows that the steeper slope in the relationship between the percent passing for a given particle size and grinding time for $300 \mathrm{~g}$ sample size than $1000 \mathrm{~g}$ sample size. The smaller the sample size, the shorter the grinding time to prepare the $100 \%$ passing $150 \mu \mathrm{m}$ size. Six minutes is required to produce $100 \%$ passing $150 \mu \mathrm{m}$ size fraction for $300 \mathrm{~g}$ sample size, while 18 minutes is needed to generate $100 \%$ passing $150 \mu \mathrm{m}$ size fraction for $1000 \mathrm{~g}$ sample size. 
Table 3-8 Stainless Steel Rods as Grinding Media for the Milling Experiment

\begin{tabular}{|c|c|c|c|}
\hline $\begin{array}{c}\text { Rod diameter } \\
(\mathrm{mm})\end{array}$ & $\begin{array}{c}\text { Quantity } \\
\text { (No. of rods) }\end{array}$ & $\begin{array}{c}\text { Weight } \\
(\mathrm{g})\end{array}$ & $\begin{array}{c}\text { Weight } \\
(\%)\end{array}$ \\
\hline 16 & 17 & 8175 & 49.34 \\
\hline 12 & 16 & 5710 & 32.33 \\
\hline 10 & 14 & 3238 & 18.33 \\
\hline Total & 47 & 17663 & 100.00 \\
\hline
\end{tabular}

Table 3-9 Size Distribution at Different Grinding Time for 300 g Dolomitic Phosphate Pebble Sample

\begin{tabular}{|c|c|c|c|}
\hline \multirow{2}{*}{$\begin{array}{c}\text { Grinding Time } \\
(\mathrm{min})\end{array}$} & \multicolumn{3}{|c|}{ Wt.\% Passing } \\
\cline { 2 - 4 } & $\begin{array}{c}-150 \mu \mathrm{m} \\
(-100 \mathrm{mesh})\end{array}$ & $\begin{array}{c}-75 \mu \mathrm{m} \\
(-200 \mathrm{mesh})\end{array}$ & $\begin{array}{c}-38 \mu \mathrm{m} \\
(-400 \mathrm{mesh}))\end{array}$ \\
\hline 2 & 50.26 & 19.13 & 11.47 \\
\hline 4 & 76.22 & 33.54 & 20.26 \\
\hline 6 & 98.98 & 58.23 & 32.63 \\
\hline 8 & - & 75.56 & 45.34 \\
\hline
\end{tabular}

Table 3-10 Size Distribution at Different Grinding Time for 1000 g Dolomitic Phosphate Pebble Sample

\begin{tabular}{|c|c|c|c|}
\hline \multirow{2}{*}{$\begin{array}{c}\text { Grinding Time } \\
(\text { min. })\end{array}$} & \begin{tabular}{c}
$|c|$ \\
Wt.\% Passing \\
\cline { 2 - 4 }$(-100 \mathrm{mesh})$
\end{tabular} & $\begin{array}{c}-75 \mu \mathrm{m} \\
(-200 \mathrm{mesh})\end{array}$ & $\begin{array}{c}-38 \mu \mathrm{m} \\
(-400 \mathrm{mesh}))\end{array}$ \\
\hline 10 & 74.43 & 43.62 & 29.89 \\
\hline 14 & 86.12 & 55.08 & 35.56 \\
\hline 18 & 99.07 & 66.97 & 39.87 \\
\hline 22 & - & 78.34 & 43.24 \\
\hline
\end{tabular}




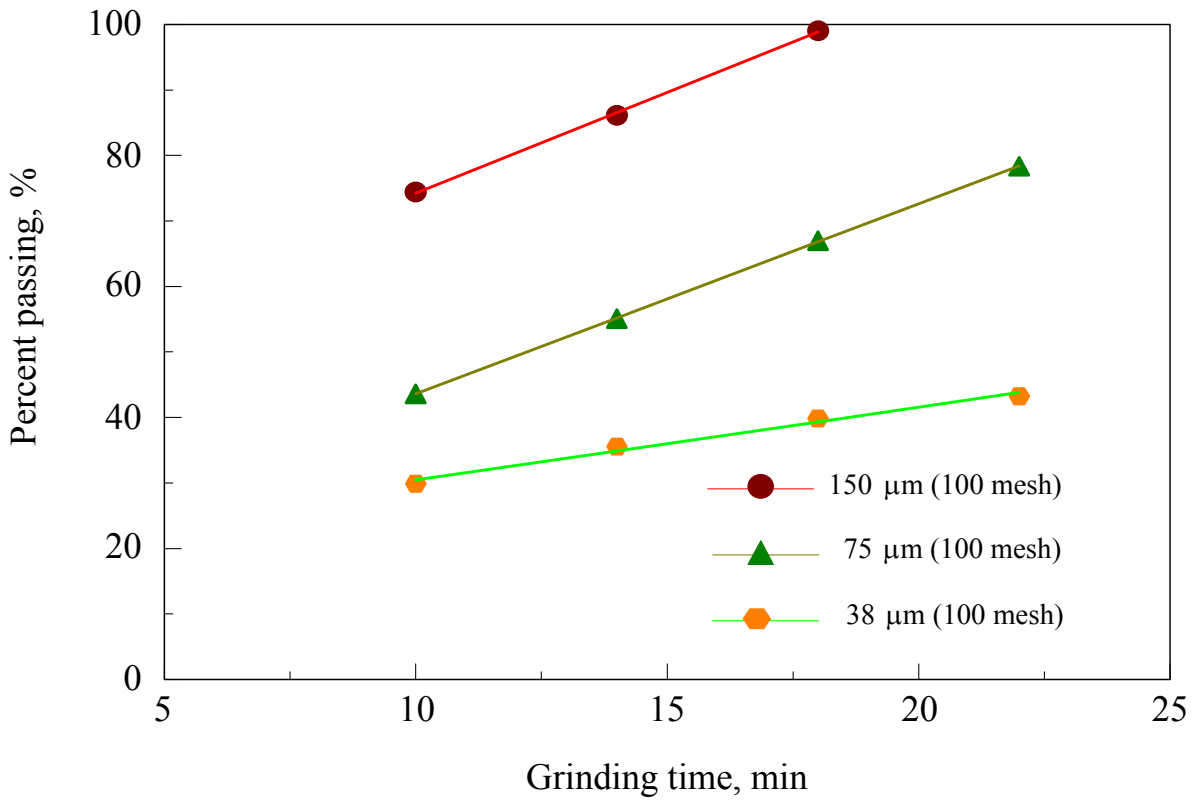

Figure 3-1 Percent Passing as a Function of Grinding Time for $300 \mathrm{~g}$ Sample

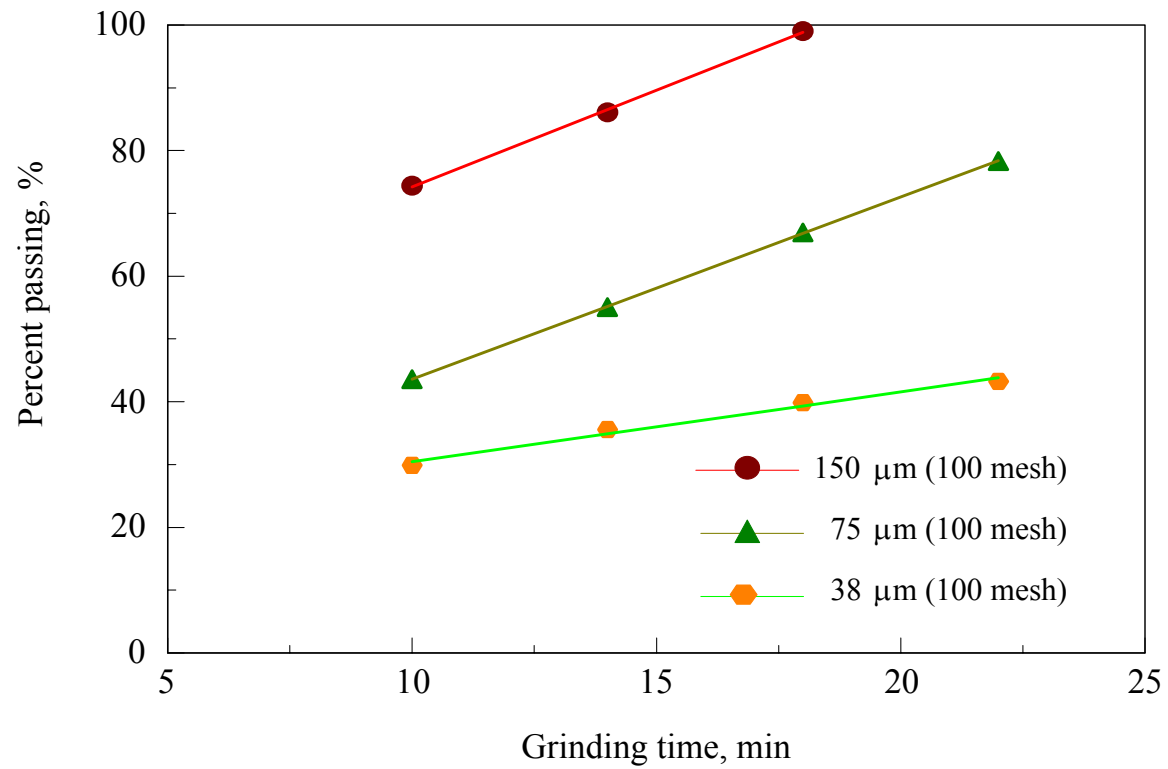

Figure 3-2 Percent Passing as a Function of Grinding Time for $1000 \mathrm{~g}$ Sample 


\subsubsection{Reagents}

In dolomite phosphate flotation experiment, following six reagents are used:

PA-31 collector PA-31, a mixture of C-16 to C-20 fatty acid soap was used as a dolomite collector. PA-31 was derived from saponification of cotton seeds oil residue boiled with sodium hydroxide. This reagent is a yellowish, soap-like solid and water-soluble. $2 \% \mathrm{wt}$ solution is prepared.

FA-12 collector Fatty acid, a mixture of C-16 to C-20 fatty acid was used as a phosphate flotation collector in Florida. It was supplied by ARR-MAZ Products, a Division of Process Chemicals (Winter Haven, FL). The reagent is brownish and insoluble in water. This reagent was causticized with $\mathrm{NaOH}$ which weighs about $14 \%$ of total fatty acid and prepared into $2 \% \mathrm{wt}$. solution for application.

Amine AR-1051 collector Fatty acid amine, AR-1051, provided by ARR-MAZ Products, a Division of Process Chemicals (Winter Haven, FL), was used as quartz collector for separating silica from phosphate. The product is a light brownish liquid and has a good solubility in water. The solution of $2 \% \mathrm{wt}$ concentration was prepared.

Phosphoric acid $\quad \mathrm{H}_{3} \mathrm{PO}_{4}$ is as chemical analysis grade with the purity of $85 \% \mathrm{P}_{2} \mathrm{O}_{5}$ from Fisher Scientific (Pittsburgh, PA). This reagent was used in preparation of a mixture of phosphoric acid and sulfuric acid at the ratio of $2: 1$ by weight and was prepared into $5 \% \mathrm{wt}$ 
solution. The mixture is used as both $\mathrm{pH}$ modifier and depressant of phosphate minerals in dolomitic phosphate flotation.

Sulfuric acid $\quad \mathrm{H}_{2} \mathrm{SO}_{4}$ has the purity of $95-98 \%$ and was supplied by Aldrich Chemical Company (Miwaukee, WI). This reagent was used in preparation of a mixture of phosphoric acid and sulfuric acid at the ratio of $2: 1$ by weight and was diluted to $5 \% \mathrm{wt}$ solution. The mixture was used as both $\mathrm{pH}$ modifier and depressant of phosphate minerals in dolomite flotation.

Kerosene Kerosene was obtained from Fisher Scientific (Pittsburgh, PA). This reagent was used as a collector added in amine flotation for separating silica from phosphate.

\subsection{Apparatus and Procedures}

\subsubsection{Frothability Measurement of Fatty Acids}

The fatty acid reagents used in the dolomitic phosphate flotation are not only collectors, but also a frother. The frothability measurement of the fatty acid reagents were carried out using a froth column meter described elsewhere (Peng and Xia, 2002a; 2002b). The froth column meter was made of $50.8 \mathrm{~mm}$ ID and $1500 \mathrm{~mm}$ height plexiglass tube. The froth was generated by aerating a solution of collector using a fritted glass disc (sparger) at the bottom of the froth column. The fritted glass had $20 \mathrm{~mm}$ diameter and pore size of 40-60 
$\mu \mathrm{m}$. The froth volume as a function of airflow rate for the given concentration of fatty acid and the type of fatty acid were measured.

\subsubsection{Dolomitic Phosphate Flotation Rate}

Dolomitic phosphate flotation was carried out using Denver D-12 model flotation machine and 1.2 liter cell. Three hundred grams dolomitic phosphate sample was wet ground to $100 \%$ passing $150 \mu \mathrm{m}$ for sufficient liberation. The milled slurry was adjusted to $1200 \mathrm{~mL}$ pulp with $25 \%$ solid concentration. A mixture of phosphoric acid and sulfuric acid (2:1 ratio by weight) was added to the pulp to adjust $\mathrm{pH}$ to 5.5 and conditioned for 1 minute. A predetermined amount of collector was added to the pulp and conditioned for another minute. After conditioned with reagents, air was introduced to the flotation cell for 1 minute aeration. For flotation kinetic study, froth was skimmed out into separate pans at time intervals of 15 , $30,60,120,180,300$ and 350 seconds. All the samples including froth and sink were filtered, dried and analyzed.

\subsubsection{Denver Stirrer-Tank Cell Flotation}

Dolomitic phosphate flotation was conducted by changing $\mathrm{pH}$ and collector dosages while maintaining other factors constant, including solid percent of feed, impeller speed and air flow rate. For regular flotation, the froth was collected continuously until the completion of the flotation. The sink remained in the cell was sized at $38 \mu \mathrm{m}$ (400 mesh). The plus 38 $\mu \mathrm{m}$ size fraction was subjected to amine flotation. All the sample were filtered, dried and 
analyzed. The sink product of amine flotation and minus $38 \mu \mathrm{m}$ size fraction were combined to form a composite phosphate concentrate. The procedures of the experiment are described in Figure 3-3.

\subsubsection{Packed Column Flotation}

The dolomitic phosphate flotation tests using PA-31 collector were carried out in a 2 in. ID and $6 \mathrm{ft}$. height packed column. The packing material was made of 0.002 " thickness stainless steel corrugated plates. Each plate had 3/4" pitch running diagonally at $50^{\circ} / 40^{\circ}$ angles. The packed column flotation system is schematically presented in Figure 3-4. The packed flotation column was designed to incorporate a packed bed inside an open column to provide smaller and longer torturous flow passages for sufficient time for particle/bubble contact. The packing structure was to stack up the packed corrugated plates as shown in the Figure 3-4. The packing plates were arranged in blocks positioned in layers at right angles to each other. These stacked corrugated plates obviated the need for the air sparger(s). The compressed air entered into the bottom of the column and the bubbles were generated by snarling between packing plates, and plates and wall. The large bubble deformation occurred in order to pass through the winding narrow paths. No small or fine bubble generation was observed in this study.

The packed flotation column had a feed slurry inlet at the intermediate location, a water inlet at the top for spraying washing water into the column to resin the froth, and an inlet at the bottom of the column for introducing compressed air into the column to generate 


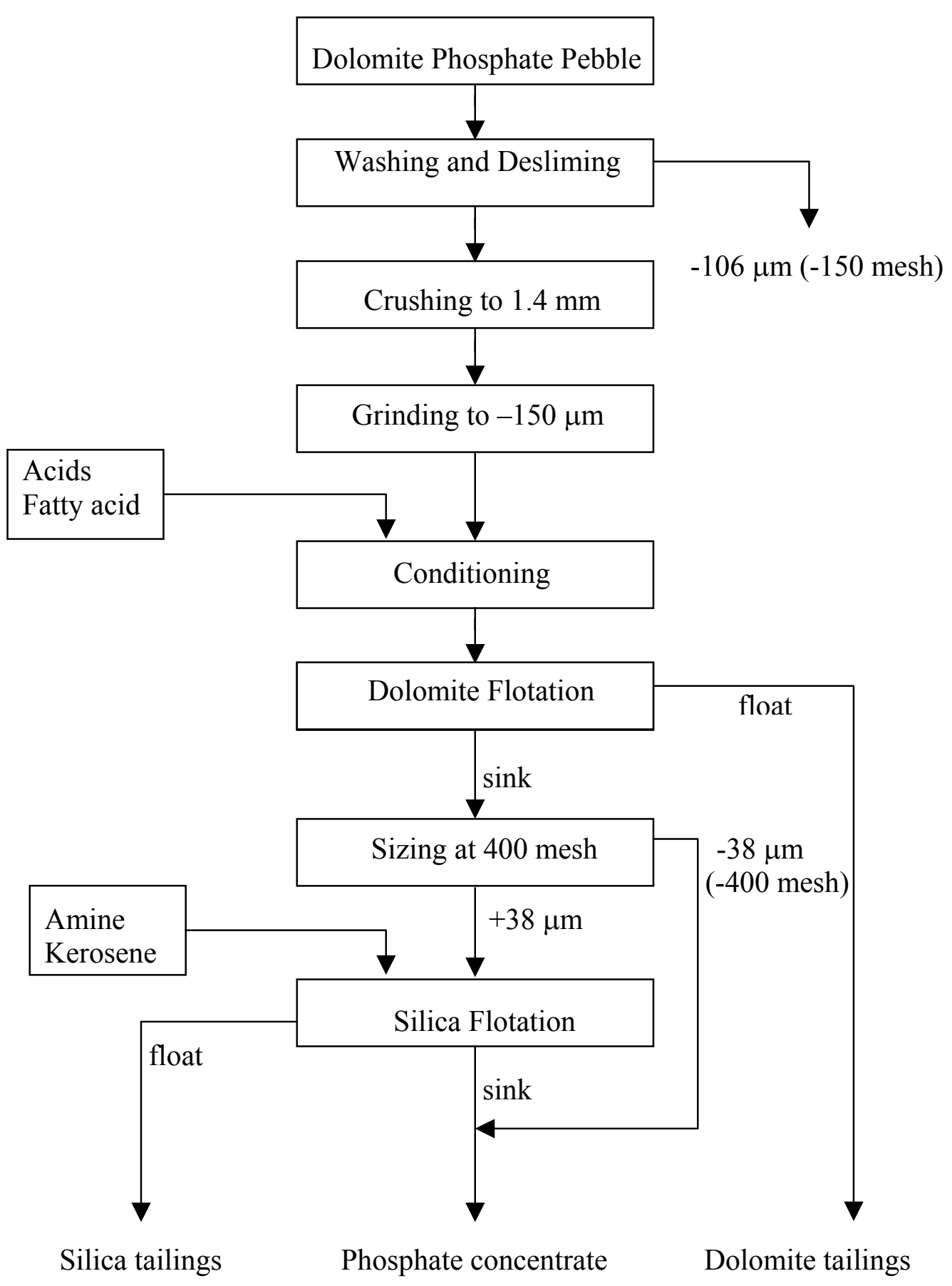

Figure 3-3 Procedures for Processing Florida Dolomitic Phosphate Pebble Sample 


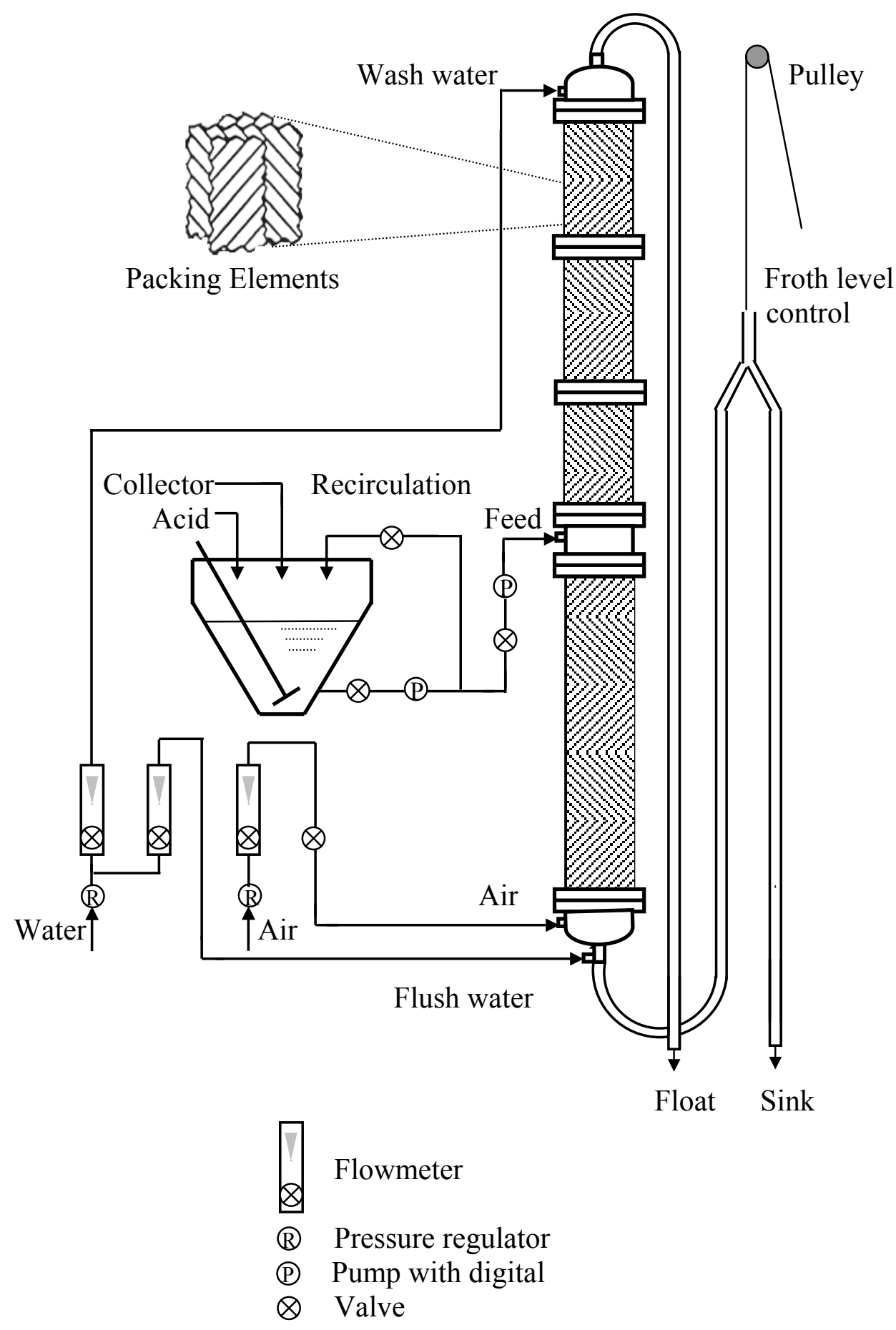

Figure 3-4 Schematic Diagram of 2-in ID Packed Flotation Column System 
bubbles. Washing water came down through a maze of flow passages confined by the packing structure. As air passed upward through the winding flow passages, the bubbles continuously carried the hydrophobic particles into a froth zone in the upper portion of the column, while the hydrophilic particles as sink product was discharged through the outlet at the bottom of the column. Capillary effects between the packing plates supported a controllable froth height. This effect made a deep froth column flotation achievable, when the high number of hydrophobic particles was presented in the pulp. Washing water detached the entrained mineral particles in the froth. The slurry level or the froth interface in the packed column was controlled by adjusting the height of the tubing for the underflow discharge.

Compared with the open column, the packed column has the advantages of (i) no air sparger required because the winding paths between the packing plates make air into bubbles, (ii) column height can be reduced since vertical mixing is avoided by using the structured packings; and (iii) flexibility of the operation by adjusting the interface height between froth and slurry for high number of hydrophobic particles in the feed.

To prepare feed slurry, at least five batches of 1000 grams milled sample were combined and added into the conditioning tank. The slurry was diluted to a desired solid percentage. The slurry was continuously stirred in the tank to maintain the particles in suspension and was circulated through a circulation loop with a pump to achieve the homogeneity of the suspension. The mixture of phosphoric acid and sulfuric acid was added to the circulation loop to modify the $\mathrm{pH}$ of the flotation slurry. The fatty acid soap, PA-31 was also added into the circulation loop after the $\mathrm{pH}$ adjustment. The static mixers and tubing loops were also applied to control the conditioning time to ensure the contact of the mineral 
particles and the reagents. There was no significant effect observed in the flotation results by adding the conditioning loop. Therefore, the flotation tests were conducted without using the static mixer and conditioning loop. The reagentized slurry was fed at about $3 \mathrm{ft}$. height from the bottom of the packed column.

The control parameters considered in the experiment included collector dosage, $\mathrm{pH}$, feed rate, feed solid percent, slurry/froth interface level (froth depth), air flowrate and washing water flowrate. Due to the limited sample quantity and experiment time, fractional two level factorial experimental design was conducted to optimize the operation. The procedure of the experiment design is described in section 3.4.2. During the experiment, a minimum of 20 minutes after each change of operation parameters was needed for the equilibrium of the process. When a steady state of separation was reached for a set of predetermined conditions, both overflow and underflow were collected simultaneously for a

given period, usually one minute. The collected samples were filtered, dried, weighed and analyzed. The weight and analysis data were used for the determination of the yields, grades and recoveries of the products in the process.

Amine flotation tests were conducted using the Denver D-12 model flotation machine and a 1.2 liter stirred-tank flotation cell. The sink discharge was collected from dolomitic phosphate flotation in packed flotation column. The sink sample was sized at $38 \mu \mathrm{m}$ (400 mesh), and plus $38 \mu \mathrm{m}$ was subject to amine flotation to separate silica from phosphate. The silica was collected as froth product, while the phosphate product was remained in the cell.

\subsection{Procedures and Instrument Used for Determination of Phosphate and Magnesium}


Sample preparation: Transfer 0.5 gram sample into a $250 \mathrm{~mL}$ Erlenmeyer flask. Add $20 \mathrm{~mL}$ digestion acid (4 parts $\mathrm{HNO}_{3}$ and 1 part $\mathrm{HCl}$ ). Insert a short stem glass funnel in the neck of the flask. Heat to boiling and simmer at slow boil for 15 minutes. Cool, dilute to approximately $50 \mathrm{~mL}$ with $\mathrm{H}_{2} \mathrm{O}$ and transfer quantitatively into a $250 \mathrm{~mL}$ volumetric flask, dilute to volume, and mix thoroughly. Pipet $5 \mathrm{~mL}$ aliquot into a $100 \mathrm{~mL}$ volumetric flask, add $50 \mathrm{~mL} \mathrm{H}_{2} \mathrm{O}, 20 \mathrm{~mL}$ molybdovanadate reagent, dilute to volume, mix thoroughly and let stand for ten minutes. The standard solutions should be prepared so that the sample or samples fall between two that $10 \% \mathrm{P}_{2} \mathrm{O}_{5}$ apart.

Instruments: $\mathrm{P}_{2} \mathrm{O}_{5}$ was analyzed using an automated ion analyzer, Quik Chem 8000 (Lachat Instruments Hach Company, Milwaukee, WI). MgO analysis was conducted using Optima 3000 DV Inductively Coupled Plasma (Perkin Elmer Instruments company, Norwalk, CT).

\subsection{Separation Efficiency}

The yield of the concentrate, $Y_{c}$ is calculated by the following equation:

$$
Y_{c}=\frac{P_{f}-P_{t}}{P_{c}-P_{t}} \times 100 \%
$$

where $\mathrm{Y}_{\mathrm{c}}$ is yield of concentrate; $\mathrm{P}_{\mathrm{f}}$ is $\mathrm{P}_{2} \mathrm{O}_{5}$ grade in feed; $\mathrm{P}_{\mathrm{c}}$ is $\mathrm{P}_{2} \mathrm{O}_{5}$ grade in concentrate and $\mathrm{P}_{\mathrm{t}}$ is $\mathrm{P}_{2} \mathrm{O}_{5}$ grade in tailings.

The phosphate recovery is defined as

$$
\mathrm{R}_{\mathrm{cp}}=\frac{\mathrm{Y}_{\mathrm{c}} \mathrm{P}_{\mathrm{c}}}{\mathrm{P}_{\mathrm{f}}}(\%)
$$

where $R_{c p}$ is recovery of phosphate in concentrate.

Similarly, the dolomite (as $\mathrm{MgO}$ ) recovery is defined as 


$$
\mathrm{R}_{\mathrm{cd}}=\frac{\mathrm{Y}_{\mathrm{c}} \mathrm{M}_{\mathrm{c}}}{\mathrm{M}_{\mathrm{f}}}(\%)
$$

where $\mathrm{R}_{\mathrm{cd}}$ is the recovery of dolomite in concentrate; $\mathrm{M}_{\mathrm{f}}$ is the $\mathrm{MgO}$ grade in feed and $\mathrm{M}_{\mathrm{c}}$ is $\mathrm{MgO}$ grade in concentrate.

In order to evaluate the performance of the dolomite flotation, selectivity index (SIp) of separating dolomite from phosphate is defined as an evaluation criterion. This selectivity index, SIp is defined as

$$
\mathrm{SIp}=\sqrt{\mathrm{R}_{\mathrm{cp}} \times\left(\mathrm{R}_{\mathrm{cp}}-\mathrm{R}_{\mathrm{cd}}\right) \times \mathrm{P}_{\mathrm{c}} / \mathrm{P}_{\max }}
$$

where $\mathrm{P}_{\max }$ is theoretical $\mathrm{P}_{2} \mathrm{O}_{5}$ grade of the phosphate mineral in the sample. The mineralogical study determined the value of $\mathrm{P}_{\max }=36 \%$ for the dolomitic phosphate sample used in this study.

In Equation (3-4), when more phosphate is recovered and more dolomite is rejected, SIp value becomes larger. Higher $\mathrm{P}_{2} \mathrm{O}_{5}$ grade in concentrate also increases the value of SIp. The value of SIp ranges from 0 to 100 . The value of SIp is zero if there is no selective separation of dolomite from phosphate, i.e., in case of no flotation. If the value of SIp equals to 100 , that means all phosphate mineral is recovered at a pure grade and all impurities are removed. Equation (3-4) will be invalid if the value of $R_{c p}$ is smaller than that of $R_{c d}$. In such a case, the operation is phosphate flotation rather than dolomite flotation. SIp is as a criterion specifically defined for evaluating the performance of separating dolomite from phosphate with dolomite flotation.

\subsection{Experiment Design for Flotation Tests}


For stirred-tank cell flotation, only two parameters, $\mathrm{pH}$ and collector dosages, were varied for the tests in this study. Other parameters including particle size, feed solid percent, aeration rate and impeller speed were kept constant based on previous experience (Gu, Gao and Hwang, 1999). For $\mathrm{pH}$ of pulp and collector dosage, one of them was kept constant while the other one changed at different levels in order to refine the optimal operation conditions.

For packed column flotation, PA-31 collector was used in the experiment, the parameters selected in this study included $\mathrm{pH}$, collector dosage, feed rate, feed solid percent, froth height (interface level), air flow rate and wash water flow rate. Two sets of test runs were performed in screening experiment to identify the factors that have significant effects for the operation levels and to determine the optimum operation conditions. The fractional factorial design is one of the experiment design for screening experiment. In fractional factorial design, the resolution III designs could be constructed for investigating up to $\mathrm{k}=\mathrm{N}$ 1 factors in only $\mathrm{N}$ runs, where $\mathrm{N}$ is a multiple of 4 (Montgamery, 1999; Diamond, 1981). Those experiment designs are frequently used in industrial experimentation. For the first set of test run, the screening experiment similar to the two-level fractional factorial design was made as shown in Table 3-11. This design is quite similar to a $2^{7-4}$ III fractional factorial design. The combination is a one-sixteenth fraction of the $2^{7}$ and a resolution III design with which only main effect can be estimated and all main effects are aliased with two-factor interactions. The estimate of ith effect can be made by $\mathrm{E}_{\mathrm{i}}=2\left(\right.$ Contrast $\left._{\mathrm{i}}\right) / \mathrm{N}=$ Contrasts $_{\mathrm{i}} /(\mathrm{N} / 2)$, where the Contrasts $\mathrm{i}_{\mathrm{i}}$ can be found using the plus and minus signs in the row I, and $\mathrm{N}=2^{7-4}$ is the total number of observations or test runs.

After completion of the first set of test runs and effect analysis, the 7 factors were reduced to 5 factors as shown in Table 3-13. For the second set of test runs with 5 factors, the 
JUMP, V.4 statistics software (SAS Institute Inc., Cary, NC) was used to design the test conditions as shown in Table 3-14.

This is a standard $2^{5-2}$ III fractional factorial design that is a one-eighth fraction of the $2^{5}$. This is also a resolution III design and only main effects can be estimated. The test data was analyzed with the JUMP software. 
Table 3-11 Factors and Levels for the First Set of Test Runs

\begin{tabular}{|l|c|c|}
\hline \multicolumn{1}{|c|}{ Factors } & Low level $(-)$ & High level $(+)$ \\
\hline $\mathrm{A}=$ Collector $(\mathrm{kg} / \mathrm{t})$ & 1 & 1.3 \\
\hline $\mathrm{B}=\mathrm{pH}$ & 4.6 & 5 \\
\hline $\mathrm{C}=$ Feed rate $(\mathrm{mL} / \mathrm{min})$. & 250 & 300 \\
\hline $\mathrm{D}=$ Feed solid $(\%)$ & 20 & 25 \\
\hline $\mathrm{E}=$ Interface $(\mathrm{cm})$ & 50 & 60 \\
\hline $\mathrm{F}=$ Air rate $(\mathrm{L} / \mathrm{min})$. & 4.7 & 5.6 \\
\hline $\mathrm{G}=$ Wash water $(\mathrm{mL} / \mathrm{min})$. & 189 & 252 \\
\hline
\end{tabular}

Table 3-12 Experiment Design for the First Set of Test Runs

\begin{tabular}{|c|c|c|c|c|c|c|c|}
\hline Run & $\mathrm{A}$ & $\mathrm{B}$ & $\mathrm{C}$ & $\mathrm{D}$ & $\mathrm{E}$ & $\mathrm{F}$ & $\mathrm{G}$ \\
\hline 1 & - & - & - & - & - & - & - \\
\hline 2 & - & + & + & + & + & - & - \\
\hline 3 & - & - & + & + & + & + & - \\
\hline 4 & - & - & - & + & + & + & + \\
\hline 5 & + & - & - & - & + & + & + \\
\hline 6 & + & + & - & - & - & + & + \\
\hline 7 & + & + & + & - & - & - & + \\
\hline 8 & + & + & + & + & - & - & - \\
\hline
\end{tabular}


Table 3-13 Factors and Levels for the Second Set of Test Runs

\begin{tabular}{|l|c|c|}
\hline \multicolumn{1}{|c|}{ Factors } & Low level $(-)$ & High level $(+)$ \\
\hline $\mathrm{A}=\mathrm{pH}$ & 5 & 5.5 \\
\hline $\mathrm{B}=$ Collector $(\mathrm{kg} / \mathrm{t})$ & 1.3 & 1.6 \\
\hline $\mathrm{C}=$ Feed rate $(\mathrm{mL} / \mathrm{min})$. & 300 & 350 \\
\hline $\mathrm{D}=$ Interface $(\mathrm{cm})$ & 40 & 50 \\
\hline $\mathrm{E}=$ Air rate $(\mathrm{mL} / \mathrm{min})$ & 3.8 & 4.7 \\
\hline
\end{tabular}

Table 3-14 Experiment Design for the Second Set of Test Runs

\begin{tabular}{|c|c|c|c|c|c|}
\hline Run & A & B & C & D & E \\
\hline 1 & - & - & - & - & + \\
\hline 2 & + & - & - & + & + \\
\hline 3 & - & - & + & + & - \\
\hline 4 & + & + & - & - & - \\
\hline 5 & + & - & + & - & - \\
\hline 6 & - & + & + & - & + \\
\hline 7 & + & + & + & + & + \\
\hline 8 & - & + & - & + & - \\
\hline
\end{tabular}




\section{CHAPTER 4 RESULTS AND DISCUSSIONS}

\subsection{Frothability Evaluation of Collectors}

In froth flotation process, after mineral particles are conditioned with collector, commonly frother is used to control the surface tension of water and thus control the bubble size and the coalescence of bubbles. The hydrophobic particles will attach to the bubbles and rise to slurry surface, and the froth will be collected as the float product. In phosphate industry, fatty acid is widely used for phosphate flotation, but frothers are rarely applied separately. In typical Florida phosphate processing plants, the phosphate mineral particles in size range of 0.1 to $1.0 \mathrm{~mm}$ is conditioned with soda ash as a $\mathrm{pH}$ modifier, then fatty acid is used as a collector and fuel oil as a collector aid to float phosphate. In a typical phosphate processing plant in Guizhou province, China, the dolomitic phosphate ore is wet ground to minus $150 \mu \mathrm{m}$ (100 mesh). The milled slurry is conditioned with acid to $\mathrm{pH} 5-5.5$, a fatty acid type collector PA-31 is added to float dolomite (Gao and Gu, 1998; Lu and Sun, 1998).

It is quite clear that the fatty acid type collector plays a dual function as both collecting and frothing agent in the dolomite phosphate flotation process.

The frothability of two fatty acid type collectors, FA-12 and PA-31, was measured using a froth column meter with the data summarized in Appendix I. Figures 4-1 and 4-2 present the relationship between the froth height and aeration rate for FA-12 and PA-31 at various concentrations, respectively. 


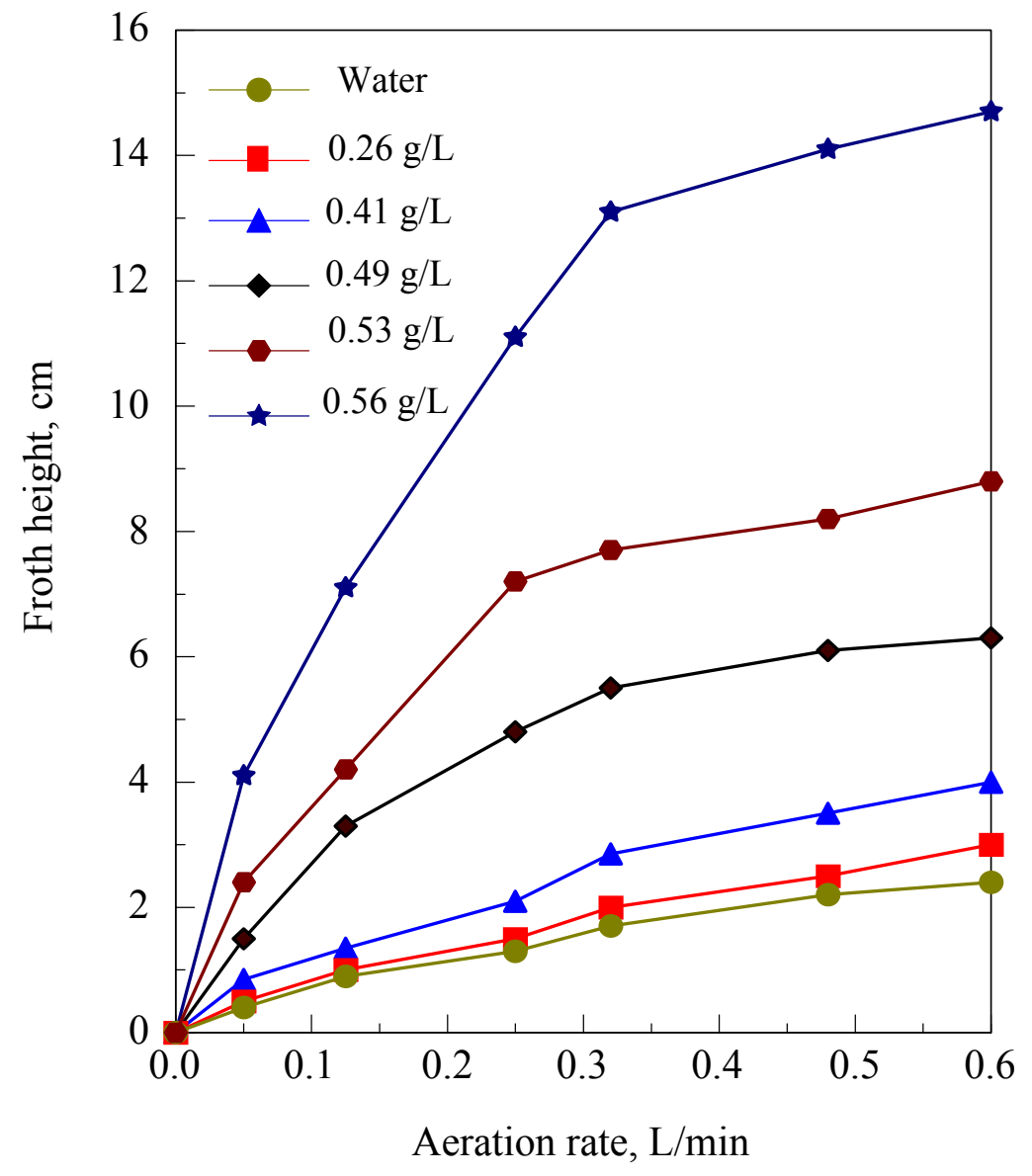

Figure 4-1 Froth Height as a Function of Aeration Rate at Various FA-12 Dosages 


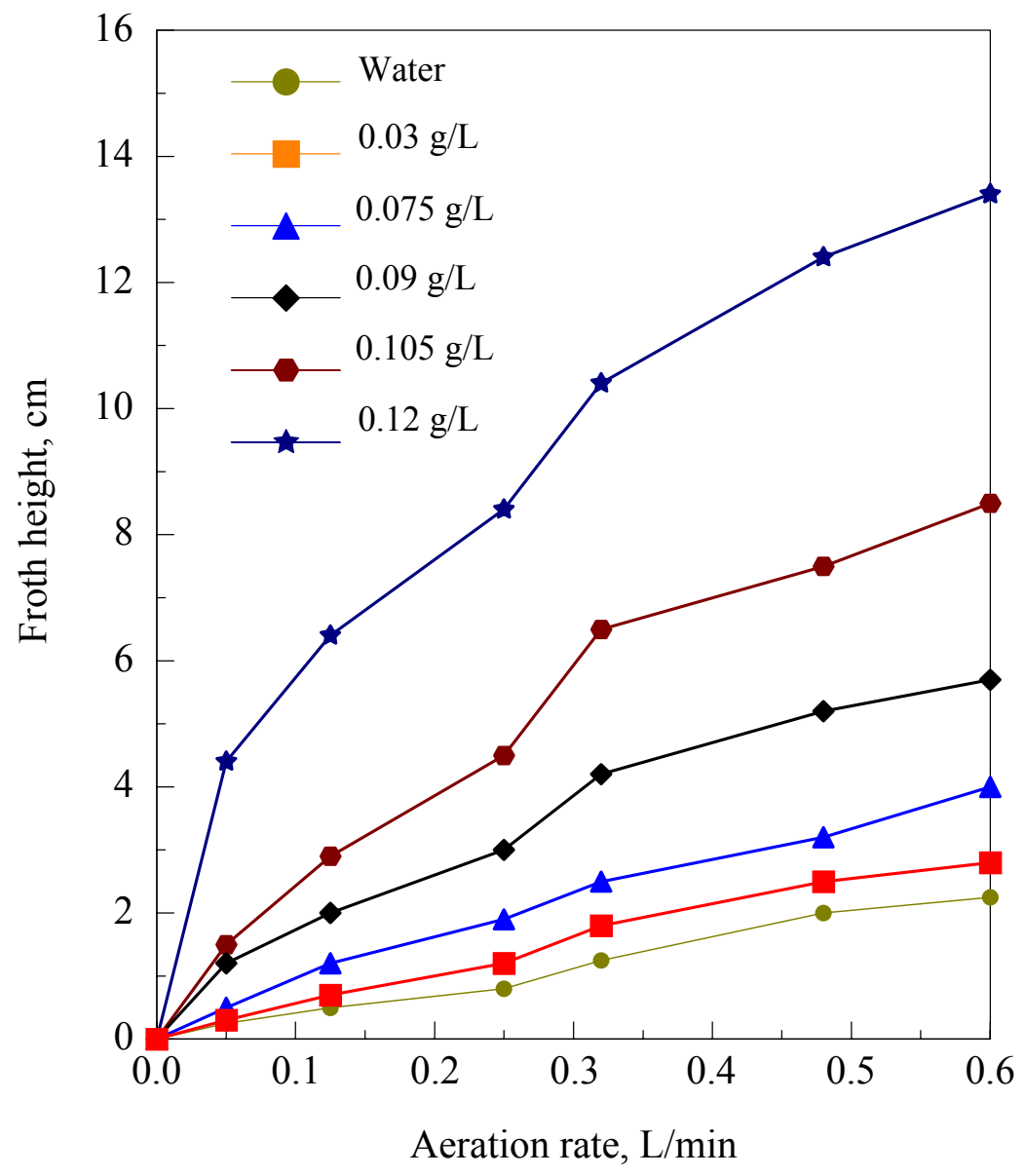

Figure 4-2 Froth Height as a Function of Aeration Rate at Various PA-31 Dosages 
For FA-12, the results show that the froth height increased nearly linearly with the increase of aeration rate at the collector dosages of $0.4 \mathrm{~g} / \mathrm{L}$ or less. When the concentration was increased to $0.56 \mathrm{~g} / \mathrm{L}$, the froth height increased sharply. At FA-12 dosage higher than $0.56 \mathrm{~g} / \mathrm{L}$, this solution formed voluminous and stable froth with small bubbles at the air flow rate as low as $0.05 \mathrm{~L} / \mathrm{min}$. The froth started to build up in the column and flow upward slowly. Then eventually, the froth height exceeded the level of the meter lip and overflowed from the froth column meter. Similar phenomenon was observed for PA-31, but it occurred at much lower concentration. At $0.09 \mathrm{~g} / \mathrm{L}$ concentration, the froth height increased with the increase of air flow rate at a low speed. When the concentration was increased to $0.12 \mathrm{~g} / \mathrm{L}$, the froth height increased sharply as the air flow rate increased. When the reagent dosage was higher than $0.12 \mathrm{~g} / \mathrm{L}$, the froth bed was developed in the column at a low but stable rate and overflow from the lip of froth column meter. Thus, the experiment had to be terminated. At PA-31 dosage of $0.15 \mathrm{~g} / \mathrm{L}$, the froth height exceeds over $50 \mathrm{~cm}$ within 10 minutes even at an aeration rate of $0.125 \mathrm{~L} / \mathrm{min}$. It was found that at low concentrations such as $0.5 \mathrm{~g} / \mathrm{L}$ for FA12 and $0.09 \mathrm{~g} / \mathrm{L}$ for PA-31, the froth was very thin and the froth broke and collapsed very easily. When the concentration reached a given limit of a given collector concentration, such as $0.60 \mathrm{~g} / \mathrm{L}$ for FA-12 and $0.12 \mathrm{~g} / \mathrm{L}$ for PA-31, the froth was very stable, persistent, and no sign of breaking or collapse.

The relationship of froth height and aeration rate at various collector dosages for each type of collectors can be described by the following expressions (Peng and Xia, 2002; Peng and Xia, 2002).

$$
\begin{aligned}
& \mathrm{H}=\mathrm{H}_{0}\left(1-\exp \left(-\mathrm{K}_{\mathrm{f}} \mathrm{Q}\right)\right) \\
& \mathrm{AH}=\mathrm{AH}_{0}\left(1-\exp \left(-\mathrm{K}_{\mathrm{f}} \mathrm{Q}\right)\right)
\end{aligned}
$$


where $\mathrm{H}$ is froth height, $\mathrm{cm}$, at aeration rate $\mathrm{Q}, \mathrm{mL} / \mathrm{min} ; \mathrm{H}_{0}$ is ultimate froth height, $\mathrm{cm} ; \mathrm{K}_{\mathrm{f}}$ is a froth volume constant, $\mathrm{min} / \mathrm{mL}$ and $\mathrm{A}$ is the cross sectional area of the column, $\mathrm{cm}^{2}$. The parameters of Equations (4-1a) and (4-1b) for the fatty acid collectors and distilled water are estimated using PSIPLOT software (Poly Software Int'l, Sandy, UT) and listed in Table 4-1.

From Equations (4-1a) and (4-1b), the instantaneous retention time, Rt, can be derived

$$
\mathrm{Rt}=\frac{\mathrm{d}(\mathrm{AH})}{\mathrm{dQ}}=\mathrm{A} \frac{\mathrm{dH}}{\mathrm{dQ}}=\mathrm{AH}_{0} \mathrm{~K}_{\mathrm{f}} \exp \left(-\mathrm{K}_{\mathrm{f}} \mathrm{Q}\right)
$$

when $\mathrm{Q} \rightarrow 0$, Rt will reach to the maximum value of $\mathrm{AH}_{0} \mathrm{~K}_{0}$, which is the initial retention time, IRT. IRT characterizes the frothability at a given concentration only. The initial retention time as a function of collector dosage is presented in Figure 4-3 for both FA-12 and PA-31. From Figures 4-1 and 4-2, it can be seen that PA-31 has much stronger frothability than FA-12. A concentration of $0.12 \mathrm{~g} / \mathrm{L}$ PA-31 could generate similar amount of froths produced by $0.56 \mathrm{~g} / \mathrm{L}$ FA- 12 .

The relationship between IRT and reagent dosage can be expressed by

$$
\text { IRT }-\operatorname{IRT}_{\text {water }}=\operatorname{IRT}_{\infty}\left(1-\exp \left(-\mathrm{K}_{\mathrm{d}} \mathrm{C}\right)\right)
$$

where IRT $T_{\infty}$ is the limiting value of IRT for $\mathrm{C}->0$; $\mathrm{C}$ is the concentration of collector and $\mathrm{K}_{\mathrm{d}}$ is a concentration constant.

For the reagent that has the dual functions as frother and collector such as fatty acid in this study, the relationship between IRT and reagent concentration shows no sign of level-off as shown in Figure 4-3. To accommodate this, a new expression used to describe the relationship between IRT and reagent dosage shows below.

$$
\text { IRT } \left.-\operatorname{IRT}_{\text {water }}=\operatorname{IRT}_{\infty} \exp \left(-\mathrm{K}_{\mathrm{d}} \mathrm{C}\right)\right)
$$


Table 4-1 Ultimate Froth Height and Volume Constant as a Function of Froth Concentration

\begin{tabular}{|c|c|c|c|c|c|c|}
\hline Collector & $\begin{array}{c}\text { Dosage } \\
(\mathrm{g} / \mathrm{L})\end{array}$ & $\begin{array}{l}\text { Ultimate } \\
\text { froth } \\
\text { height, } \\
\mathrm{H}_{0}(\mathrm{~cm})\end{array}$ & $\begin{array}{c}\text { Volume } \\
\text { constant } \\
\mathrm{K}_{\mathrm{f}} \\
(\mathrm{Min} / \mathrm{L})\end{array}$ & $\begin{array}{l}\text { IRT } \\
(\mathrm{s})\end{array}$ & $\begin{array}{c}\text { IDFI } \\
\mathrm{s.dm} / \mathrm{g}\end{array}$ & $\begin{array}{c}\text { IDFI }^{*} \mathrm{C} \\
\mathrm{s}\end{array}$ \\
\hline \multirow{5}{*}{ FA-12 } & 0.26 & 4.38 & 1.85 & 9.85 & \multirow{5}{*}{0.43} & 0.112 \\
\hline & 0.41 & 5.29 & 2.30 & 14.79 & & 0.176 \\
\hline & 0.49 & 6.58 & 5.43 & 43.43 & & 0.211 \\
\hline & 0.53 & 9.04 & 5.71 & 62.75 & & 0.228 \\
\hline & 0.60 & 15.37 & 5.36 & 100.15 & & 0.258 \\
\hline \multirow{5}{*}{ PA-31 } & 0.03 & 7.77 & 0.77 & 7.27 & \multirow{5}{*}{5.15} & 0.155 \\
\hline & 0.075 & 7.36 & 1.26 & 11.27 & & 0.386 \\
\hline & 0.09 & 7.49 & 2.41 & 21.94 & & 0.464 \\
\hline & 0.105 & 11.07 & 2.43 & 32.70 & & 0.541 \\
\hline & 0.12 & 13.81 & 4.64 & 77.89 & & 0.618 \\
\hline \multicolumn{2}{|c|}{ Water } & 21.79 & 0.18 & 4.77 & & \\
\hline
\end{tabular}




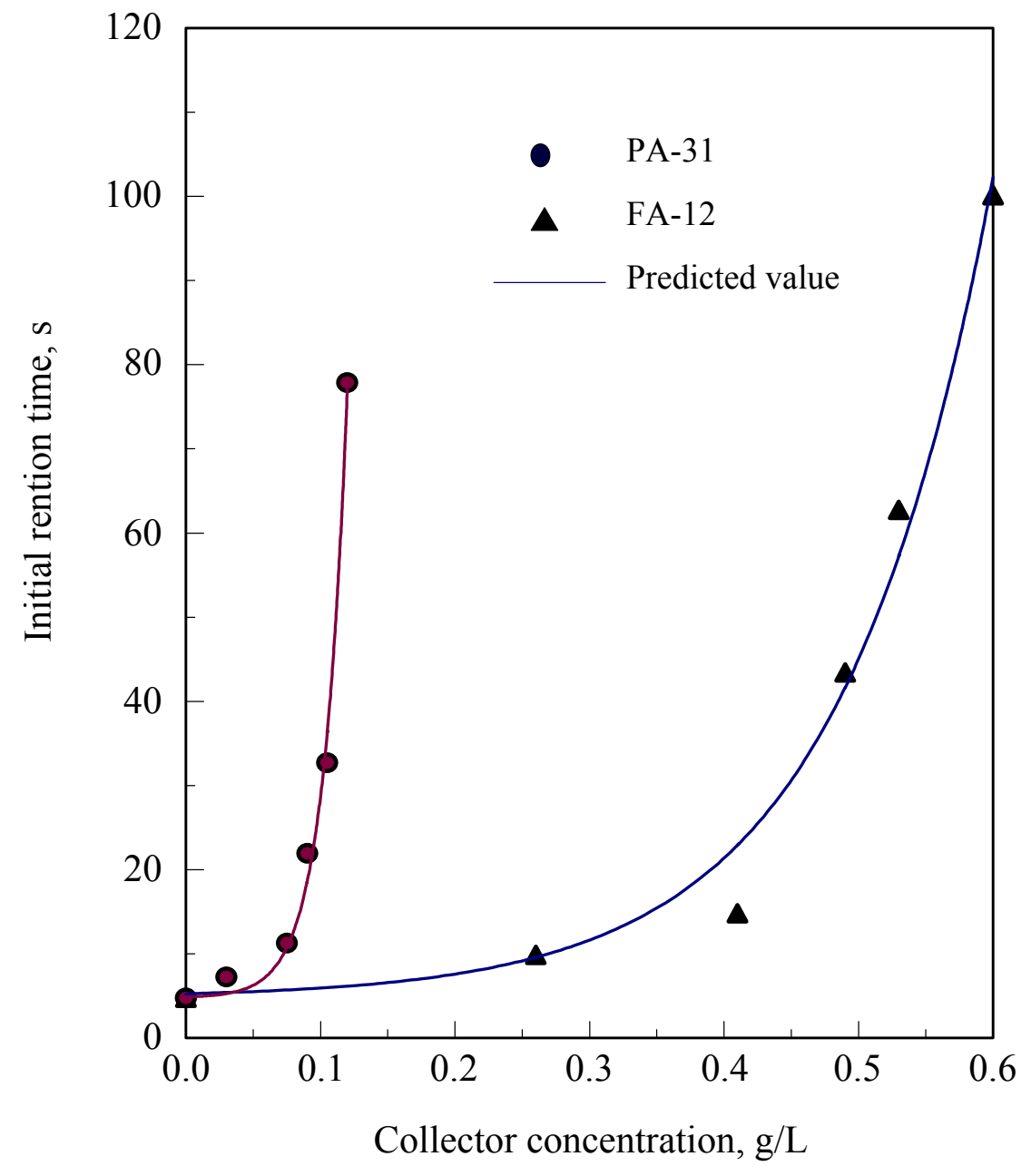

Figure 4-3 Initial Retention Time as a Function of Collector Concentration 
dynamic froth index, IDFI has been defined to describe the frothability characteristics of the reagents by Peng and Xia (2002). The IDFI is then obtained by the following equation:

$$
\mathrm{IDFI}=\left(\frac{\partial(\mathrm{IRT})}{\partial \mathrm{C}}\right)_{\mathrm{C} \rightarrow 0}=\mathrm{IRT}_{\infty} \mathrm{K}_{\mathrm{d}}
$$

The frother or collector requirements for mineral flotation use relatively low concentration. Applying Tyler series expression, Equation (4-4) can be reduced to

$$
\text { IRT - IRT } \text { water } \approx\left(\mathrm{RT}_{\infty} \cdot \mathrm{K}_{\mathrm{d}}\right) \cdot \mathrm{C}=\mathrm{IDFI} \cdot \mathrm{C}
$$

The product of IDFI and C represents the initial retention time difference between the reagent and the distilled water. The values of IRT, IDFI and IDFI*C are also included in Table 4-1. The product of the IDFI and collector concentration provides the information of the frothing properties for the reagents studied under dynamic steady state conditions. The results show that the value of IDFI is $0.43 \mathrm{~s} . \mathrm{dm}^{3} / \mathrm{g}$ for FA-12 and $5.5 \mathrm{s.dm} / \mathrm{g}$ for PA-31, respectively. Clearly, PA-31 has much stronger frothability than FA-12.

\subsection{Flotation Rate of Dolomite Phosphate Flotation}

The phosphate ore used for this study contained about $75 \%$ francolite, $10 \%$ dolomite and $15 \%$ other minerals. As usual practice in mineral processing, floating less and depressing bulk should be considered in order to reduce reagent consumption as well as operation cost. The francolite mineral has a hardness of 5 and dolomite 3.5 4. Therefore, dolomite is more fragile than francolite in grinding. That is to say that dolomite will accumulate in fine fractions after grinding. The typical size distribution and chemical analysis after grinding to minus $150 \mu \mathrm{m}$ (100 mesh) for flotation feed is shown in Table 4-2. 
Table 4-2 shows that the minus $38 \mu \mathrm{m}$ (400 mesh) fraction contains $3.46 \% \mathrm{MgO}$, much higher than in other fractions. The weight percentage of minus $38 \mu \mathrm{m}$ fraction is less than $50 \%$, but it contains more than $73 \%$ of total $\mathrm{MgO}$ in the feed. In order to separate dolomite from phosphate, usually dolomitic phosphate flotation is considered for several reasons. First, the amount of dolomite mineral is much less than that of phosphate. Less amount of mineral in the ore should be floated, and the bulk mineral should be kept in the sink, which is known as the principle of "floating less and depressing more" in practice. Secondly, dolomite should be floated because its particle size is much finer than phosphate. Generally, finer particles should be easier to float compared with coarse particles. Therefore, in most cases, dolomite flotation is widely accepted in processing dolomitic phosphate ores. Dolomite phosphate flotation rate was measured using FA-12 and PA-31 as collectors in this study. The chemical analysis results are given in Tables II-1, II-2, II-3, II-3, II-4, II-5 and II6 in Appendix II.

The performance of dolomitic phosphate flotation was analyzed using flotation rate constant and ultimate recovery. The model proposed by Huber-Penu et al. (1976) was used to describe the recovery of $\mathrm{MgO}$ in the float or sink as a function of time. Equation (4-2a) is for the float product, while Equation (4-2b) is for the sink product remained in the flotation cell.

$$
\begin{aligned}
& \mathrm{R}=\mathrm{R}_{\mathrm{m}}\left(1-\left(\frac{1}{\mathrm{Kt}}\right)(1-\exp (-\mathrm{Kt}))\right. \\
& \mathrm{R}=\mathrm{R}_{\mathrm{m}}\left(\frac{1}{\mathrm{Kt}}\right)(1-\exp (-\mathrm{Kt}))
\end{aligned}
$$

where $\mathrm{R}$ is the cumulative recovery of $\mathrm{MgO}$ in the float product, or $\mathrm{P}_{2} \mathrm{O}_{5}$ in the sink product at time $\mathrm{t}, \mathrm{R}_{\mathrm{m}}$ is the ultimate (equilibrium) recovery of $\mathrm{MgO}$ in the float product, or $\mathrm{P}_{2} \mathrm{O}_{5}$ in 
Table 4-2 Size Distribution and Chemical Analysis of Flotation Feed

\begin{tabular}{|c|c|c|c|c|c|}
\hline \multirow{2}{*}{$\begin{array}{c}\text { Size } \\
\mu \mathrm{m}(\mathrm{mesh})\end{array}$} & \multirow{2}{*}{$\begin{array}{c}\mathrm{Wt} . \\
(\%)\end{array}$} & \multicolumn{2}{|c|}{ Grade, \% } & \multicolumn{2}{c|}{ Recovery, \% } \\
\cline { 3 - 6 } & $\mathrm{P}_{2} \mathrm{O}_{5}$ & $\mathrm{MgO}$ & $\mathrm{P}_{2} \mathrm{O}_{5}$ & $\mathrm{MgO}$ \\
\hline$+106(+150)$ & 5.98 & 24.37 & 0.70 & 5.68 & 1.76 \\
\hline$-106+75(-150+200)$ & 18.69 & 25.96 & 1.04 & 18.86 & 8.33 \\
\hline$-75+63(-200+250)$ & 15.11 & 25.57 & 1.30 & 15.01 & 8.77 \\
\hline$-63+45(-250+325)$ & 3.57 & 25.20 & 1.36 & 3.50 & 2.19 \\
\hline$-45+38(-325+400)$ & 8.17 & 25.98 & 1.43 & 8.25 & 5.26 \\
\hline$-38(-400)$ & 48.49 & 25.81 & 3.46 & 48.70 & 73.69 \\
\hline Total & 100.00 & 25.71 & 2.28 & 100.00 & 100.00 \\
\hline
\end{tabular}

Table 4-3 Parameters of Dolomitic Phosphate Pebble Flotation Rate Models for $\mathrm{MgO}$ Recovery

\begin{tabular}{|c|c|c|c|}
\hline \multirow{2}{*}{ Parameters } & \multicolumn{3}{|c|}{ FA-12 Dosages $(\mathrm{kg} / \mathrm{t})$} \\
\cline { 2 - 4 } & 0.5 & 1.0 & 1.25 \\
\hline \multirow{2}{*}{$\mathrm{R}_{\mathrm{m}}$} & 63.77 & 80.83 & 84.23 \\
\hline $\mathrm{K}$ & 0.031 & 0.032 & 0.038 \\
\hline \multirow{2}{*}{ Parameters } & \multicolumn{3}{|c|}{ PA-31 Dosages $(\mathrm{kg} / \mathrm{t})$} \\
\cline { 2 - 4 } & 0.5 & 1.0 & 1.25 \\
\hline \multirow{2}{*}{$\mathrm{R}_{\mathrm{m}}$} & 68.61 & 86.31 & 85.79 \\
\hline $\mathrm{K}$ & 0.027 & 0.026 & 0.031 \\
\hline
\end{tabular}


the sink product at infinite flotation time, $\mathrm{K}$ is the rate constant of the recovery for $\mathrm{MgO}$ in the float, or $\mathrm{P}_{2} \mathrm{O}_{5}$ in the sink product.

The parameters $\mathrm{K}$ and $\mathrm{R}_{\mathrm{m}}$ in the flotation rate model were determined by using nonlinear regression analysis in PSIPLOT, and are given in Table 4-3. The dolomite flotation rate curves using FA-12 and PA-31 as collectors at various dosages are plotted in Figures 4-4 and 4-5 respectively. It can be seen that both collectors give similar dolomite flotation rate curves at same collector concentration. At each collector dosage, the curve shows a sharp increase between 0 and 3 minutes and then a gradual increase thereafter. With the increase of collector consumption, more dolomite was reported to the float product. At PA-31 collector dosage of $0.5 \mathrm{~kg} / \mathrm{t}$ of feed, only about $58 \% \mathrm{MgO}$ was removed to the float product at 6 minutes flotation time, while the PA-31 dosage was increased to $1.25 \mathrm{~kg} / \mathrm{t}, 78.67 \% \mathrm{MgO}$ was in the float product.

Figure 4-6 shows the comparison of the $\mathrm{MgO}$ recoveries in the float product using FA-12 and PA-31 as collectors at collector dosage of $1.0 \mathrm{~kg} / \mathrm{t}$ of feed. It can be seen that the $\mathrm{MgO}$ recovery is higher using FA-12 than with PA-31 initially. Two minutes later, the situation reverses. It indicates that more dolomite mineral could be recovered to the float product by increasing the flotation time for PA-31. Figure 4-7 plots the relationship between $\mathrm{P}_{2} \mathrm{O}_{5}$ recovery in the float product and flotation time. It can be seen that more $\mathrm{P}_{2} \mathrm{O}_{5}$ was misplaced to float product when FA-12 was used. Correspondingly, $\mathrm{P}_{2} \mathrm{O}_{5}$ recovery in the sink product was always lower than PA-31 when FA-12 was employed as a dolomite collector as shown in Figure4-8. Figure 4-9 shows that the sink product remained in the flotation cell contained higher $\mathrm{P}_{2} \mathrm{O}_{5}$ grade and lower $\mathrm{MgO}$ content when PA-31 was used as dolomite 


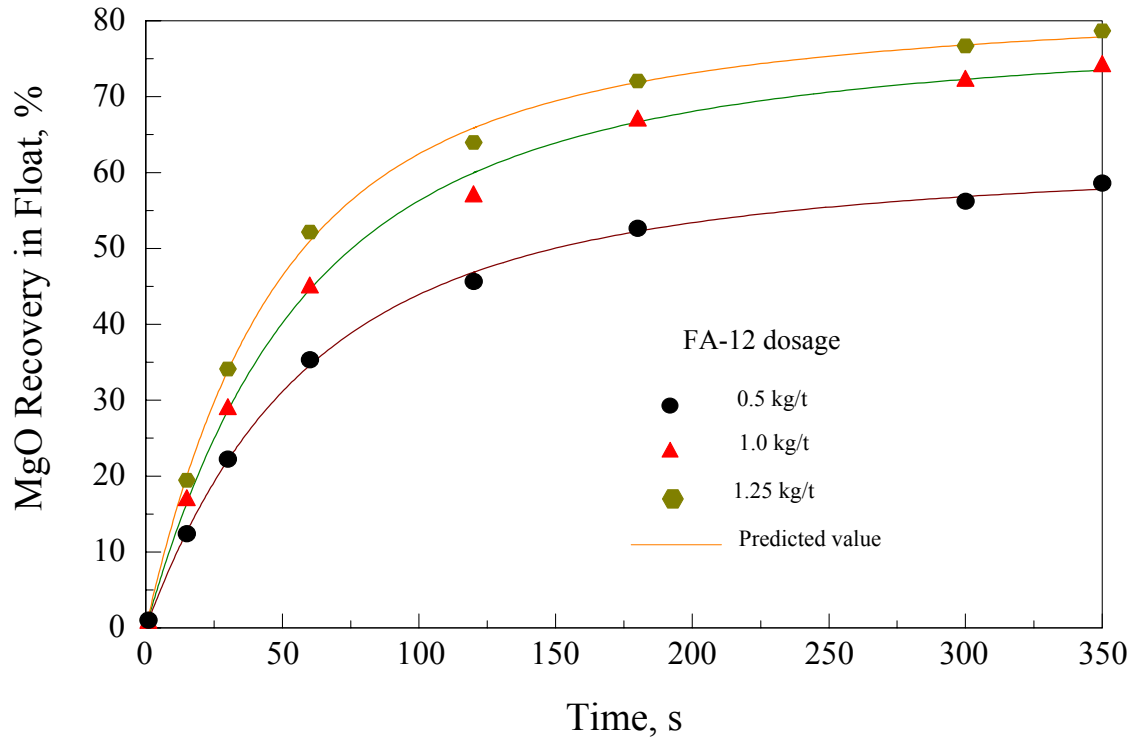

Figure 4-4 MgO Recovery as a Function of Time at Various FA-12 Collector Dosages

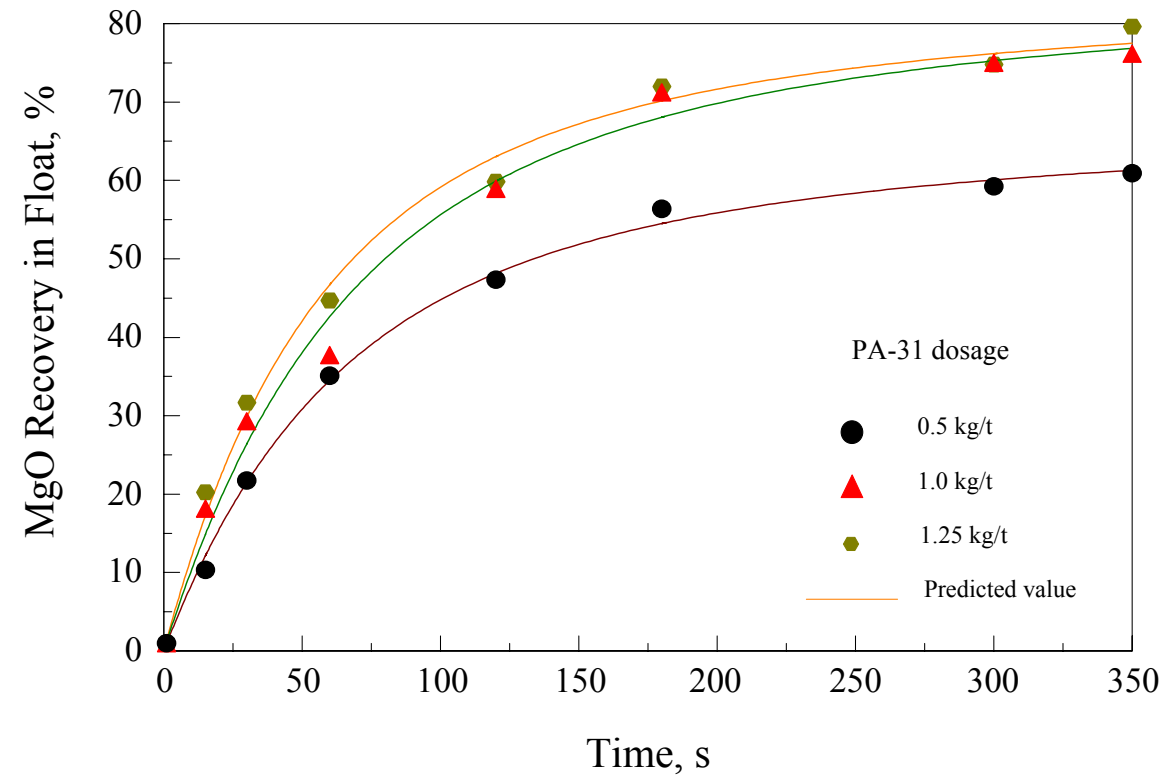

Figure 4-5 MgO Recovery as a Function of Time at Various PA-31 Collector Dosages 


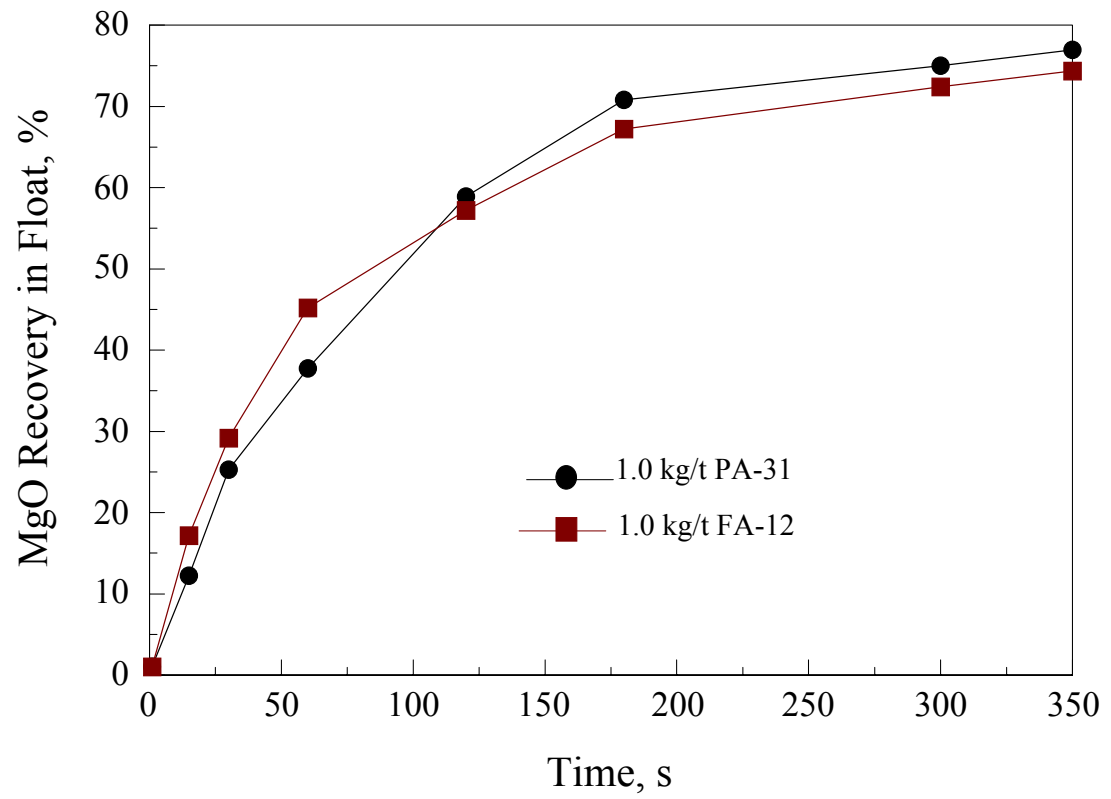

Figure 4-6 Dolomite Flotation Rate Comparison with FA-12 and PA-31 Collector at $1.0 \mathrm{~kg} / \mathrm{t}$

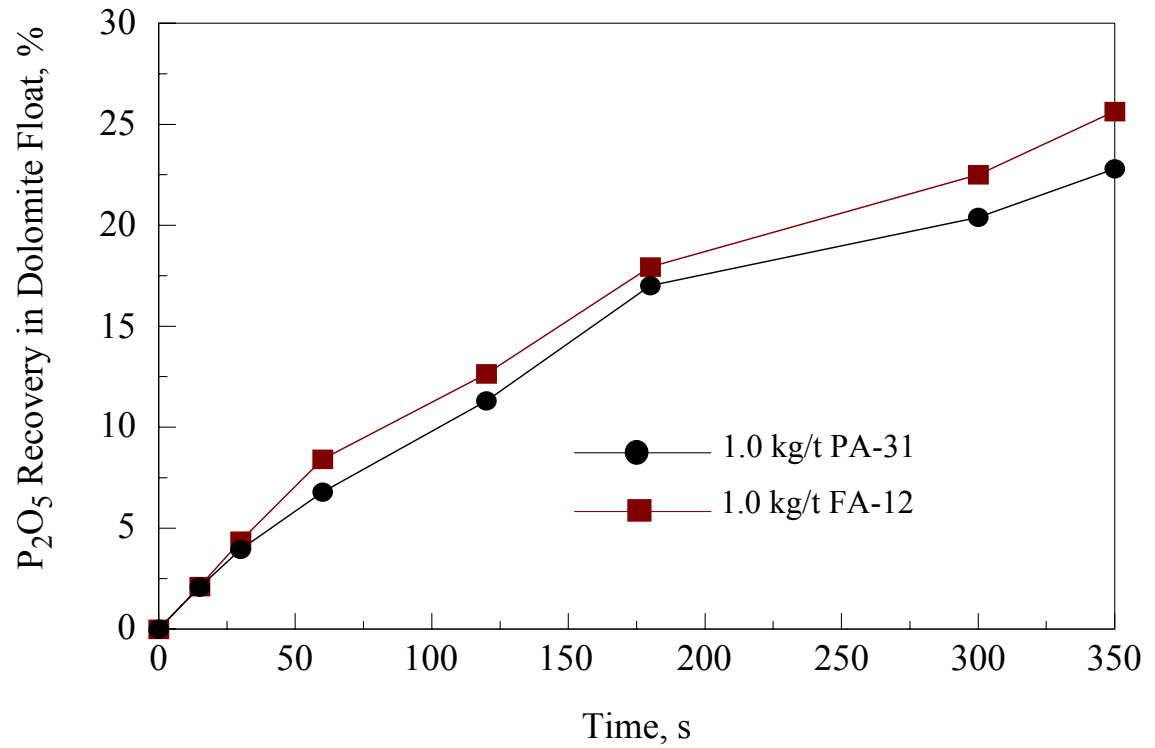

Figure 4-7 $\mathrm{P}_{2} \mathrm{O}_{5}$ Recovery in Dolomite Float as a Function of Flotation Time Using FA-12 and PA-31 Collector at $1.0 \mathrm{~kg} / \mathrm{t}$ 


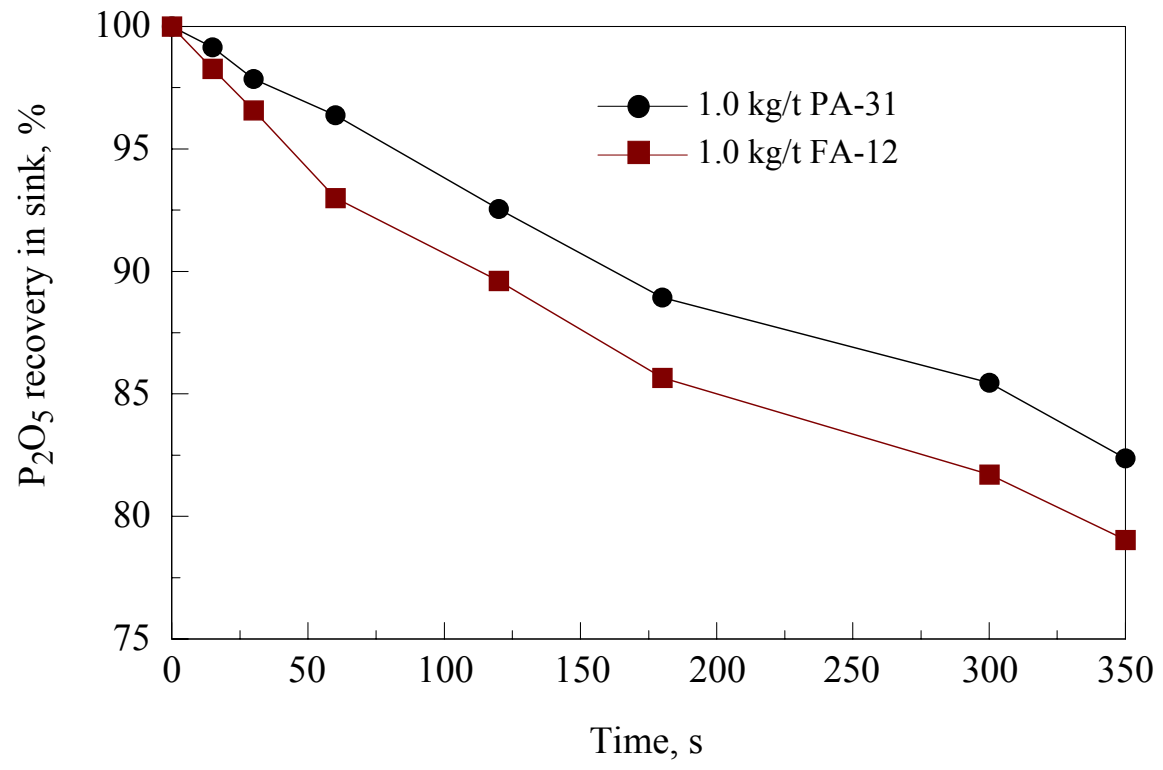

Figure 4-8 $\mathrm{P}_{2} \mathrm{O}_{5}$ Recovery in Sink Product as a Function of Flotation Time

Using FA-12 and PA-31 Collector at $1.0 \mathrm{~kg} / \mathrm{t}$

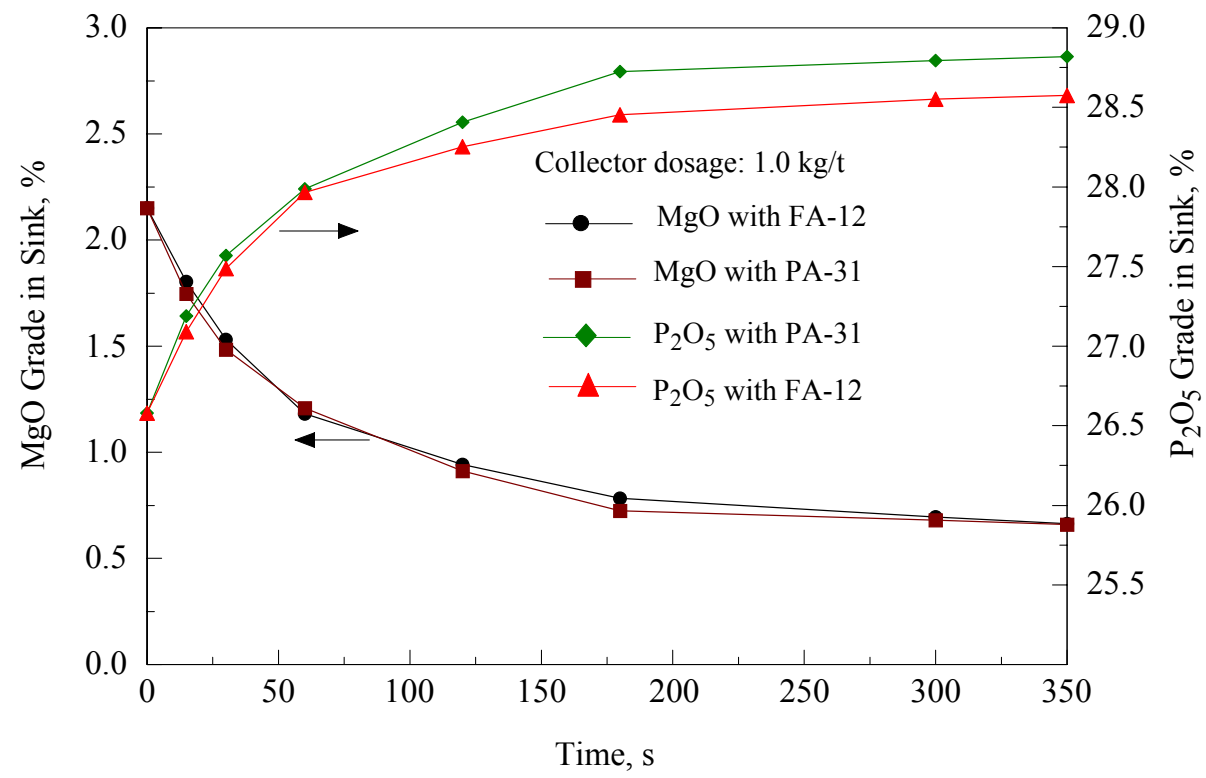

Figure 4-9 $\mathrm{MgO}$ and $\mathrm{P}_{2} \mathrm{O}_{5}$ Grade in the Sink Product as a Function of Flotation Time Using FA-12 and PA-31 Collector at $1.0 \mathrm{~kg} / \mathrm{t}$ 
collector. The results demonstrate that PA-31 has better selectivity than FA-12 in dolomite flotation.

\subsection{Dolomitic Phosphate Flotation with Denver D-12 Machine and 1.2 Liter Cell}

Dolomite flotation test was carried out in Denver D-12 flotation machine and 1.2 liter cell. In these flotation tests, the effects of $\mathrm{pH}$ and collector dosages were investigated, while impeller speed, aeration rate and solid percent of slurry were maintained at constant.

\subsubsection{Effect of $\mathrm{pH}$}

In addition to modifying flotation $\mathrm{pH}$, phosphoric acid could also work as a depressant for apatite by adsorbing on the surface of phosphate minerals to form calcium phosphate and preventing the adsorption of fatty acid. Usually, phosphoric acid could produce better performance by functioning as both $\mathrm{pH}$ modifier and phosphate ore depressant in dolomite flotation. Sulfuric acid was used to substitute some phosphoric acid for the purpose of reducing the total reagent cost.

The dolomite flotation tests were carried out in $\mathrm{pH}$ range from 4.6 to 6 at the collector dosage of $1.0 \mathrm{~kg} / \mathrm{t}$ of feed and the results are summarized in Table 4-4. The effect of $\mathrm{pH}$ on dolomitic phosphate flotation is plotted in Figure 4-10. With the increase of $\mathrm{pH}$, the overall $\mathrm{P}_{2} \mathrm{O}_{5}$ recovery decreased. It indicates that more phosphate was reported to tailings at higher pH. Between $\mathrm{pH} 5$ and $\mathrm{pH} 5.5$, the phosphate sink had a highest $\mathrm{P}_{2} \mathrm{O}_{5}$ content. At $\mathrm{pH} 5.5$, the

flotation sink product contained lowest $\mathrm{MgO}$. The selectivity index was used as a criterion to 
determine the optimum $\mathrm{pH}$ value at 5.5 for dolomitic phosphate flotation. Table 4-4 shows the SIp has maximum value of 68.98 .

\subsubsection{Effect of Collector Dosages on Dolomite Flotation}

A series of tests were conducted to determine the optimum consumption of collector at $\mathrm{pH}$ 5.5, and the results are shown in Table 4-5. The effect of PA-31 dosages on dolomitic phosphate flotation is presented in Figure 4-11. The results in Figure 4-11 show that at low collector dosage, the sink product had low $\mathrm{P}_{2} \mathrm{O}_{5}$ grade and high $\mathrm{MgO}$ content, while the $\mathrm{P}_{2} \mathrm{O}_{5}$ and $\mathrm{MgO}$ recoveries in float product were at high level. With the increase of collector dosage, the $\mathrm{P}_{2} \mathrm{O}_{5}$ grade in the sink product increased, while both $\mathrm{MgO}$ grade and $\mathrm{P}_{2} \mathrm{O}_{5}$ recovery decreased. It is difficult to further reduce the $\mathrm{MgO}$ grade to less than $0.6 \%$ and increase the $\mathrm{P}_{2} \mathrm{O}_{5}$ grade in the sink product by increasing collector dosage. This can be explained by the fact that there is about $0.45 \%$ to $0.50 \% \mathrm{MgO}$ in the lattice of apatite that can not be rejected through physical separation method such as froth flotation technology. There is also about $10 \% \mathrm{SiO}_{2}$ in the dolomitic phosphate pebble sample that needs to be removed through other procedure such a silica flotation using fatty acid amine as collector.

\subsubsection{Correlation of $\mathrm{MgO}$ Grade and $\mathrm{P}_{2} \mathrm{O}_{5}$ Recovery in Sink Product of Dolomitic Flotation}

All the test results with Denver 1.2 liter flotation cell are summarized and plotted in Figure 4-12 to illustrate the relationship between the $\mathrm{MgO}$ and $\mathrm{P}_{2} \mathrm{O}_{5}$ grades and $\mathrm{P}_{2} \mathrm{O}_{5}$ recovery. The $\mathrm{P}_{2} \mathrm{O}_{5}$ grade and recovery changed with $\mathrm{MgO}$ grade in sink product. The higher 
Table 4-4 pH Effect on Dolomitic Phosphate Flotation Using Denver D-12 Machine and 1.2 Liter Cell

\begin{tabular}{|c|c|c|c|c|c|c|c|}
\hline \multirow{2}{*}{ PH } & \multirow{2}{*}{ Product } & Wt. & \multicolumn{2}{|c|}{ Grade (\%) } & \multicolumn{2}{|c|}{ Recovery (\%) } & \multirow{3}{*}{ SI } \\
\cline { 3 - 7 } & & $\mathrm{P}_{2} \mathrm{O}_{5}$ & $\mathrm{MgO}$ & $\mathrm{P}_{2} \mathrm{O}_{5}$ & $\mathrm{MgO}$ & \\
\hline \multirow{4}{*}{4.6} & Dolomite float & 9.88 & 12.25 & 11.88 & 4.54 & 56.16 & \\
\cline { 2 - 7 } & Phosphate sink & 90.12 & 28.24 & 1.02 & 95.46 & 43.84 & 62.11 \\
\cline { 2 - 7 } & Head & 100.00 & 26.66 & 2.09 & 100.00 & 100.00 & \\
\hline \multirow{4}{*}{5.1} & Dolomite float & 12.78 & 13.17 & 11.26 & 6.28 & 67.24 & \\
\cline { 2 - 7 } & Phosphate sink & 87.22 & 28.81 & 0.80 & 93.72 & 32.76 & 67.55 \\
\cline { 2 - 7 } & Head & 100.00 & 26.81 & 2.14 & 100.00 & 100.00 & \\
\hline \multirow{4}{*}{5.5} & Dolomite float & 13.86 & 14.00 & 10.99 & 7.25 & 71.51 & \\
\cline { 2 - 7 } & Phosphate sink & 86.14 & 28.80 & 0.70 & 92.75 & 28.49 & 68.98 \\
\cline { 2 - 7 } & Head & 100.00 & 26.75 & 2.13 & 100.00 & 100.00 & \\
\hline \multirow{4}{*}{6.0} & Dolomite float & 17.55 & 18.84 & 7.82 & 12.36 & 65.35 & \\
\cline { 2 - 7 } & Phosphate sink & 82.45 & 28.43 & 0.88 & 87.64 & 34.65 & 60.51 \\
\cline { 2 - 6 } & Head & 100.00 & 26.75 & 2.10 & 100.00 & 100.00 & \\
\hline
\end{tabular}

Operation conditions: Collector dosage: $1.0 \mathrm{~kg} / \mathrm{t}$ feed

Impeller speed of flotation machine: $1100 \mathrm{rpm}$

Solid of slurry: $25 \%$ 


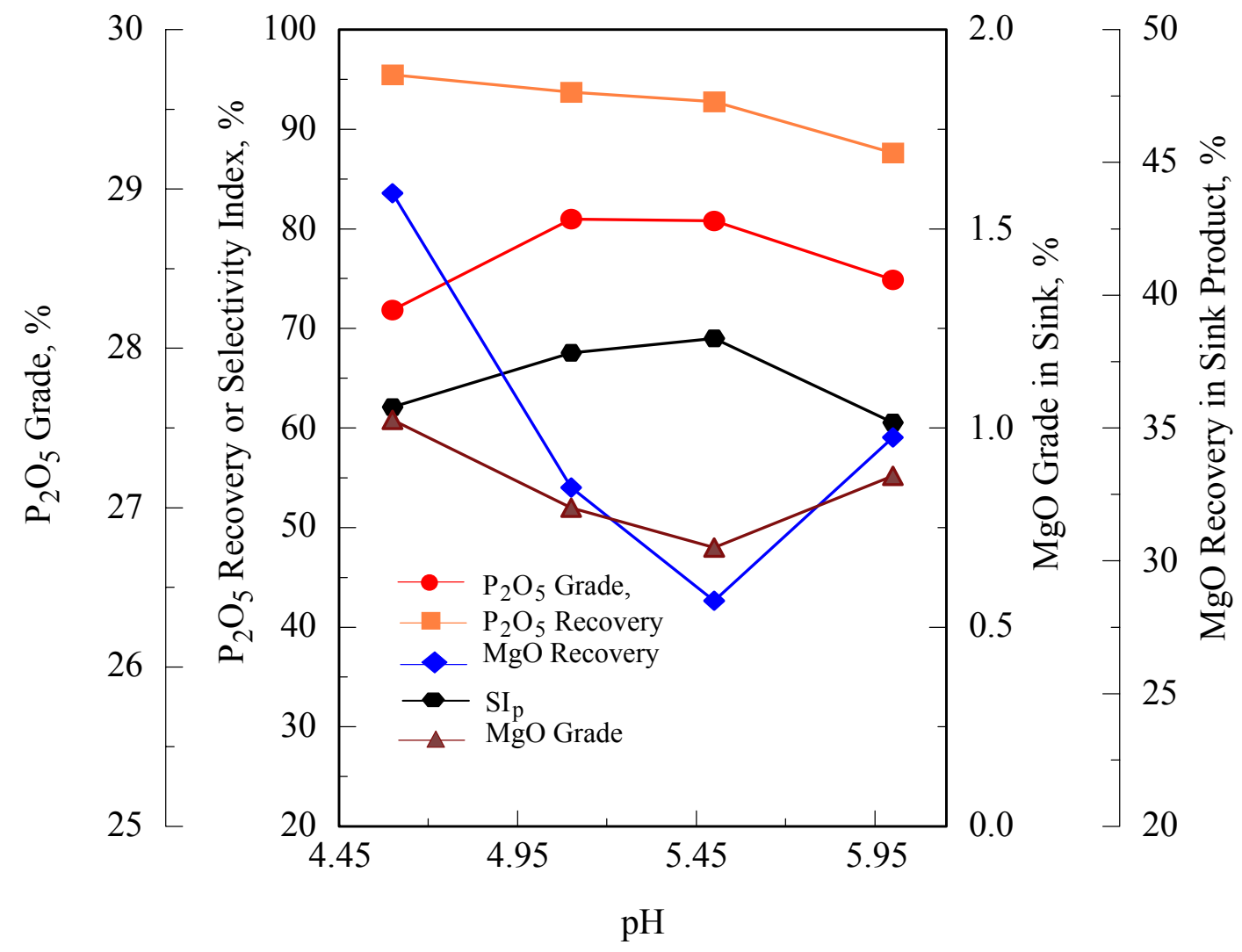

Figure 4-10 Effect of Flotation $\mathrm{pH}$ on the Recovery and Grade of $\mathrm{P}_{2} \mathrm{O}_{5}$ and $\mathrm{MgO}$ in Concentrate (Sink Product) 
Table 4-5 Collector Dosage Effect on Dolomitic Phosphate Flotation Using Denver D-12 Machine and 1.2 Liter Cell

\begin{tabular}{|c|c|c|c|c|c|c|c|}
\hline \multirow{2}{*}{$\begin{array}{l}\text { Collector } \\
\text { (kg/t feed) }\end{array}$} & \multirow{2}{*}{ Product } & \multirow{2}{*}{$\begin{array}{l}\mathrm{Wt} . \\
\%\end{array}$} & \multicolumn{2}{|c|}{ Grade, $\%$} & \multicolumn{2}{|c|}{ Recovery, \% } & \multirow{2}{*}{ SI } \\
\hline & & & $\mathrm{P}_{2} \mathrm{O}_{5}$ & $\mathrm{MgO}$ & $\mathrm{P}_{2} \mathrm{O}_{5}$ & $\mathrm{MgO}$ & \\
\hline \multirow{3}{*}{0.6} & Dolomite float & 10.78 & 11.51 & 11.37 & 4.66 & 59.79 & \multirow{3}{*}{64.35} \\
\hline & Phosphate sink & 89.22 & 28.42 & 0.92 & 95.34 & 40.21 & \\
\hline & Head & 100.00 & 26.60 & 2.05 & 100.00 & 100.00 & \\
\hline \multirow{3}{*}{0.8} & Dolomite float & 12.81 & 13.49 & 11.27 & 6.47 & 69.08 & \multirow{3}{*}{68.17} \\
\hline & Phosphate sink & 87.19 & 28.63 & 0.74 & 93.53 & 30.92 & \\
\hline & Head & 100.00 & 26.69 & 2.09 & 100.00 & 100.00 & \\
\hline \multirow{3}{*}{1.0} & Dolomite float & 13.86 & 14.00 & 10.99 & 7.25 & 71.51 & \multirow{3}{*}{68.98} \\
\hline & Phosphate sink & 86.14 & 28.80 & 0.70 & 92.75 & 28.49 & \\
\hline & Head & 100.00 & 26.75 & 2.13 & 100.00 & 100.00 & \\
\hline \multirow{3}{*}{1.25} & Dolomite float & 17.72 & 17.22 & 8.87 & 11.35 & 75.57 & \multirow{3}{*}{67.62} \\
\hline & Phosphate sink & 82.28 & 28.97 & 0.62 & 88.65 & 24.43 & \\
\hline & Head & 100.00 & 26.89 & 2.08 & 100.00 & 100.00 & \\
\hline
\end{tabular}

Operation conditions: Flotation $\mathrm{pH}: 5.5$

Impeller speed of flotation machine: $1100 \mathrm{rpm}$

Solid of slurry: $25.0 \%$ 


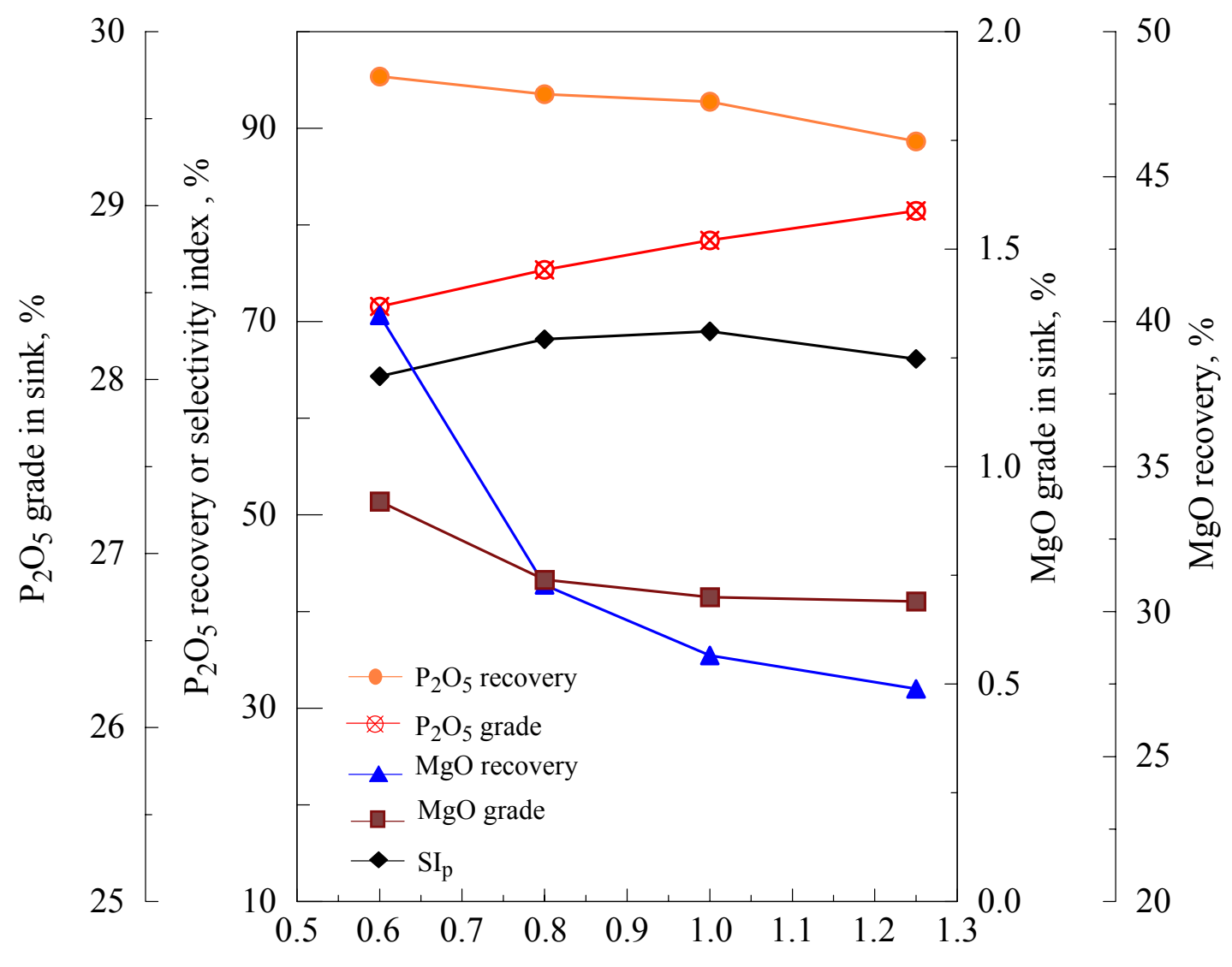

Collector dosage, $\mathrm{kg} / \mathrm{t}$ feed

Figure 4-11 Effect of Collector Dosages on Dolomite Flotation Performance 
$\mathrm{P}_{2} \mathrm{O}_{5}$ recovery in sink could be achieved while $\mathrm{MgO}$ content increased, but $\mathrm{P}_{2} \mathrm{O}_{5}$ grade decreased due to that more dolomite mineral remained in the sink. The sink product of dolomite flotation containing about $28.8 \% \mathrm{P}_{2} \mathrm{O}_{5}$ and $0.7 \% \mathrm{MgO}$ was obtained at $92.75 \%$ $\mathrm{P}_{2} \mathrm{O}_{5}$ recovery. For producing a phosphate concentrate with more than $30 \% \mathrm{P}_{2} \mathrm{O}_{5}$ and $1 \%$ $\mathrm{MgO}$, amine flotation must be employed to further remove silica. In amine flotation, little dolomite can be floated with quartz due to that the amine collector will not absorb on dolomite surface. That is to say nearly all dolomite in dolomite flotation sink product will remain in final concentrate after amine flotation. In order for the final phosphate concentrate to contain less than $1 \% \mathrm{MgO}$, the $\mathrm{MgO}$ grade in the sink product should be less than $0.8 \%$ after dolomite flotation.

\subsubsection{Silica Flotation}

After dolomitic phosphate flotation, the sink product with $28.8 \% \mathrm{P}_{2} \mathrm{O}_{5}$ and $0.7 \%$ $\mathrm{MgO}$ contents and $92.75 \%$ recovery was obtained, but the product could not meet the market specification. The $\mathrm{P}_{2} \mathrm{O}_{5}$ grade needs to be further upgraded to over $30 \%$ by reject silica impurity. Using fatty acid amine to float quartz is the common practice in Florida phosphate industry. However, amine collector is extremely sensitive to slimes in the process. In this study, the flotation feed is $100 \%$ passing $150 \mu \mathrm{m}$ (100 mesh). After dolomitic phosphate flotation, the sink product still contained considerable amount of fine particles finer than $38 \mu \mathrm{m}$ (400 mesh). This means that the amine flotation of this sample might not perform well for separating silica from phosphate without desliming. The size distribution and chemical analysis for the sink product of dolomitic phosphate flotation are tabulated in Table 4-6. 


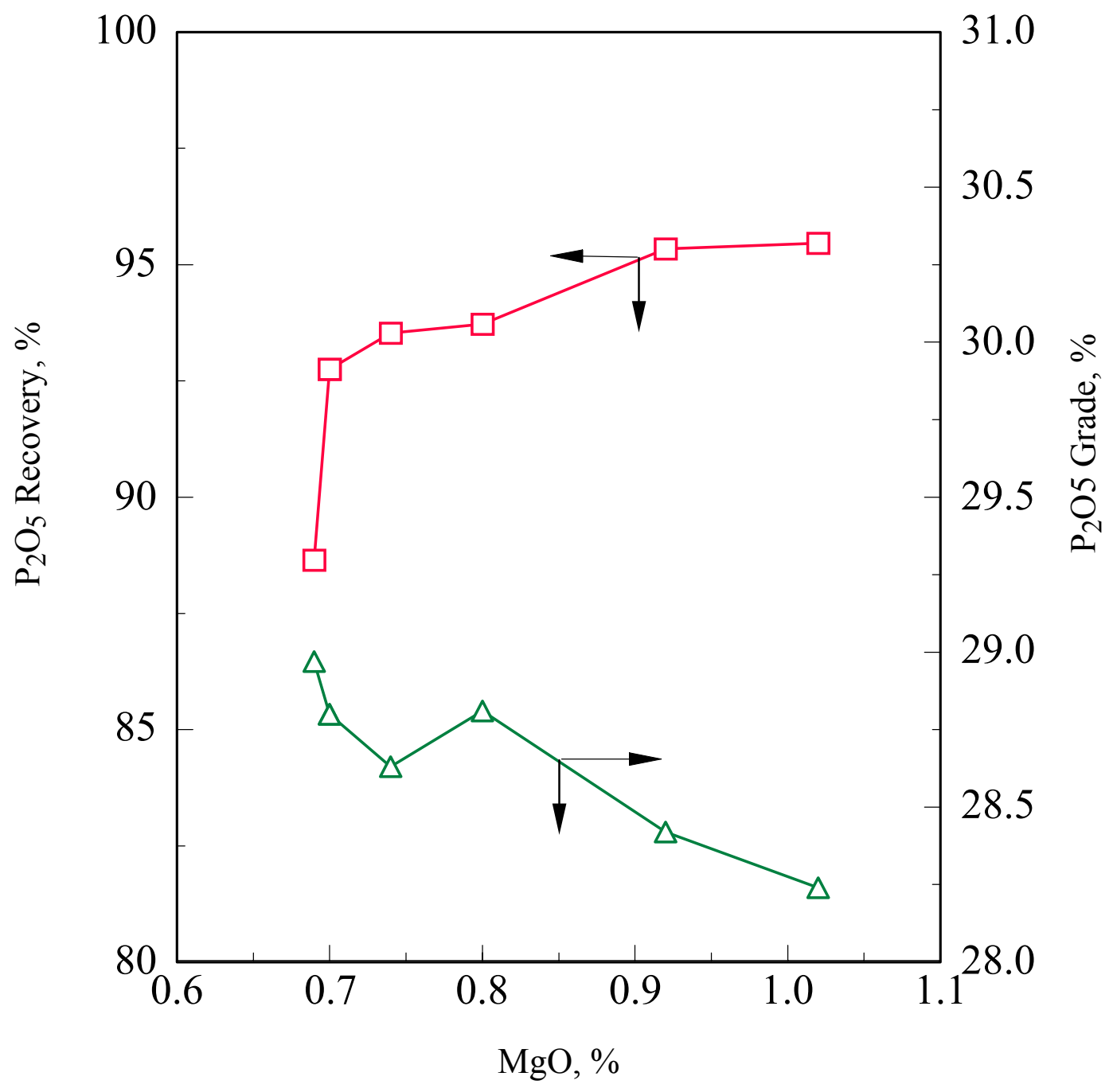

Figure 4-12 Relationship between $\mathrm{MgO}$ and $\mathrm{P}_{2} \mathrm{O}_{5}$ Grade and $\mathrm{P}_{2} \mathrm{O}_{5}$ Recovery in the Sink Product of Dolomitic Phosphate Flotation 
Table 4-6 shows that the sink product contained less than $1 \% \mathrm{MgO}$ for all size fractions. Although the minus $-38 \mu \mathrm{m}$ size fraction had higher $\mathrm{MgO}$ than other fractions, the $\mathrm{P}_{2} \mathrm{O}_{5}$ in this size fraction was also higher because the ultra fines contain much lower silica. Therefore, the minus $-38 \mu \mathrm{m}$ fines could be treated as a final product without further treatment. In this approach, not only the usage of amine dosage was reduced, but also the effectiveness of amine flotation could be significantly improved.

The sink product of dolomitic phosphate flotation was sized at $38 \mu \mathrm{m}$. The plus 38 $\mu \mathrm{m}$ size fraction was diluted in Denver flotation cell. Sodium carbonate at dosage of $0.3 \mathrm{~kg} / \mathrm{t}$ of feed was used to adjust $\mathrm{pH}$ to neutral or slightly alkaline $(\mathrm{pH} 7 \sim 8)$. Previous experiments demonstrated that the utilization of sodium carbonate as $\mathrm{pH}$ modifier in amine flotation stage could minimize the effect of calcium and magnesium ions on amine flotation performance by forming calcium and magnesium carbonates. After $\mathrm{pH}$ adjustment, $0.4 \mathrm{~kg}$ amine and $0.1 \mathrm{~kg}$ kerosene per ton of feed were added as collector for silica flotation. The material balance for dolomite flotation and silica flotation is given in Table 4-7.

The data in Table 4-7 show that the flotation concentrate with $32.39 \% \mathrm{P}_{2} \mathrm{O}_{5}$ and $0.71 \% \mathrm{MgO}$ by amine flotation could be obtained from plus $38 \mu \mathrm{m}$ (400 mesh) size fraction of dolomite flotation sink product. The sink product of fatty acid amine flotation was then combined with minus $38 \mu \mathrm{m}$ fines to form a composite concentrate, which had $31.66 \% \mathrm{P}_{2} \mathrm{O}_{5}$ and $0.79 \% \mathrm{MgO}$ at the overall $\mathrm{P}_{2} \mathrm{O}_{5}$ recovery of $92 \%$. The feed used in the experiment had $26.68 \% \mathrm{P}_{2} \mathrm{O}_{5}$ and $2.14 \% \mathrm{MgO}$.

Laboratory tests and industrial operation demonstrated that PA-31 gave high selectivity for dolomite flotation. Lu and Sun (1998) reported that a phosphate concentrate 
Table 4-6 Size Distribution and Chemical Analysis of the Sink Product of Dolomitic Phosphate Flotation

\begin{tabular}{|c|c|c|c|c|c|}
\hline \multirow{2}{*}{$\begin{array}{c}\text { Size } \\
\mu \mathrm{m}(\mathrm{mesh})\end{array}$} & \multirow{2}{*}{$\mathrm{Wt.} \%$} & \multicolumn{2}{|c|}{ Grade, \% } & \multicolumn{2}{c|}{ Recovery, \% } \\
\cline { 3 - 6 } & & $\mathrm{P}_{2} \mathrm{O}_{5}$ & $\mathrm{MgO}$ & $\mathrm{P}_{2} \mathrm{O}_{5}$ & $\mathrm{MgO}$ \\
\hline$+105(+150)$ & 6.45 & 26.25 & 0.65 & 5.95 & 5.59 \\
\hline$-105+75(-150+200)$ & 23.32 & 27.42 & 0.61 & 22.48 & 18.97 \\
\hline$-75+63(-200+250)$ & 18.94 & 27.68 & 0.60 & 18.43 & 15.16 \\
\hline$-63+45(-250+325)$ & 7.64 & 28.63 & 0.67 & 7.69 & 6.83 \\
\hline$-45+38(-325+400)$ & 8.45 & 28.88 & 0.66 & 8.58 & 7.44 \\
\hline$-38(-400)$ & 35.20 & 29.80 & 0.98 & 36.87 & 46.01 \\
\hline Total & 100.00 & 28.45 & 0.75 & 100.00 & 100.00 \\
\hline
\end{tabular}

Table 4-7 Material Balance of Dolomitic Phosphate Flotation and Amine Flotation Using Denver Stirrer Tank Cell

\begin{tabular}{|c|c|c|c|c|c|c|c|}
\hline \multirow{2}{*}{ Product } & \multirow{2}{*}{ Wt. \% } & \multicolumn{3}{|c|}{ Grade, \% } & \multicolumn{3}{c|}{ Recovery, \% } \\
\cline { 3 - 8 } & & $\mathrm{P}_{2} \mathrm{O}_{5}$ & $\mathrm{MgO}$ & $\mathrm{SiO}_{2}$ & $\mathrm{P}_{2} \mathrm{O}_{5}$ & $\mathrm{MgO}$ & $\mathrm{SiO}_{2}$ \\
\hline Dolomite float & 13.86 & 14.00 & 10.99 & 4.09 & 7.27 & 71.25 & 5.20 \\
\hline Silica float & 8.48 & 1.80 & 0.05 & 90.15 & 0.57 & 0.20 & 70.14 \\
\hline Silica sink & 55.86 & 32.39 & 0.71 & 1.97 & 67.82 & 18.55 & 10.10 \\
\hline$-38 \mu \mathrm{m}$ (-400 mesh) & 21.80 & 29.80 & 0.98 & 7.28 & 24.35 & 9.99 & 14.56 \\
\hline Head & 100.00 & 26.68 & 2.14 & 10.90 & 100.00 & 100.00 & 100.00 \\
\hline Composite Conc.* & 77.66 & 31.66 & 0.79 & 3.46 & 92.17 & 28.54 & 24.66 \\
\hline
\end{tabular}

* Composite concentrate is formed by combining the sink product of fatty acid amine flotation with minus $-38 \mu \mathrm{m}$ (-400 mesh) of dolomite flotation. 
containing $36 \%$ of $\mathrm{P}_{2} \mathrm{O}_{5}$ and less than $1 \% \mathrm{MgO}$ has been obtained at the overall $\mathrm{P}_{2} \mathrm{O}_{5}$ recovery of more than $95 \%$ from the feed of $29-31 \% \mathrm{P}_{2} \mathrm{O}_{5}$ and about $4 \% \mathrm{MgO}$. Despite of Florida dolomitic phosphate pebble sample has lower $\mathrm{P}_{2} \mathrm{O}_{5}$ and $\mathrm{MgO}$ contents, the results from this study show that the separation performance of dolomite flotation using PA-31 collector is compatible with that of $\mathrm{Lu}$ et al. (1998). This shows that the dolomite flotation using PA-31 responses well to the phosphate ores from different sources.

\subsection{Packed Column Flotation}

\subsubsection{Packed Column Flotation Results}

The operation parameters for packed column flotation included collector dosage, $\mathrm{pH}$, feed rate, feed solid concentration, froth height (interface), air flow rate and wash water rate. The experiment designs used to conduct the experiment were described in Section 3-5. The packed column flotation results according to fractional factorial design I, step-one experiment are shown in Table 4-8. The Selectivity Index SIp calculated based on Equation (3-4) was used to represent the flotation response for each flotation test. The estimates associated with the linear combinations of the factor effects were obtained by multiplying each column of plus and minus signs in the base design calculation matrix by the column of the flotation response, SIp, summing them and then dividing by [(No. of runs)/2]. As an example, the estimate of collector effect, $\mathrm{E}_{\mathfrak{c}}$ in fractional factorial design $\mathrm{I}$, step-one experiment can be made as follows:

$$
\mathrm{E}_{\mathrm{a}}=\text { Contrasts }_{\mathrm{a}} /(\mathrm{N} / 2)=\left(\mathrm{SI}_{5}+\mathrm{SI}_{6}+\mathrm{SI}_{7}+\mathrm{SI}_{8}-\mathrm{SI}_{1}-\mathrm{SI}_{2}-\mathrm{SI}_{3}-\mathrm{SI}_{4}\right) /(8 / 2)
$$




$$
\begin{aligned}
& =(49.85+56.45+57.29+59.93-48.73-52.35-50.41-48.88) / 4 \\
& =(223.52-200.37) / 4 \\
& =5.79
\end{aligned}
$$

Table 4-9 presents the main effects estimated using SIp as flotation response for all factors in factorial design I, step-one experiment. Figure 4-13 displays a normal probability plot of the estimates given above. $\mathrm{X}$ axis denotes the effect estimate of all factors in an order from smallest to largest, and $\mathrm{Y}$ axis represents the probability calculated by $100 *[(\mathrm{j}-0.5) / \mathrm{n}]$, where $\mathrm{j}$ is the order number of $\mathrm{jth}$ effect and $\mathrm{n}$ is the total number of factors. Due to the minimum runs were carried out, only main effects could be estimated, the effect estimates are not well normally distributed. An examination of the normal probability plot reveals that five factors are important because the absolute values of their effect estimates are relatively large. Those main effects may be interpreted as follows:

(1) Main effect of $\mathrm{pH}$ : The higher level of $\mathrm{pH}$ value yields an effect of SIp value 7.04 higher than the low level of $\mathrm{pH}$ value. This effect is the largest relative to others. It means $\mathrm{pH}$ should be further increased.

(2) Main effect of collector dosage: $1.3 \mathrm{~kg} / \mathrm{t}$ PA-31 dosage yields an effect of SIp value 5.79 higher than $1.0 \mathrm{~kg} / \mathrm{t} \mathrm{PA}-31$. It indicates that more collector is needed for the next set of experiment.

(3) Main effect of feed rate: $300 \mathrm{~mL} / \mathrm{min}$ feed rate yields an effect of SIp value 4.02 higher than a feed rate of $250 \mathrm{~mL} / \mathrm{min}$. It shows that the feed rate can be increased further. 
Table 4-8 Dolomitic Phosphate Flotation Results Based on Factorial Design I, Step-one Experiment

\begin{tabular}{|c|c|c|c|c|c|c|c|}
\hline \multirow{2}{*}{$\begin{array}{l}\text { Test } \\
\text { No. }\end{array}$} & \multirow{2}{*}{ Product } & \multirow{2}{*}{ Wt. $\%$} & \multicolumn{2}{|c|}{ Grade, $\%$} & \multicolumn{2}{|c|}{ Recovery, \% } & \multirow{2}{*}{$\begin{array}{c}\text { Response } \\
\text { SIp }\end{array}$} \\
\hline & & & $\mathrm{P}_{2} \mathrm{O}_{5}$ & $\mathrm{MgO}$ & $\mathrm{P}_{2} \mathrm{O}_{5}$ & $\mathrm{MgO}$ & \\
\hline \multirow{3}{*}{1} & Float & 5.81 & 11.40 & 12.44 & 2.48 & 34.25 & \multirow{3}{*}{48.73} \\
\hline & Sink & 94.19 & 27.64 & 1.47 & 97.52 & 65.75 & \\
\hline & Head & 100.00 & 26.70 & 2.11 & 100.00 & 100.00 & \\
\hline \multirow{3}{*}{2} & Float & 7.23 & 12.18 & 11.65 & 3.30 & 40.11 & \multirow{3}{*}{52.35} \\
\hline & Sink & 92.77 & 27.78 & 1.36 & 96.70 & 59.89 & \\
\hline & Head & 100.00 & 26.65 & 2.10 & 100.00 & 100.00 & \\
\hline \multirow{3}{*}{3} & Float & 6.48 & 12.08 & 11.81 & 2.93 & 36.97 & \multirow{3}{*}{50.41} \\
\hline & Sink & 93.52 & 27.73 & 1.40 & 97.07 & 63.03 & \\
\hline & Head & 100.00 & 26.72 & 2.07 & 100.00 & 100.00 & \\
\hline \multirow{3}{*}{4} & Float & 6.65 & 11.88 & 11.34 & 2.97 & 35.07 & \multirow{3}{*}{48.88} \\
\hline & Sink & 93.35 & 27.66 & 1.50 & 97.03 & 64.93 & \\
\hline & Head & 100.00 & 26.61 & 2.15 & 100.00 & 100.00 & \\
\hline \multirow{3}{*}{5} & Float & 6.54 & 11.86 & 11.84 & 2.92 & 36.35 & \multirow{3}{*}{49.85} \\
\hline & Sink & 93.46 & 27.61 & 1.45 & 97.08 & 63.65 & \\
\hline & Head & 100.00 & 26.58 & 2.13 & 100.00 & 100.00 & \\
\hline \multirow{3}{*}{6} & Float & 9.12 & 12.86 & 10.98 & 4.40 & 47.23 & \multirow{3}{*}{56.45} \\
\hline & Sink & 90.88 & 28.07 & 1.23 & 95.60 & 52.77 & \\
\hline & Head & 100.00 & 26.68 & 2.12 & 100.00 & 100.00 & \\
\hline \multirow{3}{*}{7} & Float & 9.09 & 12.98 & 11.03 & 4.41 & 48.44 & \multirow{3}{*}{57.29} \\
\hline & Sink & 90.91 & 28.13 & 1.17 & 95.59 & 51.56 & \\
\hline & Head & 100.00 & 26.75 & 2.07 & 100.00 & 100.00 & \\
\hline \multirow{3}{*}{8} & Float & 10.44 & 13.01 & 10.85 & 5.10 & 53.43 & \multirow{3}{*}{59.93} \\
\hline & Sink & 89.56 & 28.24 & 1.10 & 94.90 & 46.57 & \\
\hline & Head & 100.00 & 26.65 & 2.12 & 100.00 & 100.00 & \\
\hline
\end{tabular}


Table 4-9 Main Effects of the Factors for Factorial Design I, Step-one Experiment

\begin{tabular}{|l|c|}
\hline \multicolumn{1}{|c|}{ Factors } & Effect \\
\hline Collector & 5.79 \\
\hline PH & 7.04 \\
\hline Feed rate & 4.02 \\
\hline Feed solid & -0.19 \\
\hline Interface & -5.23 \\
\hline Air rate & -3.18 \\
\hline Wash water & 0.26 \\
\hline
\end{tabular}

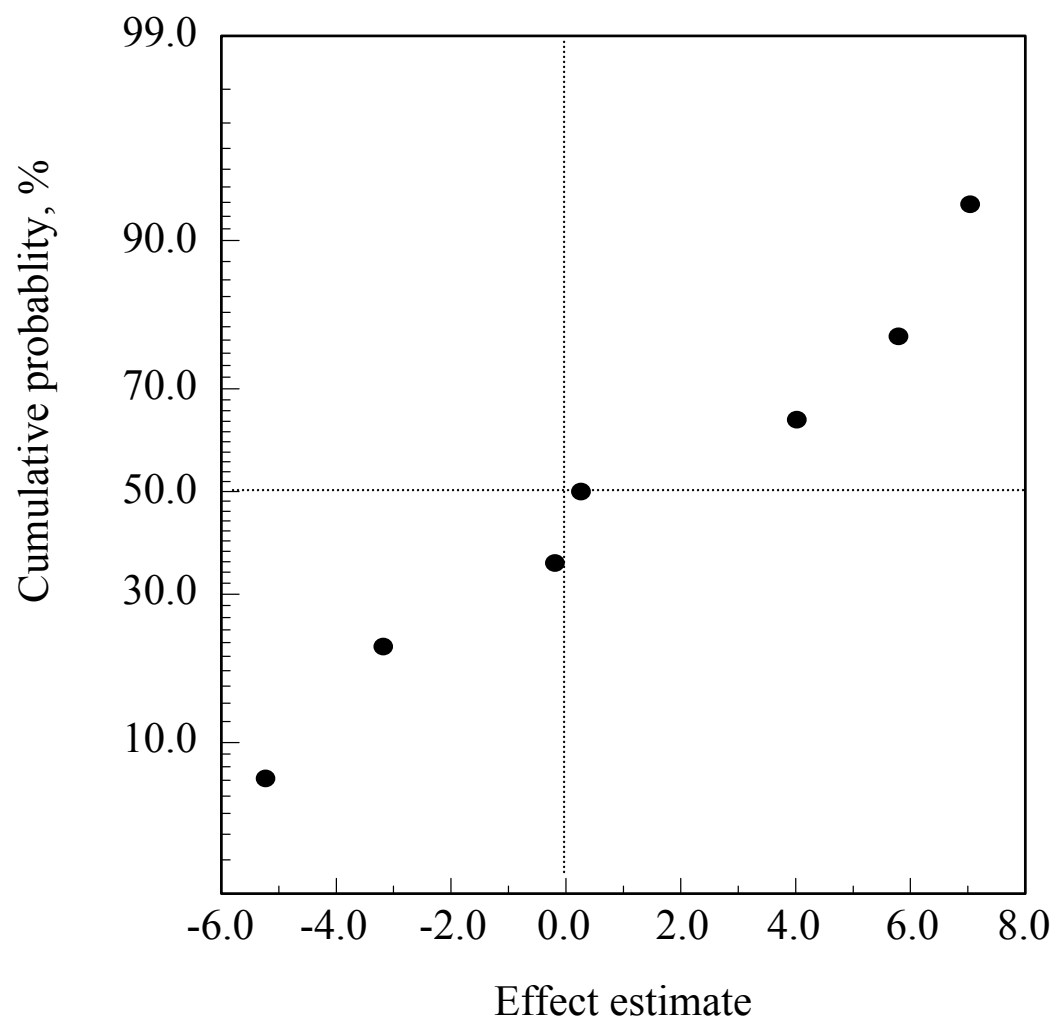

Figure 4-13 Normal Probability Plot of Effect Estimates for Factorial Design I, Step-one Experiment 
(4) Main effect of $\mathrm{pH}$ : The higher level of $\mathrm{pH}$ value yields an effect of SIp value 7.04 higher than the low level of $\mathrm{pH}$ value. This effect is the largest relative to others. It means $\mathrm{pH}$ should be further increased.

(5) Main effect of collector dosage: $1.3 \mathrm{~kg} / \mathrm{t} \mathrm{PA-31} \mathrm{dosage} \mathrm{yields} \mathrm{an} \mathrm{effect} \mathrm{of} \mathrm{SIp} \mathrm{value}$ 5.79 higher than $1.0 \mathrm{~kg} / \mathrm{t}$ PA-31. It indicates that more collector is needed for the next set of experiment.

(6) Main effect of feed solid: $25 \%$ feed solid yields an effect of SIp value similar to that by $20 \%$ solid. There is no significant effect when the feed solid is changed from $25 \%$ to $20 \%$.

(7) Main effect of wash water: $252 \mathrm{~mL} / \mathrm{min}$ wash water yields an effect of SIp value close to that by $189 \mathrm{~mL} / \mathrm{min}$. There is no much difference when wash water is changed from 189 to $252 \mathrm{~mL} / \mathrm{min}$.

Based on the factorial design I, step-one experiment, step-two experiment was conducted by selecting the factors having significant effects. Those factors included $\mathrm{pH}$, collector dosage, feed rate, interface (froth height) and air flow rate. The levels of the factors and the experiment design for factorial design I, step-two experiment are listed in Tables 410 and 4-11, respectively. The results of factorial design I, step-two experiment are given in Table 4-12. The main effect estimates were made using same procedure described above and they are presented in Table 4-13. The data in Table 4-13 show that the main effects are much smaller than those of step-one experiment. The $\mathrm{pH}$ should be at low level, between 5.0 and 5.5. Air flow rate should be run at high level, $4.7 \mathrm{~L} / \mathrm{min}$. Other factors can be considered having no significant effect at this stage. Thus, the best operation conditions at this stage are 
$\mathrm{pH} 5.5, \mathrm{PA}-311.5 \mathrm{~kg} / \mathrm{t}$, air flow rate $4.7 \mathrm{~L} / \mathrm{min}$, froth height $40 \mathrm{~cm}$, feed rate $350 \mathrm{~mL} / \mathrm{min}$, wash water $189 \mathrm{~mL} / \mathrm{min}$ and solid concentration $25 \%$.

After the first set of experiment, another set of tests were conducted with the standard fractional factorial design which is output from JUMP V.4 statistics software. In this set of experiment, five factors, flotation $\mathrm{pH}$, collector dosage, air flow rate, froth height (interface) and feed rate were considered. Test results and the main effect estimates of five factors based on SIp are given in Table 4-14 and Table 4-15, respectively. It should be pointed out that the second set of experiment was run on a newly installed packed column with the same dimension of the one for first set of experiment.

The test results of the second set of experiment design indicated that the optimum performance could be achieved at high collector dosage, $1.6 \mathrm{~kg} / \mathrm{t}$, and low $\mathrm{pH}, 5.0$, and all other conditions at low level.

\subsubsection{Silica Flotation of Dolomitic Phosphate Flotation Sink}

Dolomitic phosphate flotation sink at optimum operation conditions was collected and sized at $38 \mu \mathrm{m}$ (400 mesh). The plus $38 \mu \mathrm{m}$ was subject to amine flotation using the procedures and reagent described in Section 3.2.3. The material balance of dolomitic phosphate flotation and amine flotation is presented in Table 4-16. Table 4-16 shows that the final composite phosphate concentrate contained $30.22 \% \mathrm{P}_{2} \mathrm{O}_{5}$ and $0.96 \% \mathrm{MgO}$ at the overall $\mathrm{P}_{2} \mathrm{O}_{5}$ recovery of $91.62 \%$. 


\subsubsection{Comparison of Test Results with Denver D-12 Cell Data}

Figure 4-14 plots the results of dolomitic phosphate flotation using both Denver 1.2 liter stirrer-tank cell flotation and 2-in ID packed column flotation to show the relationship between the $\mathrm{MgO}$ and $\mathrm{P}_{2} \mathrm{O}_{5}$ grade as well as the overall $\mathrm{P}_{2} \mathrm{O}_{5}$ recovery. Figure 4-14 shows that, with the decrease of $\mathrm{MgO}$ grade in the sink product of dolomitic phosphate flotation, $\mathrm{P}_{2} \mathrm{O}_{5}$ grade increases and $\mathrm{P}_{2} \mathrm{O}_{5}$ recovery decreases. The trend is similar to the results from Denver cell flotation. At the $\mathrm{MgO}$ grade range of 0.85 to $1.1 \%$, the $\mathrm{P}_{2} \mathrm{O}_{5}$ grades are close to each other, but the $\mathrm{P}_{2} \mathrm{O}_{5}$ recovery of packed column flotation is lower than that of Denver cell flotation. In this study, the performance of packed column flotation is not up to that achieved by Denver cell. However, it is the first time to use packed column flotation for processing dolomitic phosphate ores. These results indicate that the further factorial design can be formulated to screen the operation conditions to approach the optimum operation conditions to process dolomitic phosphate ores using packed flotation column. 
Table 4-10 Levels of the Factors Used in Factorial Design I, Step-two Experiment

\begin{tabular}{|l|c|c|}
\hline \multicolumn{1}{|c|}{ Factors } & Low level & High level \\
\hline $\mathrm{A}=\mathrm{pH}$ & 5.5 & 6.0 \\
\hline $\mathrm{B}=$ Collector $(\mathrm{kg} / \mathrm{t})$ & 1.5 & 1.8 \\
\hline $\mathrm{C}=$ Air flow rate $(\mathrm{L} / \mathrm{min})$ & 3.8 & 4.7 \\
\hline $\mathrm{D}=$ Interface $(\mathrm{cm})$ & 30 & 40 \\
\hline $\mathrm{E}=$ Feed rate $(\mathrm{mL} / \mathrm{min})$ & 350 & 400 \\
\hline
\end{tabular}

Table 4-11 Experiment Design for Factorial Design I, Step-two Experiment

\begin{tabular}{|c|c|c|c|c|c|}
\hline Run & A & B & C & D & E \\
\hline 1 & - & - & - & - & - \\
\hline 2 & - & + & + & + & - \\
\hline 3 & - & - & + & + & + \\
\hline 4 & + & - & - & + & + \\
\hline 5 & + & + & - & - & + \\
\hline 6 & + & + & + & - & - \\
\hline
\end{tabular}


Table 4-12 Dolomitic Phosphate Flotation Results Using Packed Flotation Column Based on Factorial Design I, Step-two Experiment

\begin{tabular}{|c|c|c|c|c|c|c|c|}
\hline \multirow{2}{*}{ No. } & \multirow{2}{*}{ Product } & \multirow{2}{*}{ Wt. $\%$} & \multicolumn{2}{|c|}{ Grade, $\%$} & \multicolumn{2}{|c|}{ Recovery, \% } & \multirow{2}{*}{ SIp } \\
\hline & & & $\mathrm{P}_{2} \mathrm{O}_{5}$ & $\mathrm{MgO}$ & $\mathrm{P}_{2} \mathrm{O}_{5}$ & $\mathrm{MgO}$ & \\
\hline \multirow{3}{*}{1} & Float & 11.73 & 13.63 & 10.77 & 6.00 & 59.59 & \multirow{3}{*}{62.96} \\
\hline & Sink & 88.27 & 28.38 & 0.97 & 94.00 & 40.41 & \\
\hline & Head & 100.00 & 26.65 & 2.12 & 100.00 & 100.00 & \\
\hline \multirow{3}{*}{2} & Float & 13.07 & 15.40 & 9.82 & 7.57 & 62.30 & \multirow{3}{*}{62.99} \\
\hline & Sink & 86.93 & 28.28 & 0.89 & 92.43 & 37.70 & \\
\hline & Head & 100.00 & 26.60 & 2.06 & 100.00 & 100.00 & \\
\hline \multirow{3}{*}{3} & Float & 12.31 & 13.92 & 10.49 & 6.43 & 62.69 & \multirow{3}{*}{64.44} \\
\hline & Sink & 87.69 & 28.45 & 0.88 & 93.57 & 37.31 & \\
\hline & Head & 100.00 & 26.66 & 2.06 & 100.00 & 100.00 & \\
\hline \multirow{3}{*}{4} & Float & 13.86 & 15.64 & 8.62 & 8.12 & 56.09 & \multirow{3}{*}{58.99} \\
\hline & Sink & 86.14 & 28.48 & 1.09 & 91.88 & 43.91 & \\
\hline & Head & 100.00 & 26.70 & 2.13 & 100.00 & 100.00 & \\
\hline \multirow{3}{*}{5} & Float & 14.88 & 17.22 & 8.87 & 9.58 & 63.15 & \multirow{3}{*}{61.76} \\
\hline & Sink & 85.12 & 28.40 & 0.90 & 90.42 & 36.85 & \\
\hline & Head & 100.00 & 26.74 & 2.09 & 100.00 & 100.00 & \\
\hline \multirow{3}{*}{6} & Float & 15.53 & 17.46 & 8.16 & 10.17 & 61.52 & \multirow{3}{*}{60.21} \\
\hline & Sink & 84.47 & 28.35 & 0.94 & 89.83 & 38.48 & \\
\hline & Head & 100.00 & 26.66 & 2.06 & 100.00 & 100.00 & \\
\hline
\end{tabular}


Table 4-13 Main Effects of the Factors Using $\mathrm{SI}_{\mathrm{p}}$ as Response for Factorial Design I, Step-two Test

\begin{tabular}{|c|c|}
\hline Factors & Effect \\
\hline PH & -3.14 \\
\hline Collector & -0.48 \\
\hline Airflow rate & 1.31 \\
\hline Interface & 0.50 \\
\hline Feed rate & -0.32 \\
\hline
\end{tabular}


Table 4-14 Dolomitic Phosphate Flotation Results Using Packed Flotation Column Based on Factorial Design II

\begin{tabular}{|c|c|c|c|c|c|c|c|}
\hline \multirow{2}{*}{$\begin{array}{l}\text { Test } \\
\text { No. }\end{array}$} & \multirow{2}{*}{ Product } & \multirow{2}{*}{ Wt.\% } & \multicolumn{2}{|c|}{ Grade, $\%$} & \multicolumn{2}{|c|}{ Recovery, \% } & \multirow{2}{*}{$\begin{array}{c}\text { Response } \\
\text { SIp }\end{array}$} \\
\hline & & & $\mathrm{P}_{2} \mathrm{O}_{5}$ & $\mathrm{MgO}$ & $\mathrm{P}_{2} \mathrm{O}_{5}$ & $\mathrm{MgO}$ & \\
\hline \multirow{3}{*}{1} & Float & 9.04 & 13.65 & 10.68 & 4.64 & 45.12 & \multirow{3}{*}{54.69} \\
\hline & Sink & 90.96 & 27.90 & 1.29 & 95.36 & 54.88 & \\
\hline & Head & 100.00 & 26.61 & 2.14 & 100.00 & 100.00 & \\
\hline \multirow{3}{*}{2} & Float & 11.02 & 14.91 & 9.81 & 6.18 & 49.59 & \multirow{3}{*}{56.31} \\
\hline & Sink & 88.98 & 28.03 & 1.24 & 93.82 & 50.41 & \\
\hline & Head & 100.00 & 26.58 & 2.18 & 100.00 & 100.00 & \\
\hline \multirow{3}{*}{3} & Float & 8.46 & 13.24 & 11.13 & 4.21 & 44.00 & \multirow{3}{*}{54.30} \\
\hline & Sink & 91.56 & 27.85 & 1.31 & 95.79 & 56.00 & \\
\hline & Head & 100.00 & 26.61 & 2.14 & 100.00 & 100.00 & \\
\hline \multirow{3}{*}{4} & Float & 12.73 & 16.53 & 8.87 & 7.91 & 54.29 & \multirow{3}{*}{57.70} \\
\hline & Sink & 87.27 & 28.07 & 1.09 & 92.09 & 45.71 & \\
\hline & Head & 100.00 & 26.60 & 2.08 & 100.00 & 100.00 & \\
\hline \multirow{3}{*}{5} & Float & 10.93 & 14.66 & 9.92 & 6.03 & 49.74 & \multirow{3}{*}{56.56} \\
\hline & Sink & 89.07 & 28.04 & 1.23 & 93.97 & 50.26 & \\
\hline & Head & 100.00 & 26.58 & 2.18 & 100.00 & 100.00 & \\
\hline \multirow{3}{*}{6} & Float & 12.03 & 15.64 & 9.75 & 7.05 & 55.59 & \multirow{3}{*}{59.46} \\
\hline & Sink & 87.97 & 28.21 & 1.07 & 92.95 & 44.41 & \\
\hline & Head & 100.00 & 26.70 & 2.11 & 100.00 & 100.00 & \\
\hline \multirow{3}{*}{7} & Float & 11.94 & 16.32 & 8.76 & 7.33 & 50.29 & \multirow{3}{*}{55.64} \\
\hline & Sink & 88.06 & 27.99 & 1.17 & 92.67 & 49.71 & \\
\hline & Head & 100.00 & 26.60 & 2.08 & 100.00 & 100.00 & \\
\hline \multirow{3}{*}{8} & Float & 12.77 & 15.82 & 9.51 & 7.57 & 57.56 & \multirow{3}{*}{60.26} \\
\hline & Sink & 87.23 & 28.29 & 1.03 & 92.43 & 42.44 & \\
\hline & Head & 100.00 & 26.58 & 2.18 & 100.00 & 100.00 & \\
\hline
\end{tabular}


Table 4-15 Main Effects of the Factors Using $\mathrm{SI}_{\mathrm{p}}$ as Response for Factorial Design II

\begin{tabular}{|c|c|}
\hline Factors & Effect \\
\hline $\mathrm{PH}$ & -0.63 \\
\hline Collector & 2.80 \\
\hline Airflow rate & -0.68 \\
\hline Interface & -0.48 \\
\hline Feed rate & -0.75 \\
\hline
\end{tabular}

Table 4-16 Material Balance of Dolomitic Phosphate Flotation and Silica Flotation

\begin{tabular}{|c|c|c|c|c|c|c|c|}
\hline \multirow{2}{*}{ Product } & \multirow{2}{*}{$\begin{array}{c}\text { Wt. } \\
\%\end{array}$} & \multicolumn{3}{|c|}{ Grade, \% } & \multicolumn{3}{c|}{ Recovery, \% } \\
\cline { 3 - 8 } & $\mathrm{P}_{2} \mathrm{O}_{5}$ & $\mathrm{MgO}$ & $\mathrm{SiO}_{2}$ & $\mathrm{P}_{2} \mathrm{O}_{5}$ & $\mathrm{MgO}$ & $\mathrm{SiO}_{2}$ \\
\hline Dolomite float & 12.45 & 14.95 & 10.46 & 5.21 & 7.01 & 62.39 & 6.13 \\
\hline Silica float & 7.10 & 5.11 & 0.19 & 84.22 & 1.37 & 0.65 & 54.68 \\
\hline$-38 \mu \mathrm{m}(-400$ mesh) & 27.15 & 28.41 & 1.33 & 8.67 & 29.07 & 17.30 & 22.23 \\
\hline Silica sink & 53.30 & 31.14 & 0.77 & 3.01 & 62.55 & 19.66 & 15.15 \\
\hline Head & 100.00 & 26.53 & 2.09 & 10.59 & 100.00 & 100.00 & 100.00 \\
\hline Composite conc. $*$ & 80.45 & 30.22 & 0.96 & 4.92 & 91.62 & 36.96 & 37.39 \\
\hline
\end{tabular}

* Composite concentrate is formed by combining the sink product of fatty acid amine flotation with minus $-38 \mu \mathrm{m}(-400 \mathrm{mesh})$ of dolomite flotation. 


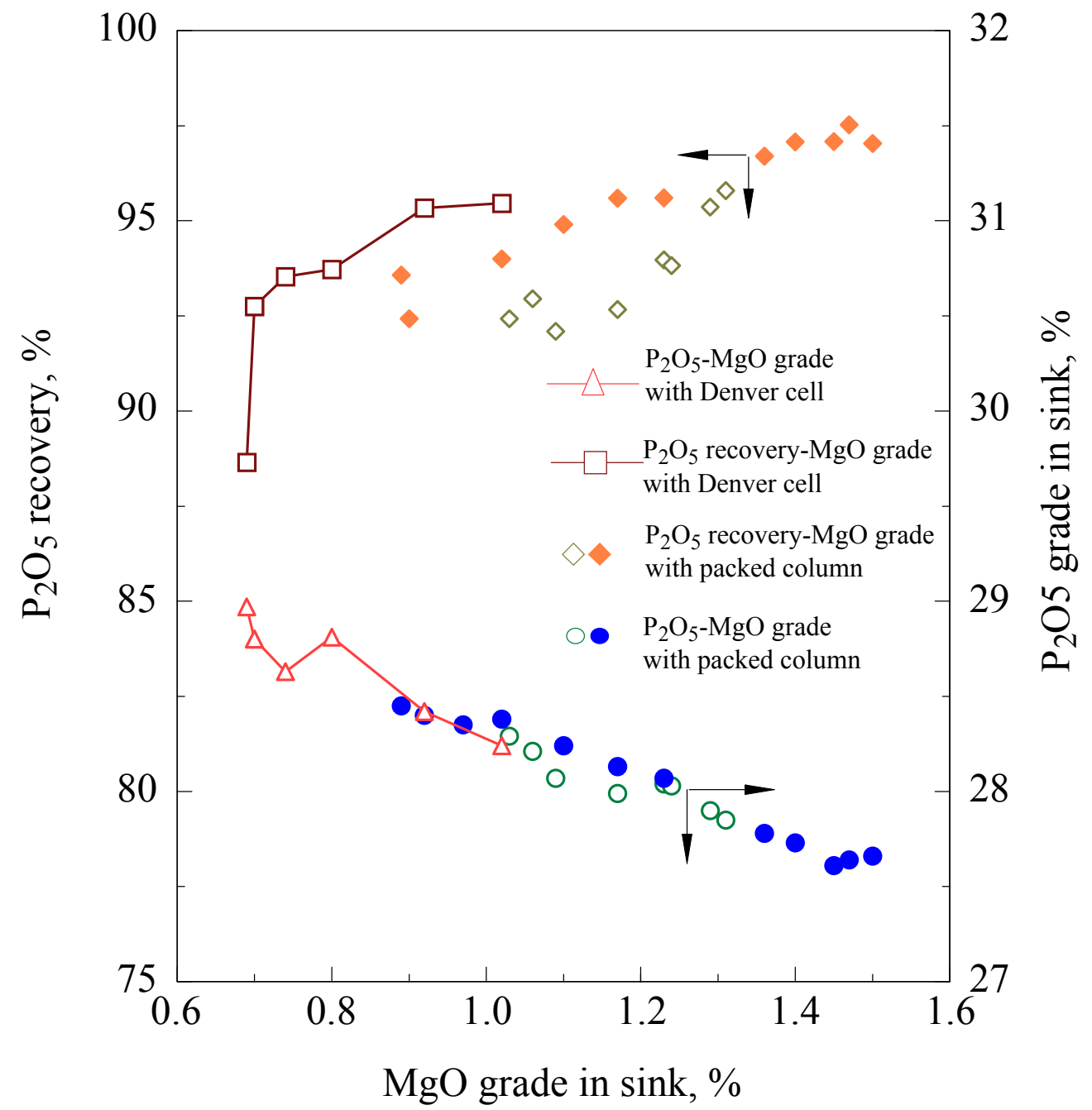

Figure 4-14 Relationship between $\mathrm{MgO}$ and $\mathrm{P}_{2} \mathrm{O}_{5}$ Grades and $\mathrm{P}_{2} \mathrm{O}_{5}$ Recovery in the Sink Product of Dolomitic Phosphate Flotation Using Denver Cell and Packed Column 


\section{CHAPTER 5 CONCLUSONS}

The laboratory flotation study has been conducted on typical Florida dolomitic phosphate pebble sample. The work includes mineralogical study on the sample, grinding time for mineral liberation, frothability evaluation of collectors, dolomitic phosphate flotation rate by employing laboratory Denver D-12 stirrer-tank cell and packed flotation column. The conclusions derived from this study can be made as follows:

(1) The mineralogical study results show that the sample is a typical dolomitic phosphate pebble sample (DPP) containing $74 \%$ carbonated fluorapatite, $10 \%$ dolomite, $8 \%$ to $10 \%$ quartz and some other minerals. The theoretical $\mathrm{P}_{2} \mathrm{O}_{5}$ grade of the pure apatite mineral in this sample is $36 \%$. There is $0.45 \%$ to $0.50 \% \mathrm{MgO}$ existing in the lattice of apatite mineral which can not be removed through physical procedures. Microscopic observation indicates that the dolomite mineral is finely disseminated with phosphate minerals. The DPP sample needs to be ground to minus $150 \mu \mathrm{m}(-100 \mathrm{mesh})$ for satisfactory liberation of dolomite from phosphate.

(2) Frothability measurements show that fatty acid PA-31 has stronger frothability than fatty acid FA-12. The froth height increases with aeration rate and reagent concentration, and the froth generated has 2-3 $\mathrm{mm}$ diameter bubble size resemble to the froth of polyglycol ether frother. After reaching a certain concentration, the bubble size of froth becomes smaller, voluminous, flowing over the lip of the froth column meter, and extremely persistent.

(3) The results of dolomitic phosphate flotation rate study show that the newly developed dolomite collector PA-31 has higher selectivity than collector FA-12 in separating 
dolomite from phosphate at $\mathrm{pH}$ 5.5. The optimum dosage of the collectors PA-31 and FA-12 is $1.0 \mathrm{~kg} / \mathrm{t}$ of feed.

(4) To improve the effectiveness of fatty acid amine flotation for rejecting silica, the sink product of dolomite flotation is sized at $38 \mu \mathrm{m}$ (400 mesh). The plus $38 \mu \mathrm{m}$ fraction is subject to silica flotation using fatty acid amine AR-1051 as a collector. The minus $38 \mu \mathrm{m}$ fraction is combined with the sink product of silica flotation to form the composite phosphate concentrate.

(5) Double reverse flotation process, namely dolomite flotation and silica flotation, is developed and used to reject both dolomite and silica from minus $150 \mu \mathrm{m}$ DPP sample to produce an acceptable phosphate concentrate for fertilizer industry. Using Denver 1.2 liter stirrer-tank cell, a final composite phosphate concentrate containing $31.66 \% \mathrm{P}_{2} \mathrm{O}_{5}$ and $0.79 \% \mathrm{MgO}$ is obtained at the overall $\mathrm{P}_{2} \mathrm{O}_{5}$ recovery of $92.16 \%$ from the feed of $26.68 \% \mathrm{P}_{2} \mathrm{O}_{5}$ and $2.14 \% \mathrm{MgO}$.

(6) The results of packed column flotation show that major operation parameters are $\mathrm{pH}$, collector dosage, feed solid concentration, froth height and air flow rate, wash water and interface (froth height).

(7) Packed flotation column is used to process minus $150 \mu \mathrm{m}$ DPP in dolomite flotation. Denver stirrer-tank flotation cell is used to process plus $38 \mu \mathrm{m}$ size fraction of the sink product obtained from dolomite flotation in silica flotation. By combining the sink product of silica flotation and minus $38 \mu \mathrm{m}$ size fraction of dolomite flotation sink, a composite phosphate concentrate containing $30.22 \% \mathrm{P}_{2} \mathrm{O}_{5}$ and $0.96 \% \mathrm{MgO}$ is achieved at the overall $\mathrm{P}_{2} \mathrm{O}_{5}$ recovery of $91.62 \%$. 


\section{RECOMMENDATIONS}

In spite that a composite phosphate concentrate containing $30.22 \% \mathrm{P}_{2} \mathrm{O}_{5}$ and $0.93 \%$ $\mathrm{MgO}$ can be achieved at the overall $\mathrm{P}_{2} \mathrm{O}_{5}$ recovery of $91 \%$ in this study using packed flotation column for dolomitic phosphate flotation, but the results are not up to that achieved by the flotation conducted in a Denver 1.2 liter stirrer-tank cell. Further work is recommended as followings:

(1) In this study, the bubbles are generated by snarling and passing between packing plates, and packing plates and wall. The large bubbles deform or change size in order to pass through the winding narrow paths. When the air flow is high, such as 5.6 L/min, the size of the bubbles generated are very big and the bubbles pass through the passage and reach the slurry-froth interface very fast. While at low air flow rate, such as less than $2.0 \mathrm{~L} / \mathrm{min}$, the bubbles becomes smaller compared with ones at high air flow rate, but also fewer. Too big or too few bubbles will reduce the collision of the particles and bubbles. More investigations are needed to understand the mechanism of bubble generation in the packed flotation column, the effects of bubble vibration on the hydrophobic particles adhered on the bubbles surface for selective flotation.

(2) The bubble size is one of the important factors in mineral flotation, particularly for fine particle flotation in open column. The bubble generation determines the momentum of the bubbles for particle collision. Generally, fine particle flotation needs small bubbles to increase solids carrying capacity in an open column. The open column might be applicable to dolomite flotation. 
(3) The slurry is conditioned in a sump with a stirrer continuously throughout the experiment. A conditioning tubing loop with a static mixer is also installed and used in packed column flotation tests. But it seems that there is not enough collision energy for the attachment of the particles to bubbles. The study of addition of collision energy of particles and bubbles prior to or in the packed column need to be further studied.

(4) One of the major advantages in column flotation is that the froth product can be recleaned by counter current wash water over the froth layer from the top of the column. The dolomite particles present relatively small amount (about 10\%) in DPP sample. The low floated dolomite particles can not sustain a deep froth layer as expected in packed flotation column. More studies should be done to explore the effect of wash water on the thin and lean froth layer of dolomite flotation in packed flotation column.

(5) PA-31 is a newly developed fatty acid type collector, which shows a high selectivity for dolomite rejection in dolomitic phosphate flotation. Fatty acid collector, FA-12 from ARR-MAZ Products, also shows relatively high selectivity in dolomite flotation. More fundamental studies are needed to identify the main components of the collector PA-31, and substitute collector FA-12, to better understand the function of these collectors on selective adsorption on dolomite minerals. 


\section{REFERENCES}

Abdel-Khalek, N. A., 2001, "Separation of Dolomite from Phosphate Minerals by Flotation with a New Amphoteric Surfactant as Collector", Mineral Processing and Extractive Metallurgy, v110, pp. C89-C93.

Abdel-Khalek, N. A., Hassan, F. and Arafa, M. A., 2000, "Separation of Valuable Fine Phosphate Particles from Their Slimes by Column Flotation", Separation Science and Technology, v35, n7, pp. 1077-1086.

Abu-Elshah, S. I., 1991, "A New Technique for the beneficiation of Low Grade Carbonate Rich Phosphate Rocks by Digestion with Dilute Acetic Acid Solutions: Pilot Plant Testing Results", Minerals Engineering, Vol. 4 (5/6), pp. 573-586.

Ahmed, N and Jameson, G. J., 1985, "The Effect of Bubble Size on the Rate of Flotation of Fine Particles”, Int. J. Mineral Processing, Vol. 15 pp. 195-215.

Al-Fariss, T. F., 1993, "Beneficiation of a Carbonate Rich Saudi Phosphate Rocks", Engineering Foundation Conference. Beneficiation of Phosphates: Theory and Practice", SME, Dec. 5-10, Palm Coast, FL.

Ananthapadmanabhan, K. P., and Somasundaran, P., 1985, "Surface Precipitation of Inorganic and Surfactants and its Role in Adsorption and Flotation", Colloids Surfaces, Vol. 13, pp. 151-167.

Association of Fertilizer and Phosphate Chemists (AFPC), 1991, "Analytical Methods for Phosphate Industry", $7^{\text {th }}$ edition.

Atalay, V., 1985, "Beneficiation of Low Grade Tasit Phosphate Ore from Turkey", In Proceedings, World Congress on Non-Metallic Minerals, Belgrade, Yugoslavia, April, pp. 389-396.

Baumann, A. N., and Snow, R. E., 1980, "Processing Techniques for Separating MgO Impurities from Phosphate Products", In Proceedings, 2nd International Congr. Phosphorus Compounds, April, pp. 269-280.

Belyakov, V. A., 1981, "Effect of Conditions for the Acid Leaching of Carbonates from Kingisepp Phosphrites on the Particle Size Distribution and Flotation Properties of Solid Phases", Tekhnol, Mineral'n Udobrenii, L (Russ), pp. 3-9.

Clerici, C., 1984, "Flotation of a Phosphate Rock with Carbonate-Quartz Gangue", Reagents in the Mineral Industry, Jones, M.J. and Oblatt, R., eds., IMM, London, pp. 221-225. 
Davis, B. E., Liewellyn, T. O., and Smith, C. W., 1984, "Continuous Beneficiation of Dolomitic Phosphate Rocks", RI 8903, USBM.

El-Shall, H., Zhang, P. and Snow, R., 1996, "Comparative Analysis of Dolomite/Francolite Flotation Techniques”, Minerals and Metallurgical Processing, pp. 135-140.

El-Shall, H. and Abdel-Khalek, N. A., 2000, "Collector-Frother Interaction in Column Flotation of Florida Phosphate", Int'1 J. of Mineral Processing, v58, n1, pp.187-199.

El-Shall, H., Cheng, Y. H., Abdel-Khalek, N. A. and Gupta, S., 1998, "A Parametric Study of Column Flotation of Florida Phosphates", Engineering Foundation Conference. Beneficiation of Phosphates: "Advance in Research and Practice", SME, Dec. 5-10, Palm Coast, FL, pp. 75-86.

Espinosa-Gomez, R., Finch, J. A., Yianatos, J. B. and Dobby, G. S., 1988, "Flotation Column Carrying Capacity: Particle Size and Density Effects", Mineral Engineering, Vol. 1, No. 1, pp. 77-79.

Finch, J. A. and Dobby, G. S., 1990, “Column Flotation”, $1^{\text {st }}$ ed., Pergmon Press, New York, NY, pp. 25-26, 75-102.

Fu, E., and Somasundaran, P., 1986, "Alizarin Red S as a Flotation Modifying Agent in Calcite-Apatite Systems", Int. J. of Mineral Processing, 18, pp. 287-296.

Fuerstenau, M. C., 1968, "The Influence of Sodium Silicate in Non-Metallic Flotation Systems", Trans AIME, Vol. 241, pp. 319-323.

Gao, Z. Z., Zheng, S. B. and Gu, Z. X., 2001, "Review of Beneficiation Technology for Florida High-MgO Pebble", Engineering Foundation Conference. Beneficiation of Phosphates III, SME, Dec. 2-7, St. Pete Beach, FL.

Gao, Z. Z. and Gu, Z. X., 1998, "Plant Practice of Phosphate Beneficiation in China", Engineering Foundation Conference. Beneficiation of Phosphates: "Advance in Research and Practice", SME, Dec. 5-10, Palm Coast, FL.

Good, P. C., 1976, "Beneficiation of Unweathered Indian Calcareous Phosphate Rock by Calcination and Hydration", U. S. Government Printing Office, 1976-603-755/129, pp. 1-17.

Gruber, G. A., Raulerson J. D., and Farias, R. P., 1987, "Adapting Technoloey to Beneficiate a Low-Grade Phosphorite Ore", Minerals and Metallurgical Processing, Feb., pp. 14-18.

Gu, Z. X, Gao, Z. Z. and Zheng S. B., 1998, "Beneficiation of Florida Dolomitic Phosphate Pebble with a Fine Particle Flotation Process", Engineering Foundation Conference. Beneficiation of Phosphates: "Advance in Research and Practice", SME, Dec. 5-10, Palm Coast, FL, pp. 155-162. 
Hanna, J., and Anazia, I., 1990, "Selective Flotation of Dolomitic Limestone Impurities from Florida Phosphates", FIPR Publication No. 02-066-089.

Houot, R., and Polgaire, J. L., 1980, "Inverse Flotation Beneficiation of Phosphate Ores", In Proceedings, 2nd International Congress on Phosphorus Compounds, Boston, April, pp. 231246.

Houot, R., 1982 "Beneficiation of Phosphatic Ores through Flotation: Review of Industrial Applications and Potential Developments," International Journal of Mineral Processing, No.9, pp.353.

Hsieh, S. S., and Lehr, J. R., 1985, "Beneficiation of Dolomitic Idaho Phosphate Rock by the TVA Diphosphonic Depressant Process", Mineral and Metallurgical processing, Feb., pp. 1013.

Huang, W. G. and Zhang G. L., 1993, "Beneficiating Baokang Phosphate ore with Heavy Medium Separation Process," Chemical Mines Technology, No.2, pp.24.

Hutwelker, J. F., Schlesinger, L. M., Garska, M. J. and Tanner, J. T., 1993, "High Throughput, High Solids Flotation of $20 \times 200$ mesh North Carolina Phosphate in a Short Column Cell", Engineering Foundation Conference, Beneficiation of Phosphates: Theory and Practice, Dec. 5-10, Palm Coast, FL., pp. 371-382.

Inoue Junichi, 1996, Assessment of Packed Column Flotation Efficiency for Coal Cleaning", M. S. thesis, Wets Virginia University.

Ityokumbul, M.T. and Trubelja, M. P. 1998, "Carrying Capacity in a Pilot Flotation Column, Minerals and Metallurgical Processing, v15, pp. 41-46..

Kromf, R. A., Trushchenko, N. N. and Belyakov, V. A., 1979, "Removal of Magnesium from Kingisepp Flotation Concentrate with Sulfuric Acid", Tekhnol, Mineral'n Udobrenii, (Russian), pp. 14-19.

Laird, D. H., and Ng, D., 1992, "Magnesium Separation from Dolomitic Phosphate by Acid Leaching", Final Report, FIPR Project \#91-01-093.

Lawendy, T. A. B. and Van Kauwenbergh S. J., 1993, "Flotation of Dolomitic and Calcareous Phosphate Ores", Engineering Foundation Conference, Beneficiation of Phosphates: Theory and Practice, Dec. 5-10, Palm Coast, FL., pp.29-44.

Lawver, L. E., and Snow, R. E., 1980, "Method of Beneficiating Phosphate Ores", U. S. Patent 4,189,103, Feb. 19. 
Lehr, J.R., and Hsieh, S.S., 1981, "Beneficiation of High Carbonate Phosphate Ores", U. S. Patent 4,287,053.

Llewellyn, T. D., "Beneficiation of High-Magnesium Phosphate from Southern Florida, 1982, RI 8609, USBM.

Lu Shouci and Sun Keji, 1998, "Development of Phosphate Flotation Reagents in China", Engineering Foundation Conference. Beneficiation of Phosphates: "Advance in Research and Practice", SME, Dec. 5-10, Palm Coast, FL, pp. 21-26.

Mahlanggu, T., Nyamhunga, M., Simbi, D. J. and Fernandes, T. R. C., 1998, "Column Flotation of Dorowa Rock Phosphate Slimes", Engineering Foundation Conference. Beneficiation of Phosphates: "Advance in Research and Practice", SME, Dec. 5-10, Palm Coast, FL, pp. 95-102.

Montgamery, Douglas C., 1999, "Design and Analysis of Experiments", Fifth Edition, John Wiley \& Sons, Inc. pp. 303-349.

Moudgil, B. M. Moudgil and Somasundaran, P., 1986, "Advances in Phosphate Beneficiation," Advances in Mineral Processing, Arbiter Symposium, SME, pp.426.

Moudgil, B. M., et al., 1986, "Separation of Dolomite From the South Florida Phosphate Rock", FIPR Publication No. 02-023-051.

Peng, F. F., and Xia, Y. K., 2002a, "Evaluation of Solvents for the Frothers of CopperMolybdenite Sulfide Mineral Flotation”, Preprint 02-196, 2002 SME Annual Meeting, Phoenix, AZ, Feb. 25-27.

Peng, F. F., and Xia, Y. K., 2002b, "Stability of Foam and Frother Evaluation Methodology", Preprint 02-184, 2002 SME Annual Meeting, Phoenix, AZ, Feb. 25-27.

Prasad, M., Majumder, A. K. and Rao T. C., 2000, "Reverse Flotation of Sedimentary Calcareous/Dolomitic Rock Phosphate Ore-an Overview", Minerals \& Metallurgical Processing, v17, n1, pp.49-55.

Rao, D.V., 1985, "Flotation of Calcareous Mussorie Phosphate Ore", Int. J. Mineral Processing, Vol. 14, pp. 57-66.

Rao, D.V., 1979, "Flotation of Low Grade Phosphate Ore", Int. Symp. on Resources Eng. and Tech., Jan. 8-11, pp. 1-7.

Rao, K. H., 1989, "Flotation of Phosphatic Material Containing Carbonatic Gangue Using Sodium Oleate as Collector and Sodium Silicate as Modifier", Int. J of Mineral Processing,Vol. 26, pp. 123-140. 
Rao, H. K., 1988, "Mechanism of Oleate Interaction on Salt-type Minerals, I. Adsorption and Electrokinetic Studies of Calcite in the Presence of Sodium Oleate and Sodium Metasilicate", Colloids Surfaces, Vol. 34, pp. 227-239.

Ratobylskaya, L. D., 1975, "La Valorisation de Phosphates Mineraux Pauvres a Gangue Carbonate", Preprints 11, Congres Int. de Valorisation des Minerais Seminaire Sur, pp. 1739.

Rule, A. R., 1985, "Beneficiation of Complex Phosphate Ores Containing Carbonate and Silica Gangue", In Proceedings, XVth IMPC, Vol. 3, pp. 380-389.

Rule, A. R., et al., 1970, "Removal of Magnesium Impurities from Phosphate Rock Concentrates", USBM RI 7362.

Rule, A. R., 1982, "Application of Carbonate-Silica Flotation Techniques to Western Phosphate Materials", RI 8728, USBM.

Saint-Guilhem, R., 1975, "La Valorisation des Phosphates Mineraux Pauvres a Gangue Carnobatee", Reprients 11, Congres International de Valorisation des Minerais Seminaire sur, pp. 3-15.

Smani, S., Cases, J. M., and Blazy, P., 1975, "Beneficiation of Sedimentary Moroccan Phosphate Ore, Part 3. Selective Flotation and Recovery", Trans. SME-AIME, Vol. 258, pp. 176-180.

Soto, H., et al., 1986, "Selective Flotation of Phosphates from Dolomite Using Cationic Collectors," Int'1 J. of Mineral Processing, No.16, p.3.

Valoven, V. I., et al., 1979, "Study of the Extraction of Magnesium Depleted Kovodor Apatite", Khim. Prom-st, Ser: Fosfornaya Prom-st, Vol. 3, pp. 14-17.

Wiegel, R. L., 1998, "Phosphate Rock Beneficiation Practice in Florida", Engineering Foundation Conference. Beneficiation of Phosphates: "Advance in Research and Practice", SME, Dec. 5-10, Palm Coast, Florida

Wu L. T., 1985, "Studies on Removal of Magnesium Impurities from Carbonated Phosphate Rocks with Reverse Flotation Process," In Proceedings of the First Symposium of Phosphate Beneficiation in China.

Wu, L., and Forsling, W., 1993, "Surface Complexation of Calcium Minerals in Aqueous Solution - 2. The Complexation of Alizarin Red S at Fluorapatite-Water Interface", 1993, Engineering Foundation Conference, Beneficiation of Phosphates: Theory and Practice, Dec 5-10, Palm Coast, Florida. 
Xiao, L., and Somasundaran, P., 1989, "Interactions Between Oleate Collector and Alizarin Modifier in Dolomite/Francolite Flotation System," Minerals and Metallurgical Processing, May, pp. 100-103.

Zhang, P., 1993, "Phosphate Beneficiation-Trends of 90's," "Beneficiation of Phosphate: Theory and Practice." Palm Coast, Florida.

Zeng M. Y., 1998, “ Recovery of Coal Fines Using Packed Column Flotation with Reagent Enhancement”, M. S. thesis, West Virginia University. 


\section{Appendix I}

Frothability Measurement Data for FA-12 and PA-31 Collectors 
Table I-1. Frothability Data for FA-12 Collector

\begin{tabular}{|c|c|c|c|c|c|c|}
\hline \multirow{2}{*}{$\begin{array}{c}\text { Air flow } \\
\text { rate } \\
(\mathrm{L} / \mathrm{min})\end{array}$} & \multicolumn{7}{|c|}{ Reagent dosages, g/L } \\
\cline { 2 - 7 } & Water & 0.26 & 0.41 & 0.49 & 0.53 & 0.60 \\
\hline 0.05 & 0.25 & 0.50 & 0.85 & 1.50 & 2.40 & 4.10 \\
\hline 0.13 & 0.50 & 1.00 & 1.35 & 3.30 & 4.20 & 7.10 \\
\hline 0.25 & 0.80 & 1.50 & 2.10 & 4.80 & 7.20 & 11.10 \\
\hline 0.32 & 1.25 & 2.00 & 2.85 & 5.50 & 7.70 & 13.10 \\
\hline 0.48 & 2.00 & 2.50 & 3.50 & 6.10 & 8.20 & 14.10 \\
\hline 0.60 & 2.25 & 3.00 & 4.00 & 6.30 & 8.80 & 14.70 \\
\hline
\end{tabular}

Table I-1. Frothability Data for PA-31 Collector

\begin{tabular}{|c|c|c|c|c|c|c|}
\hline \multirow{2}{*}{$\begin{array}{c}\text { Air flow } \\
\text { rate } \\
(\mathrm{L} / \mathrm{min})\end{array}$} & \multicolumn{7}{|c|}{ Reagent dosages, g/L } \\
\cline { 2 - 7 } & Water & 0.03 & 0.075 & 0.09 & 0.105 & 0.12 \\
\hline 0.05 & 0.25 & 0.30 & 0.50 & 1.20 & 1.50 & 4.40 \\
\hline 0.13 & 0.50 & 0.70 & 1.20 & 2.00 & 2.90 & 6.40 \\
\hline 0.25 & 0.80 & 1.20 & 1.90 & 3.00 & 4.50 & 8.40 \\
\hline 0.32 & 1.25 & 1.80 & 2.50 & 4.20 & 6.50 & 10.40 \\
\hline 0.48 & 2.00 & 2.50 & 3.20 & 5.20 & 7.50 & 12.40 \\
\hline 0.60 & 2.25 & 2.80 & 4.00 & 5.70 & 8.50 & 13.40 \\
\hline
\end{tabular}




\section{Appendix II}

Dolomite Flotation Rate Data Using Different Type of Collectors at Various Dosages 
Table II-1 Dolomite Flotation Rate Data Using 0.5 kg/t FA-12

\begin{tabular}{|c|c|c|c|c|c|c|c|c|c|c|}
\hline $\begin{array}{c}\text { Time } \\
(\mathrm{s})\end{array}$ & $\begin{array}{c}\mathrm{Wt} \\
(\mathrm{g})\end{array}$ & $\begin{array}{c}\mathrm{Wt} \\
(\%)\end{array}$ & $\begin{array}{c}\mathrm{MgO} \\
\text { Grade }(\%)\end{array}$ & $\begin{array}{c}\text { Cumulative } \\
\mathrm{MgO} \text { grade } \\
(\%)\end{array}$ & $\begin{array}{c}\mathrm{MgO} \\
\text { Recovery } \\
(\%)\end{array}$ & $\begin{array}{c}\text { Cumulative } \\
\mathrm{MgO} \\
\text { recovery } \\
(\%)\end{array}$ & $\begin{array}{c}\mathrm{P}_{2} \mathrm{O}_{5} \text { grade } \\
(\%)\end{array}$ & $\begin{array}{c}\text { Cumulative } \\
\mathrm{P}_{2} \mathrm{O}_{5} \text { grade } \\
(\%)\end{array}$ & $\begin{array}{c}\mathrm{P}_{2} \mathrm{O}_{5} \\
\text { recovery } \\
(\%)\end{array}$ & $\begin{array}{c}\text { Cumulative } \\
\mathrm{P}_{2} \mathrm{O}_{5} \\
\text { recovery } \\
(\%)\end{array}$ \\
\hline 15 & 6.6 & 2.26 & 11.84 & 11.84 & 12.43 & 12.43 & 12.15 & 12.15 & 1.03 & 1.03 \\
\hline 30 & 5.9 & 2.02 & 10.44 & 11.18 & 9.79 & 22.22 & 14.48 & 13.25 & 1.10 & 2.13 \\
\hline 60 & 9.4 & 3.21 & 8.76 & 10.14 & 13.09 & 35.31 & 16.95 & 14.84 & 2.05 & 4.18 \\
\hline 120 & 10 & 3.42 & 6.49 & 9.00 & 10.32 & 45.63 & 20.33 & 16.56 & 2.61 & 6.79 \\
\hline 180 & 8.9 & 3.04 & 4.95 & 8.11 & 7.01 & 52.64 & 23.01 & 17.97 & 2.63 & 9.43 \\
\hline 300 & 7.0 & 2.39 & 3.22 & 7.40 & 3.58 & 56.22 & 26.12 & 19.16 & 2.35 & 11.78 \\
\hline 350 & 6.2 & 2.12 & 2.44 & 6.83 & 2.41 & 58.63 & 27.00 & 20.06 & 2.15 & 13.93 \\
\hline Sink & 238.5 & 81.54 & 1.09 & 2.15 & 41.37 & 100.00 & 28.06 & 26.58 & 86.07 & 100.00 \\
\hline Total & 292.5 & 100.00 & 2.15 & & 100.00 & & 26.58 & & 100 & \\
\hline
\end{tabular}


Table II-2 Dolomite Flotation Rate Data Using 1.0 kg/t FA-12

\begin{tabular}{|c|c|c|c|c|c|c|c|c|c|c|}
\hline $\begin{array}{c}\text { Time } \\
(\mathrm{s})\end{array}$ & $\begin{array}{c}\mathrm{Wt} \\
(\mathrm{g})\end{array}$ & $\begin{array}{c}\mathrm{Wt} \\
(\%)\end{array}$ & $\begin{array}{c}\mathrm{MgO} \\
\text { Grade }(\%)\end{array}$ & $\begin{array}{c}\text { Cumulative } \\
\mathrm{MgO} \text { grade } \\
(\%)\end{array}$ & $\begin{array}{c}\mathrm{MgO} \\
\text { Recovery } \\
(\%)\end{array}$ & $\begin{array}{c}\text { Cumulative } \\
\mathrm{MgO} \\
\text { recovery } \\
(\%)\end{array}$ & $\begin{array}{c}\mathrm{P}_{2} \mathrm{O}_{5} \text { grade } \\
(\%)\end{array}$ & $\begin{array}{c}\text { Cumulative } \\
\mathrm{P}_{2} \mathrm{O}_{5} \text { grade } \\
(\%)\end{array}$ & $\begin{array}{c}\mathrm{P}_{2} \mathrm{O}_{5} \\
\text { recovery } \\
(\%)\end{array}$ & $\begin{array}{c}\text { Cumulative } \\
\mathrm{P}_{2} \mathrm{O}_{5} \\
\text { recovery } \\
(\%)\end{array}$ \\
\hline 15 & 9.9 & 3.39 & 10.89 & 10.89 & 17.16 & 17.16 & 13.56 & 13.56 & 1.73 & 1.73 \\
\hline 30 & 8.1 & 2.77 & 9.32 & 10.18 & 12.02 & 29.18 & 16.25 & 14.77 & 1.69 & 3.42 \\
\hline 60 & 14.1 & 4.83 & 7.14 & 8.85 & 16.03 & 45.20 & 19.73 & 16.95 & 3.58 & 7.01 \\
\hline 120 & 12.5 & 4.28 & 6.02 & 8.05 & 11.98 & 57.18 & 21.02 & 18.09 & 3.38 & 10.39 \\
\hline 180 & 13.2 & 4.52 & 4.77 & 7.30 & 10.02 & 67.20 & 23.24 & 19.27 & 3.95 & 14.34 \\
\hline 300 & 11.6 & 3.97 & 2.83 & 6.56 & 5.23 & 72.43 & 26.45 & 20.47 & 3.95 & 18.29 \\
\hline 350 & 7.4 & 2.53 & 1.65 & 6.08 & 1.94 & 74.37 & 28.01 & 21.19 & 2.67 & 20.96 \\
\hline Sink & 215.4 & 73.72 & 0.75 & 2.15 & 25.63 & 100.00 & 28.50 & 26.58 & 79.04 & 100.00 \\
\hline Total & 292.2 & 100.00 & 2.15 & & 100.00 & & 26.58 & & 100 & \\
\hline
\end{tabular}


Table II-3 Dolomite Flotation Rate Data Using 1.25 kg/t FA-12

\begin{tabular}{|c|c|c|c|c|c|c|c|c|c|c|}
\hline $\begin{array}{c}\text { Time } \\
(\mathrm{s})\end{array}$ & $\begin{array}{c}\mathrm{Wt} \\
(\mathrm{g})\end{array}$ & $\begin{array}{c}\mathrm{Wt} \\
(\%)\end{array}$ & $\begin{array}{c}\mathrm{MgO} \\
\text { Grade }(\%)\end{array}$ & $\begin{array}{c}\text { Cumulative } \\
\mathrm{MgO} \text { grade } \\
(\%)\end{array}$ & $\begin{array}{c}\mathrm{MgO} \\
\text { Recovery } \\
(\%)\end{array}$ & $\begin{array}{c}\text { Cumulative } \\
\mathrm{MgO} \\
\text { recovery } \\
(\%)\end{array}$ & $\begin{array}{c}\mathrm{P}_{2} \mathrm{O}_{5} \text { grade } \\
(\%)\end{array}$ & $\begin{array}{c}\text { Cumulative } \\
\mathrm{P}_{2} \mathrm{O}_{5} \text { grade } \\
(\%)\end{array}$ & $\begin{array}{c}\mathrm{P}_{2} \mathrm{O}_{5} \\
\text { recovery } \\
(\%)\end{array}$ & $\begin{array}{c}\text { Cumulative } \\
\mathrm{P}_{2} \mathrm{O}_{5} \\
\text { recovery } \\
(\%)\end{array}$ \\
\hline 15 & 11.6 & 3.96 & 10.55 & 10.55 & 19.45 & 19.45 & 14.22 & 14.22 & 2.12 & 2.12 \\
\hline 30 & 10.4 & 3.55 & 8.87 & 9.76 & 14.66 & 34.12 & 16.76 & 15.42 & 2.24 & 4.36 \\
\hline 60 & 15.9 & 5.43 & 7.14 & 8.66 & 18.05 & 52.16 & 19.81 & 17.26 & 4.05 & 8.41 \\
\hline 120 & 14.2 & 4.85 & 5.23 & 7.72 & 11.81 & 63.97 & 23.12 & 18.86 & 4.22 & 12.63 \\
\hline 180 & 16.2 & 5.54 & 3.14 & 6.64 & 8.09 & 72.05 & 25.47 & 20.43 & 5.31 & 17.94 \\
\hline 300 & 13.2 & 4.51 & 2.21 & 5.92 & 4.64 & 76.69 & 26.89 & 21.47 & 4.56 & 22.50 \\
\hline 350 & 8.7 & 2.97 & 1.43 & 5.49 & 1.98 & 78.67 & 27.98 & 22.10 & 3.13 & 25.63 \\
\hline Sink & 202.4 & 69.17 & 0.66 & 2.15 & 21.33 & 100.00 & 28.58 & 26.58 & 74.37 & 100.00 \\
\hline Total & 292.6 & 100.00 & 2.15 & & 100.00 & & 26.58 & & 100.00 & \\
\hline
\end{tabular}


Table II-4 Dolomite Flotation Rate Data Using 0.5 kg/t PA-31

\begin{tabular}{|c|c|c|c|c|c|c|c|c|c|c|}
\hline $\begin{array}{c}\text { Time } \\
(\mathrm{s})\end{array}$ & $\begin{array}{c}\mathrm{Wt} \\
(\mathrm{g})\end{array}$ & $\begin{array}{c}\mathrm{Wt} \\
(\%)\end{array}$ & $\begin{array}{c}\mathrm{MgO} \\
\text { Grade }(\%)\end{array}$ & $\begin{array}{c}\text { Cumulative } \\
\mathrm{MgO} \text { grade } \\
(\%)\end{array}$ & $\begin{array}{c}\mathrm{MgO} \\
\text { Recovery } \\
(\%)\end{array}$ & $\begin{array}{c}\text { Cumulative } \\
\mathrm{MgO} \\
\text { recovery } \\
(\%)\end{array}$ & $\begin{array}{c}\mathrm{P}_{2} \mathrm{O}_{5} \text { grade } \\
(\%)\end{array}$ & $\begin{array}{c}\text { Cumulative } \\
\mathrm{P}_{2} \mathrm{O}_{5} \text { grade } \\
(\%)\end{array}$ & $\begin{array}{c}\mathrm{P}_{2} \mathrm{O}_{5} \\
\text { recovery } \\
(\%)\end{array}$ & $\begin{array}{c}\text { Cumulative } \\
\mathrm{P}_{2} \mathrm{O}_{5} \\
\text { recovery } \\
(\%)\end{array}$ \\
\hline 15 & 4.9 & 1.68 & 13.21 & 13.21 & 10.34 & 10.34 & 10.33 & 10.33 & 0.65 & 0.65 \\
\hline 30 & 6.4 & 2.20 & 11.13 & 12.03 & 11.38 & 21.72 & 13.26 & 11.99 & 1.10 & 1.75 \\
\hline 60 & 8.3 & 2.85 & 10.09 & 11.21 & 13.38 & 35.10 & 14.98 & 13.26 & 1.61 & 3.36 \\
\hline 120 & 9.0 & 3.09 & 8.54 & 10.37 & 12.28 & 47.39 & 17.32 & 14.53 & 2.01 & 5.37 \\
\hline 180 & 8.5 & 2.92 & 6.63 & 9.51 & 9.00 & 56.39 & 20.85 & 15.98 & 2.29 & 7.66 \\
\hline 300 & 6.0 & 2.06 & 3.01 & 8.61 & 2.89 & 59.28 & 25.77 & 17.34 & 2.00 & 9.66 \\
\hline 350 & 5.5 & 1.89 & 1.88 & 7.85 & 1.65 & 60.93 & 27.69 & 18.52 & 1.97 & 11.63 \\
\hline Sink & 242.5 & 83.30 & 1.01 & 2.15 & 39.07 & 100.00 & 28.20 & 26.58 & 88.37 & 100.00 \\
\hline Total & 291.1 & 100.00 & 2.15 & & 100.00 & & 26.58 & & 100 & \\
\hline
\end{tabular}


Table II-5 Dolomite Flotation Rate Data Using 0.5 kg/t PA-31

\begin{tabular}{|c|c|c|c|c|c|c|c|c|c|c|}
\hline $\begin{array}{c}\text { Time } \\
(\mathrm{s})\end{array}$ & $\begin{array}{c}\mathrm{Wt} \\
(\mathrm{g})\end{array}$ & $\begin{array}{c}\mathrm{Wt} \\
(\%)\end{array}$ & $\begin{array}{c}\mathrm{MgO} \\
\text { Grade }(\%)\end{array}$ & $\begin{array}{c}\text { Cumulative } \\
\mathrm{MgO} \text { grade } \\
(\%)\end{array}$ & $\begin{array}{c}\mathrm{MgO} \\
\text { Recovery } \\
(\%)\end{array}$ & $\begin{array}{c}\text { Cumulative } \\
\mathrm{MgO} \\
\text { recovery } \\
(\%)\end{array}$ & $\begin{array}{c}\mathrm{P}_{2} \mathrm{O}_{5} \text { grade } \\
(\%)\end{array}$ & $\begin{array}{c}\text { Cumulative } \\
\mathrm{P}_{2} \mathrm{O}_{5} \text { grade } \\
(\%)\end{array}$ & $\begin{array}{c}\mathrm{P}_{2} \mathrm{O}_{5} \\
\text { recovery } \\
(\%)\end{array}$ & $\begin{array}{c}\text { Cumulative } \\
\mathrm{P}_{2} \mathrm{O}_{5} \\
\text { recovery } \\
(\%)\end{array}$ \\
\hline 15 & 6.2 & 2.11 & 12.47 & 12.47 & 12.22 & 12.22 & 10.84 & 10.84 & 0.86 & 0.86 \\
\hline 30 & 7.5 & 2.55 & 11.02 & 11.68 & 13.07 & 25.29 & 13.38 & 12.23 & 1.28 & 2.14 \\
\hline 60 & 8 & 2.72 & 9.84 & 11.00 & 12.45 & 37.73 & 15.55 & 13.45 & 1.59 & 3.73 \\
\hline 120 & 16.3 & 5.54 & 8.22 & 9.81 & 21.18 & 58.92 & 17.81 & 15.32 & 3.71 & 7.45 \\
\hline 180 & 12.8 & 4.35 & 5.87 & 8.82 & 11.88 & 70.80 & 22.06 & 17.02 & 3.61 & 11.06 \\
\hline 300 & 10.4 & 3.54 & 2.56 & 7.75 & 4.21 & 75.01 & 26.21 & 18.58 & 3.49 & 14.54 \\
\hline 350 & 8.7 & 2.96 & 1.42 & 6.96 & 1.95 & 76.96 & 27.87 & 19.74 & 3.10 & 17.64 \\
\hline Sink & 224.3 & 76.24 & 0.65 & 2.15 & 23.04 & 100.00 & 28.71 & 26.58 & 82.36 & 100.00 \\
\hline Total & 294.2 & 100.00 & 2.15 & & 100.00 & & 26.58 & & 100 & \\
\hline
\end{tabular}


Table II-6 Dolomite Flotation Rate Data Using 1.25 kg/t PA-31

\begin{tabular}{|c|c|c|c|c|c|c|c|c|c|c|}
\hline $\begin{array}{c}\text { Time } \\
(\mathrm{s})\end{array}$ & $\begin{array}{c}\mathrm{Wt} \\
(\mathrm{g})\end{array}$ & $\begin{array}{c}\mathrm{Wt} \\
(\%)\end{array}$ & $\begin{array}{c}\mathrm{MgO} \\
\text { Grade }(\%)\end{array}$ & $\begin{array}{c}\text { Cumulative } \\
\mathrm{MgO} \text { grade } \\
(\%)\end{array}$ & $\begin{array}{c}\mathrm{MgO} \\
\text { Recovery } \\
(\%)\end{array}$ & $\begin{array}{c}\text { Cumulative } \\
\mathrm{MgO} \\
\text { recovery } \\
(\%)\end{array}$ & $\begin{array}{c}\mathrm{P}_{2} \mathrm{O}_{5} \text { grade } \\
(\%)\end{array}$ & $\begin{array}{c}\text { Cumulative } \\
\mathrm{P}_{2} \mathrm{O}_{5} \text { grade } \\
(\%)\end{array}$ & $\begin{array}{c}\mathrm{P}_{2} \mathrm{O}_{5} \\
\text { recovery } \\
(\%)\end{array}$ & $\begin{array}{c}\text { Cumulative } \\
\mathrm{P}_{2} \mathrm{O}_{5} \\
\text { recovery } \\
(\%)\end{array}$ \\
\hline 15 & 12.6 & 4.27 & 11.21 & 11.21 & 22.25 & 22.25 & 12.94 & 12.94 & 2.08 & 2.08 \\
\hline 30 & 9.2 & 3.12 & 9.54 & 10.51 & 13.82 & 36.07 & 15.86 & 14.17 & 1.86 & 3.94 \\
\hline 60 & 12.1 & 4.10 & 7.44 & 9.41 & 14.18 & 50.25 & 18.52 & 15.72 & 2.86 & 6.79 \\
\hline 120 & 16.3 & 5.52 & 5.68 & 8.20 & 14.58 & 64.83 & 21.71 & 17.67 & 4.51 & 11.30 \\
\hline 180 & 18.3 & 6.20 & 3.23 & 6.87 & 9.31 & 74.14 & 24.45 & 19.48 & 5.70 & 17.00 \\
\hline 300 & 9.8 & 3.32 & 1.71 & 6.23 & 2.64 & 76.78 & 27.21 & 20.45 & 3.40 & 20.40 \\
\hline 350 & 6.7 & 2.27 & 1.32 & 5.84 & 1.39 & 78.18 & 27.97 & 21.04 & 2.39 & 22.79 \\
\hline Sink & 210.3 & 71.22 & 0.66 & 2.15 & 21.82 & 100.00 & 28.82 & 26.58 & 77.21 & 100.00 \\
\hline Total & 295.3 & 100.00 & 2.15 & & 100.00 & & 26.58 & & 100.00 & \\
\hline
\end{tabular}




\section{VITA}

Zhengxing Gu was born on September 11, 1956 in Jianhu, Jiangsu, the People's Republic of China. Mr. Gu received his secondary education at Xingqiao Middle School and Yanhe High School from 1969 to 1974 in Jianhu, Jiangsu. He received his Bachelor of Science Degree in mineral engineering from Central-South University of Technology (CSUT) in July 1982. After graduated from CSUT, he worked with Lianyungang Design and Research Institute as a research engineer from 1982 to 1992, and a senior engineer from 1992 to 1999 involved in the research and development of fertilizer-related mineral projects such as phosphate, pyrite, potash, etc. From April 1985 to May 1986, he worked as a visiting engineer in the field of mineral processing at Tennessee Valley Authority, International Fertilizer Development Center and Columbia University.

On January 3, 2000, Mr. Gu enrolled in the Master of Science program at the Department of Mining Engineering, West Virginia University, Morgantown, West Virginia. Currently he is a candidate of Master of Science Degree.

Mr. Gu married to Xiaomei Wang in 1995 in Lianyungang, Jiangsu, China. They have a sixteen-year-old daughter, Jie Gu. 